\title{
The National Geographic Names Data Base: Phase II Instructions
}

Open File Report 84-036

1984 


\section{UNITED STATES \\ DEPARTMENT OF THE INTERIOR \\ U.S. GEOLOGICAL SURVEY}

THE NATIONAL GEOGRAPHIC NAMES

DATA BASE: PHASE II INSTRUCTIONS

By Donald J. Orth

and

Roger L. Payne

Open File Report $84-036$

Reston, Virginia

1984 
First printing 1984

Reprinted 1984 


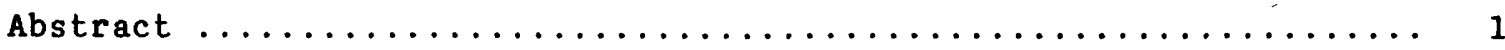

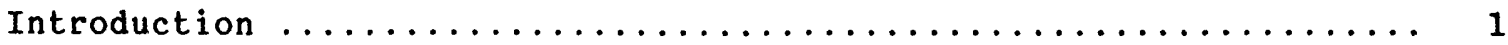

The National Geographic Names Data Base ................ 2

Basic record information .......................... 2

Building the data base $\ldots \ldots \ldots \ldots \ldots \ldots \ldots \ldots \ldots \ldots \ldots \ldots \ldots$

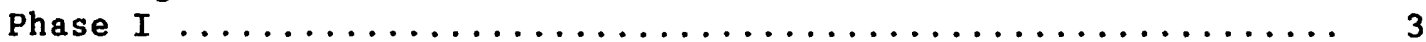

Phase II, Part 1: Collection and annotation of data .......... 7

General procedures ............................. 7

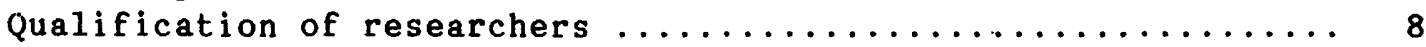

Part 1: Preparation ............................. 8

Acquiring work maps and other reference tools ......... 8

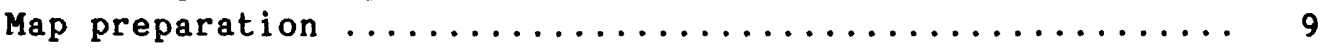

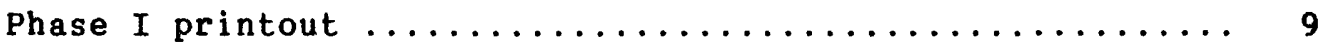

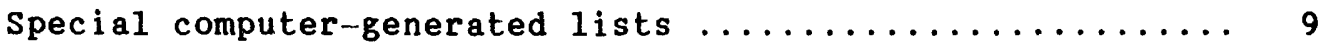

Bibliography and bibliographic codes $\ldots \ldots \ldots \ldots \ldots \ldots \ldots \ldots \ldots \ldots$

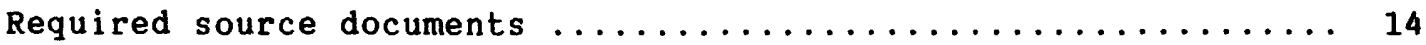

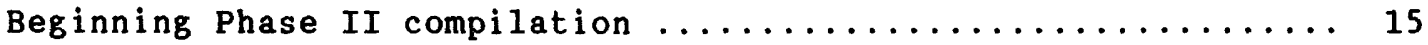

Four conditions to be researched ................. 15

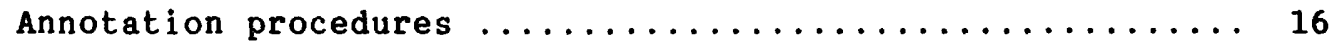

Name categories exempt from annotation .............. 19

Topographic map "Time-Gap" procedures ............... 19

County-level and minor civil division names .......... 20

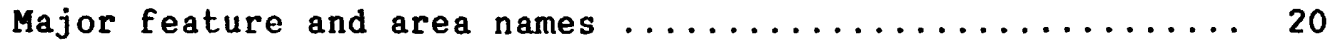

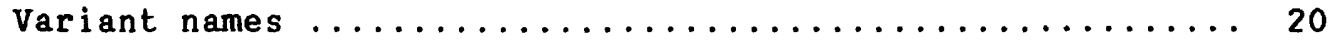

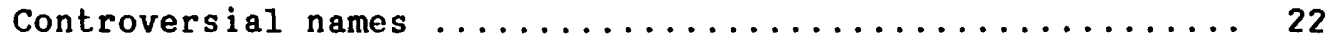

Vague, obsolete, and vanished entity names ........... 22

Information sources ................................ 25

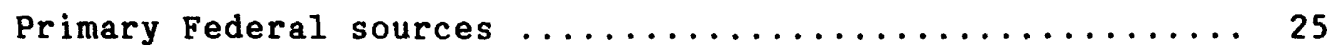

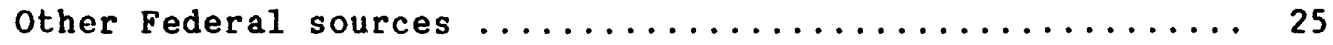

State and other related sources ................... 26

Historical and other publications and records ......... 26

Phase II, Part 2: Encoding preparation $\ldots \ldots \ldots \ldots \ldots \ldots \ldots \ldots \ldots \ldots$

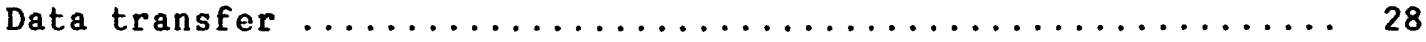

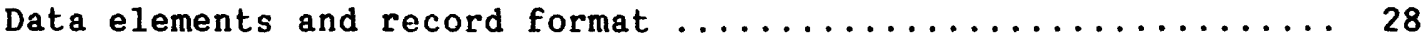

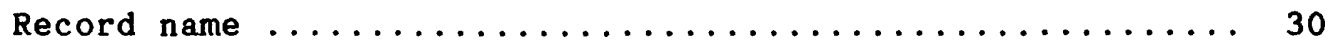

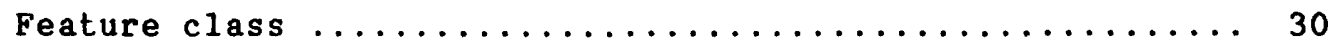

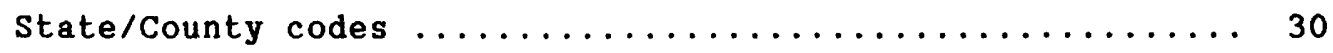

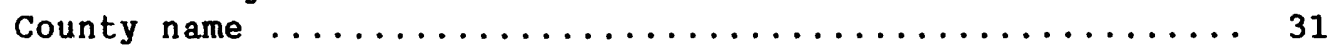

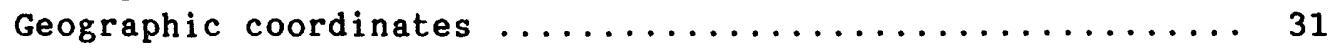

Source coordinate ......................... 33

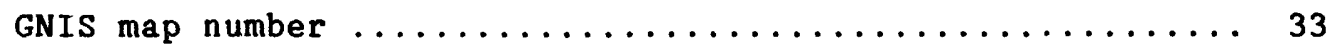

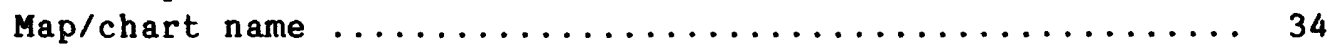

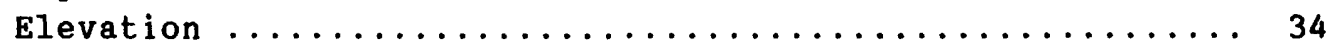

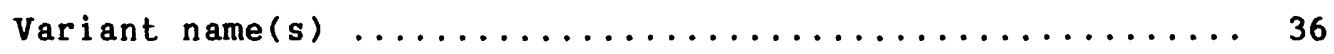

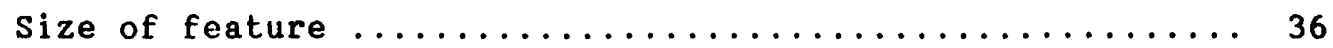

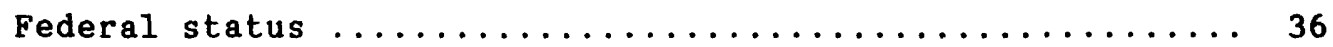

Special designators ................................ 37

Section, Township, Range, and Meridian ........... 37

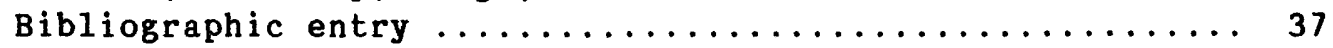

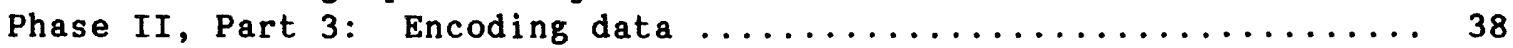

Appendix A: Geographic Names Information System categories of named features not yet included .................. 39 
Appendix B: Checklist of sources ................... 40

C: USGS topographic map preparation and instructions .... 41

D: Status category classification ............... 42

E: Glossary of feature class terms ............... 43

F: Standard cartographic abbreviations ............. 46

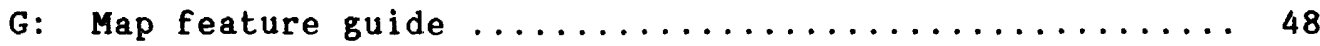

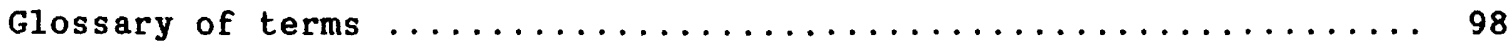

\section{ILLUSTRATIONS}

Page

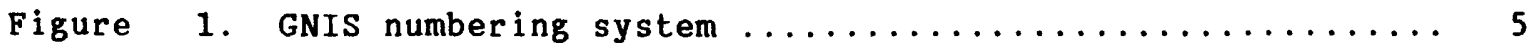

2. Sample State Index of large..scale topographic maps .... 10

3. Example of work map preparation showing FIPS county codes and map-cell code .................... 11

4. The use of drawn "tick" lines for determining latitude and longitude with a 10 -space divider ........... 12

5. Sample of the Phase I printout ................. 13

6. Map face annotations and feature delineation ......... 17

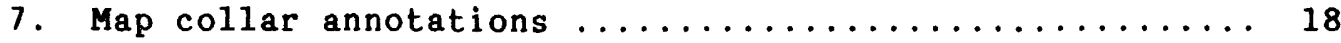

8. Identifying major named entities ............... 21

9. Application problems and variant names $\ldots \ldots \ldots \ldots \ldots \ldots 23$

10. Domestic geographic name report ................ 24

11. Annotating named Federal and state entities ......... 27

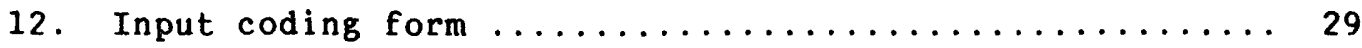

13. Generic information form .................... 32

14. Identifying stream/valley heads $\ldots \ldots \ldots \ldots \ldots \ldots \ldots \ldots$ 
THE NATIONAL GEOGRAPHIC NAMES

DATA BASE: PHASE II INSTRUCTIONS

By Donald J. Orth

and

Roger L. Payne

U.S. Geological Survey

523 National Center

Reston, Virginia 22092

\begin{abstract}
The Geographic Names Information System (GNIS) is a computer-based information system developed to meet major national needs by providing information for named entities in the United states and its territories. The National Geographic Names Data Base currently reflects most names and associated information recorded on the 1:24,000-scale (or largest scale available) topographic maps of the U.S. Geological Survey. The initial compilation, development, and editing of the National Geographic Names Data Base is termed Phase I. Optimal use and effectiveness of GNIS requires that the names of features not recorded on topographic maps be added. The systematic collection of names from other sources, including maps, charts, and texts, is termed Phase II. In addition, specific types of features not compiled during Phase I will be encoded and added to the data base. Other names of importance to researchers and users, such as historical and variant names will also be in included. The rules and procedures for Phase II research, compilation, and encoding are contained in this paper.
\end{abstract}

\title{
INTRODUCTION
}

Since about 1960 there have been growing demands for a relatively complete 1 isting of our Nation's named places, features, and areas. From about 1955 to 1970 , at least 135 attempts, costing several million dollars, were made by various Federal and State agencies and business organizations to develop a computer-based geographic names data base designed to meet a variety of special needs. For the most part, these attempts were limited in completeness of name coverage and extent of name information. A single, unbiased, relatively complete depository of geographic names, including basic or essential information about each name and named place, was urgently needed by all levels of government and diverse users in private industry. The U.S. Board on Geographic Names (BGN) was also interested because such an information depository would facilitate the standardization of U.S. geographic names. Because of the nature and size of the task, most users looked to the Federal Government for help in developing and maintaining a master computer-based catalog of the Nation's 3 to 5 million domestic geographic names. The U.S. Geological Survey (USGS) agreed in 1979 to undertake such a program. The Geological survey was interested because it is responsible for providing staff support for the domestic names activities of the Board and such a program would provide direct support to its mapping missions. 


\title{
The National Geographic Names Data Base
}

A relatively complete computerized data base of geographic names in the United states and its territories was planned by USGS as early as 1960 . Although the survey has been developing and using automated methods for handling geographic name information since 1964 , it was not until computer technology was readily available that building such a data base became feasible. An early version of the National Geographic Names Data Base was developed in 1975. Further development led to implementation of a system called the Geographic Names Information system (GNIS). The System is made up of five data bases, data retrieval software, ancillary software, and procedures specifically designed, arranged, and programmed to function as a geographic names information system and a tool for toponymic research. GNIS is a computer-based system designed to meet a broad spectrum of information and program needs, including:

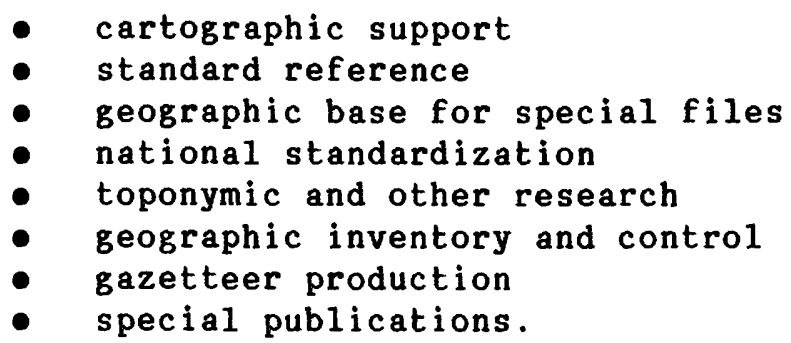

Information in the system may be retrieved, arranged, analyzed, and manipulated for general and specific purposes without bias. The National Geographic Names Data Base is the largest data base in the GNIS and contains a separate file for each state and territory. The other data bases in GNIS are:

- National Topographic Map Names Data Base

- Generic Data Base

- Board on Geographic Names Data Base

- National Atlas Data Base.

Information about GNIS and its products and the National Geographic Names Data Base may be obtained from:

\author{
GNIS Manager \\ U.S. Geological Survey \\ National Center 523 \\ Reston, Virginia 22092 \\ Tel: 703-860-6261 (FTS 928-6261).
}

\section{Basic Record Information}

The effectiveness of GNIS and the National Geographic Names Data Base depends on both the completeness and integrity of the data in the system. The geographic-names staff have identified those basic or critical elements needed for each name record in the system. These critical elements are: 
1. Written form of the full official, legal, or standard name (Record Name),

2. Designation of the kind of geographic entity by a standard term (Feature Class),

3. Location by State and county (State/County Name and code),

4. Location by map of a standard series (Map/Chart Name and codes),

5. Identification and extent of the named entity by geographic coordinates (Geographic Coordinates),

6. Official status of the name and its application (Federal status),

7. Variant names or other names for the same geographical entity (Variant Names),

8. Ownership or administrative areas (special designators), and

9. Bibliography.

Although not critical, three other elements are considered important for a name record when applicable:

1. Elevation,

2. Size, and

3. Section, township, range, and principal meridian.

See Data Elements and Record Format for a description of each of the primary data elements associated with a name record.

\section{Building the Data Base}

Building the data base for handling information and defining required data elements is necessary. The major task, however, was and is the collection of names and associated information to go into the data base. Written sources of name information are extensive and varied. The sources include both current and historical maps and charts as well as textual material that vary in number and form from area to area. Only published name information was considered for building the data base at this time.

There is no question that the largest and most uniformly distributed coverage of current geographic names of the United States and its territories is found on the topographic maps published by USGS. A survey made in 1970 indicated that the large- and intermediate-scale topographic maps contained from 50 to 70 percent of all names in current usage.

This situation provided a logical division of the work into two distinct phases:

- Phase I, the collection of names and associated information from the USGS standard topographic map series, and

- Phase II, the collection of such information from other sources.

\section{Phase I}

The Geological Survey began preliminary work on Phase I in 1976, a time when published large-scale topographic maps covered more than 70 percent of this country's land surface. In a pilot project names published 
on the maps covering the States of Kansas and Colorado were collected and recorded in machine-readable form. In the fall of 1978 , a contract was awarded to collect and record corresponding information for the remainder of the states and territories. The contract was completed in January 1981. A11 work was monitored closely for completeness, accuracy, and adherence to established procedures by the Branch of Geographic Names in the Geological Survey's National Mapping Division. The error rate was about 2 percent.

Phase I activity for building the data base involved:

- The systematic collection of most names and attendent information from the topographic maps on a state-by-state basis, and

- The correction and updating of this data by comparison with the official BGN files by the National Mapping Division's Branch of Geographic Names staff.

The procedures followed for Phase I were as follows:

- Map Acquisition and Numbering

A complete collection of USGS topographic maps was acquired on a State-by-State basis. Each $7.5 \times 7.5$-minute map or unpublished map cell of a state set was given a unique sequential number. Beginning with " 1 " in the northwest corner of the state, the numbering proceeds from west to east while moving south latitudinally (fig. 1). The largest-scale USGS topographic maps available in each state were used for compilation.

- Map Annotation

The contractor identified each named place and feature on every map and assigned each a unique number. The extent of certain features such as streams also was annotated. Each named feature was identified on each topographic map on which the feature appeared whether or not it was named on the map.

- Data Entry

The four corners of the map were recorded for purposes of electronically digitizing the geographic coordinates and the location of each feature was digitized and stored on magnetic disk along with other required data, such as name, designator, county code, map code, and elevation. The digitized $x-y$ coordinates were converted automatically into geographic coordinates before being entered into the data base.

- Processing and Editing

A series of programs was used to check the accuracy of data during compilation and which sorted the information into a required record format on tape.

- Format Conversion

Tapes produced by the contractor were delivered to USGS in a specific format, designed for fast and efficient keying of data. The data were then entered into the GNIS.

- Data Monitoring

Names data from a random sampling of 10 percent of the $1: 24,000-$ scale maps were retrieved from the system in printout form for data verification. The names and feature positions also were plotted on transparent overlays for visual comparison with the source maps. 


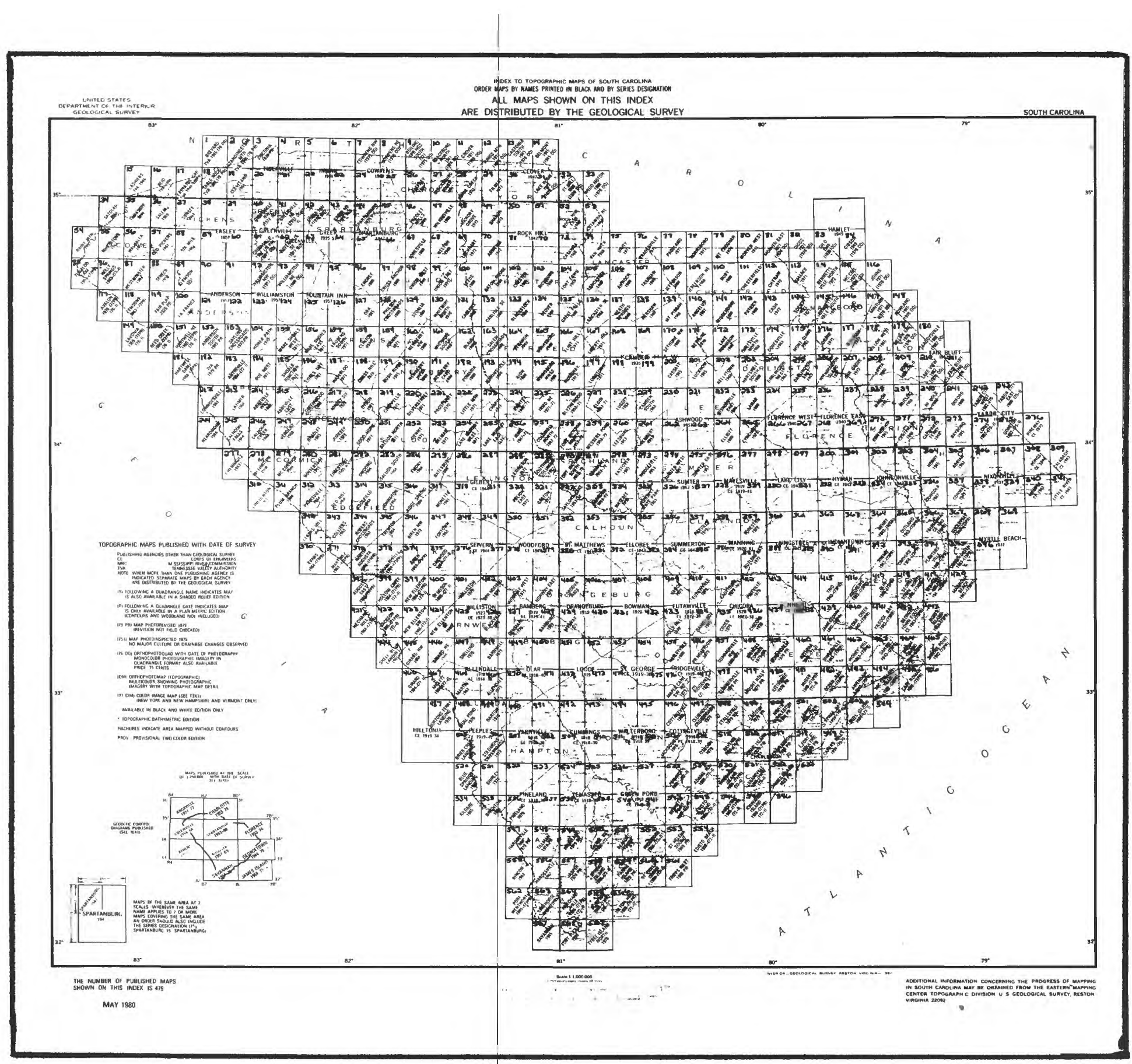

Figure 1.--Geographic Names Information system (GNIS) numbering system for South Carolina. 
- Editing and Updating

Data were checked against the BGN files and updated to include changes, additions, and corrections that occurred since the topographic maps were published. The Board's decision dates and variant names were added.

Phase I work resulted in the collection and storage of about 1.7 million name records. As soon as each state was completed, preliminary information was made available to users by means of spiral-bound alphabetical lists, special printouts, computer tapes, and microfiche. Also, the data base was made available at USGS for interactive retrieval, manipulation, arranging, and analysis of name information. 


\section{PHASE II, PART 1: COLLECTION AND ANNOTATION OF DATA}

Phase II work began in 1982. It is divided into three parts for convenience and control:

- Part 1, collection and annotation of data

- Part 2, transfer of data to coding forms

- Part 3, encoding data for entry into the system

A cooperator working with USGS may complete Parts $1 ; 1$ and 2 ; or 1,2 , and

3 for a state or part of a state depending on available resources.

The main thrust of Phase II work for each state project consists of a systematic search of selected documents to create new name records to add to those created during Phase $I$ and to collect variant names for all name records. This work must be completed before a state or territory volume of the "National Gazetteer of the United States of America" can be published.

Phase I compilation did not include all named entities shown on the topographic maps. For example, certain kinds of named features that were large or scattered could be handled more efficiently during later compilation or the information was already compiled and could be found on special lists or in digital form. Phase II, Part 1 compilation requires coding those name records omitted from phase $I$ compilation and researching and recording names and associated information not found on the topographic maps.

The topographic maps do not show all geographic names that are in current use. Many names in local and (or) published usage were unknown to the compilers when the maps were made. Names applied to minor features often were not shown for lack of map symbols or to avoid map clutter. The maps also do not normally show historical and obsolete names, variant applications, and other names once used for currently named places, features, or areas.

\section{General Procedures}

The following procedures are specified for the collection and processing of name data during Phase II, Part 1 work. These standard procedures help ensure the relative completeness and integrity of information in the National Geographic Names Data Base.

Phase II, Part 1 activity begins with the systematic review of name source documents other than topographic maps and the annotation of the new name information on a set of topographic work maps. The printed and annotated data on the maps are then used to create new name records which are encoded and added to the data base. Work must be accomplished in a specific order and carefully controlled to prevent duplication and to maintain accuracy of the data. The procedures for Part 1 are divided into:

- Preparation and

- Document review and map annotation. 


\section{Qualification of Researchers}

It is important that each person researching name information for Phase II be able to interpret topographic maps and to relate point, line, and area symbols among maps of different and varying scales. A researcher should be able to make reliable judgements on feature identification when comparing maps and relating textual description to map symbols. This includes expertise in translating named symbols on sketch maps for accurate identification on the modern large-scale topographic maps.

An understanding of how people use and apply geographic names to the landscape is useful. The researcher should understand how proper names are applied to symbols by map editors and the limitations inherent in the process. Knowledge of the geography and history of the area being worked will greatly improve a researcher's ability to interpret data. An important factor, of ten overlooked, is the researcher's ability to print upper and lower case letters legibly, and to print exactly what is intended because the person keying data will make no interpretation, but will enter exactly what is shown on the coding form.

\section{Part 1: Preparation}

Before beginning, decisions need to be made concerning administrative organization for the project, choice of persons who will do the work, limits of source-material investigation, and a work plan to be followed to achieve Phase II goals. The project needs a leader who can prepare reports and make decisions. The project requires careful direction to prevent duplication and omission, to maintain the integrity of the work, and to insure that the research workers have adequate work-map coverage and that they are aware of and can locate source documents.

Preparation also includes:

- Acquiring a set of work maps and other reference materials,

- Preparing the work maps,

- Acquiring a Phase I computer printout for reference,

- Acquiring selected computer-generated lists,

- Identifying, listing, and coding source documents.

A computer terminal for interactive access to GNIS is useful.

\section{Acquiring Work Maps and Other Reference Tools}

One of the first steps to be made is the acquisition of a master set of work maps. These should be the largest-scale topographic maps available. For the most part, they will be $1: 24,000$ - or 1:25,000-scale maps published by USGS. The next smallest scale, or 31,680 or $1: 62,500$, should be obtained for those areas not covered by the larger-scale maps. See figure 2 for a sample state index of large-scale topographic map coverage. A master set of work maps will be furnished by the GNIS Manager for an official Phase II cooperative program. Complete map coverage of the state at 1:250,000-scale and a state base map will also be furnished. Other reference items that will be furnished by USGS, if needed or when appropriate, include: 
- Federal Information Processing Standard publication, 1976 (FIPS PUB 6-2),

- List of Required and Suggested Source Documents,

- GNIS Users Guide

- Map Feature Guide

- List of State Civil Divisions,

- State Index of GNIS Map Codes, and

- National Ocean Service charts and National Forest maps.

\section{Map Preparation}

Map preparation helps to ensure maximum work efficiency with the minimum possibility of error. Preparation includes:

- Outlining all county boundaries with a felt-tipped marker of a specific color,

- Annotating state and county FIPS codes on each map collar adjacent to each county area ( $f i g .3$ ),

- Annotating GNIS map cell codes on the lower left corner of each map (in areas not covered by $1: 24,000$ - or $1: 25,000-$ scale maps, the individual $7.5 \times 7.5$-minute cells are identified and appropriately labeled on the smaller-scale map), and

- Drawing latitude and longitude lines across each map at the 2.5-minute "ticks" located at the neatline of each map, if geographic coordinates are to be obtained by the use of ten-space dividers (fig. 4).

Phase I Printout

The Phase I printout lists name records alphabetically by state or other area (fig. 5). The printout should be available as a reference for Phase II work. It is the only printed document that will tell the researcher whether a name record is already in the data base and what information is associated with the record. Researchers, however, should use the topographic maps for their main reference. Constant checking of the Phase I printout has been found to be uneconomic. If one has interactive access to GNIS, questions may be answered by direct retrieval of information.

\section{Special Computer-Generated Lists}

The Geological Survey'will furnish selected computer-generated feature listings. Name records for certain kinds of features were not created during Phase I work because the information was already available in more complete form in existing specialized data files. These features are:

\footnotetext{
- Airports,

- Radio and television antenna sites, and

- Recreation and wilderness areas.
} 


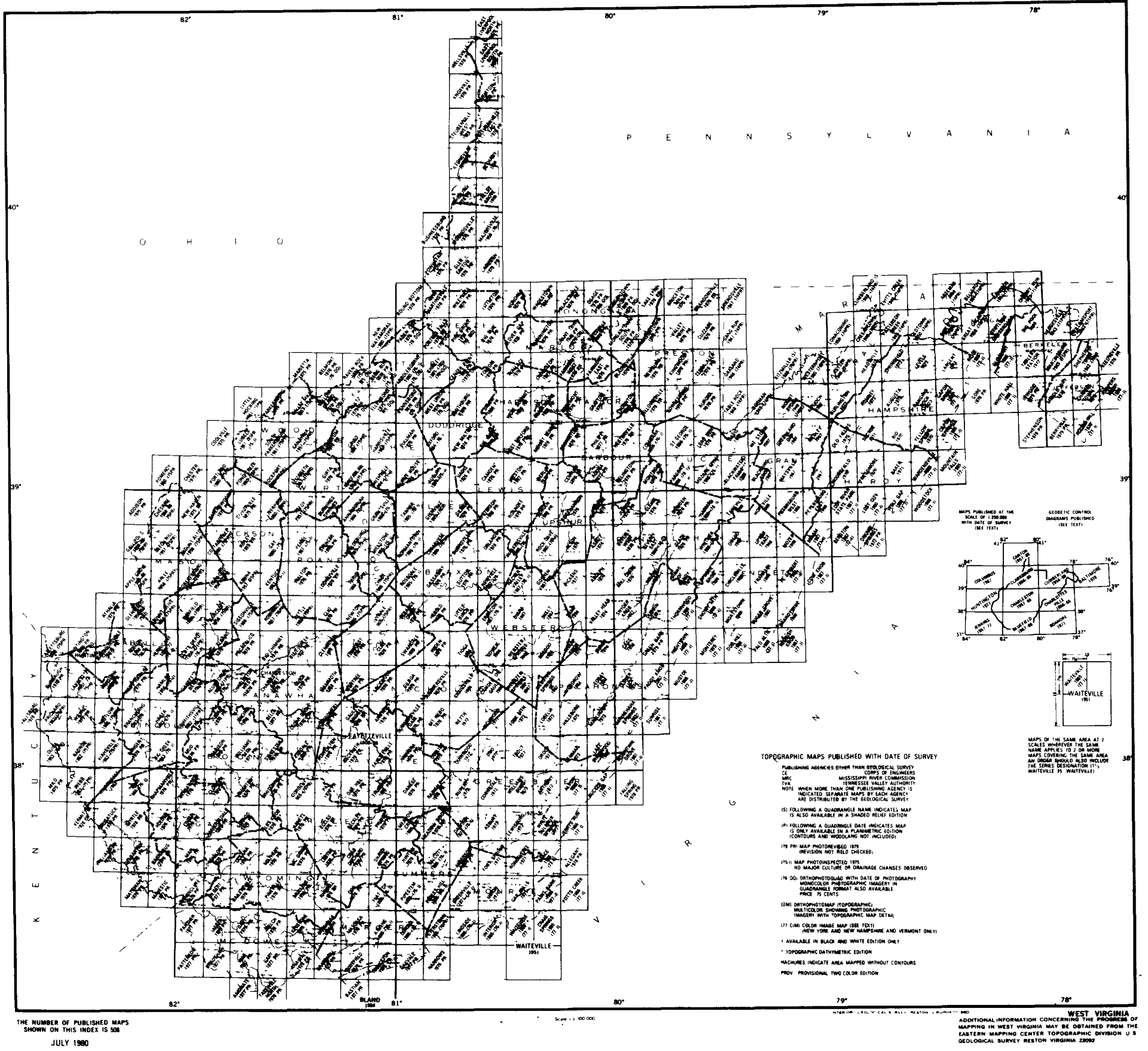

Figure 2.--The West Virginia Map Index published by the U.S. Geological Survey and made available to the public without charge. Most Map Indexes cover only one state. 


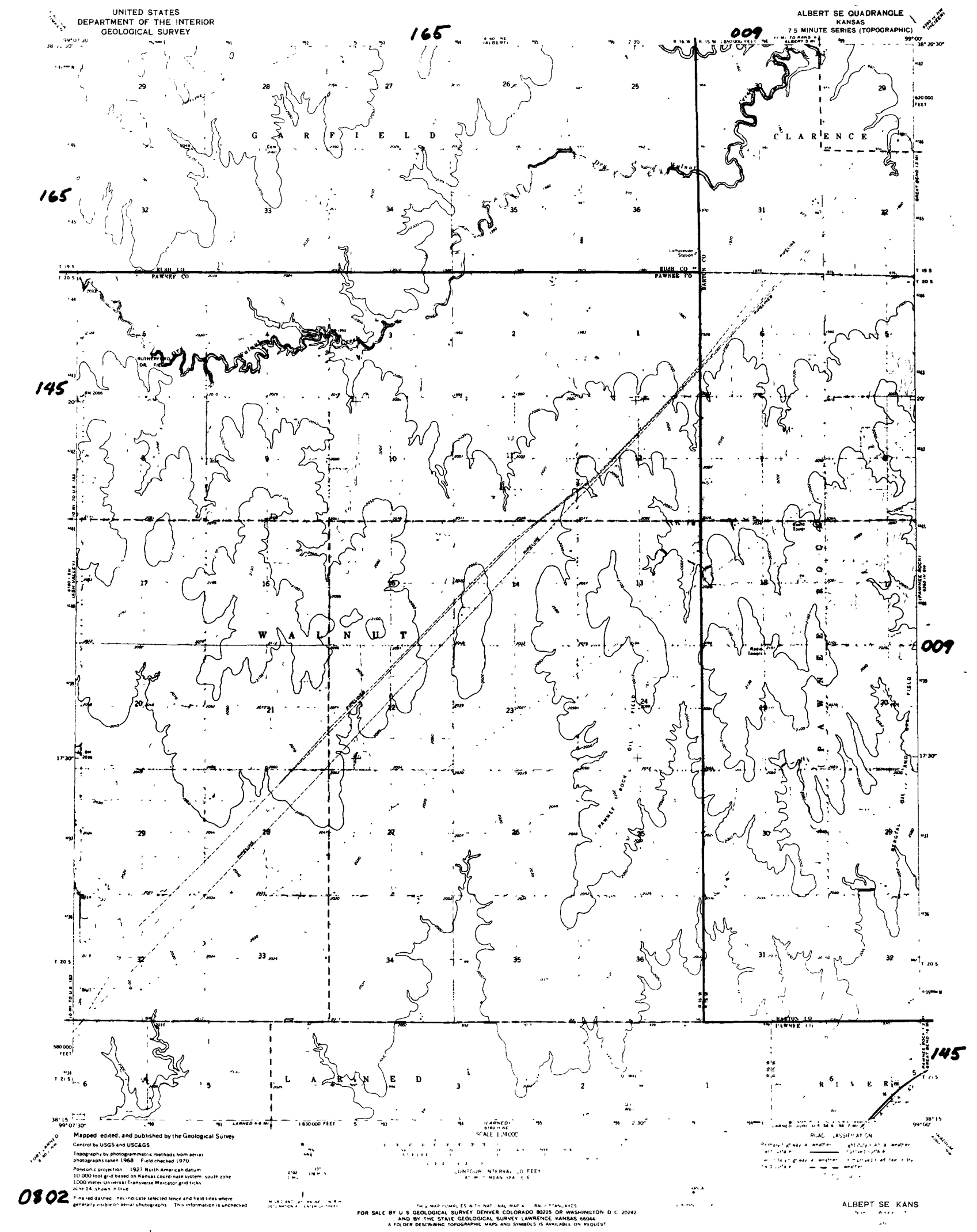

Figure 3.--An example of work preparation showing the annotated FIPS county codes and the map-cell code on the collar of the map. The county boundaries have been manually enhanced with a felt-tip pen for easier reading. 


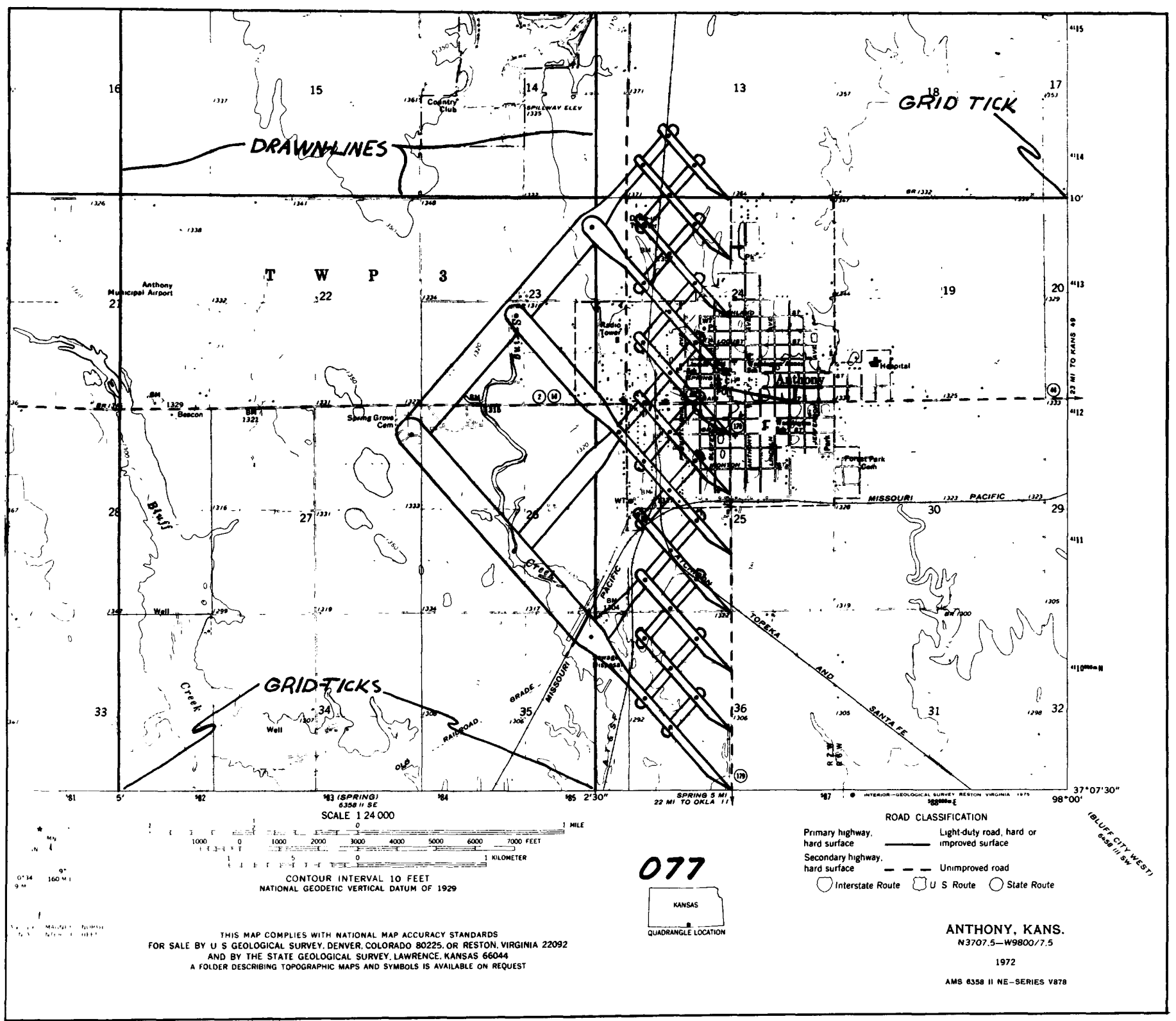

Figure 4.--Use of the equal spacing divider for determining latitude and longitude. The geographic coordinate system is indicated on the $1: 24,000$ - and $1: 25,000$-scale maps of the U.S. Geological Survey by grid ticks located along the neatline of each map 2.5 minutes apart. These grid ticks can be connected across the face of the work map by east-west and north-south lines. When the equal spacing divider is adjusted with its end points set at the sides of the 2.5-minute area, the distance between each point represents 15 seconds of latitude or longitude on the map. For example, there are 6.7 divider intervals counting from the bottom of the map at $37^{\circ} 07^{\prime} 30^{\prime \prime} \mathrm{N}+(6.7 \mathrm{x}$ 15") $11^{\prime 4}$ " (rounded) $=37^{\circ} 09^{\prime} 10^{\prime \prime} \mathrm{N}$. The longitude of Anthony is determined in the same manner east-west: $98^{\circ} 01^{\prime} 50^{\prime \prime} \mathrm{W}$. 
NAME - DRIFTWOOD TOWNSHIP

TYPE OF FEATURE - CIVIL

STATE/COUNTY FIPS CODE - 20153

GNIS MAP NO - 000815170009151800091519

GEOGRAPHIC COORDINATES - 395720N1010331W 395745N1010852W 400005N1010852W $400005 \mathrm{~N} 1010331 \mathrm{~W} 395705 \mathrm{~N} 1005855 \mathrm{~W} 400005 \mathrm{NM} 1005855 \mathrm{~W}$

ID NUMBER - 20009682

NAME - DRINKWATER CEMETERY

TYPE OF FEATURE - CEM

STATE/COUNTY FIPS CODE - 20017

GNIS MAP NO - 0820

GEOGRAPHIC COORDINATES -381543 NO964925W

ID NUMBER - 20007566

NAME - DRISCOLL OIL AND GAS FIELD

TYPE OF FEATURE - OILFIELD

STATE/COUNTY FIPS CODE - 20167

GNIS MAP NO - 0623

GEOGRAPHIC COORDINATES - 384332NO983600W

ID NUMBER - 20000450

NAYE - DRUA CREEK

TYPE OF PEATURE - STREAY

STATE/COUNTY FIPS CODE - 201252009920133

GNIS MAP NO - $\begin{array}{llll}1379 & 1378 & 1318 & 1257\end{array}$

GEOGRAPHIC COORDINATES - 371146N0953751W 371400N0953600W 371750NO953450W SOURCE OF FEATURE (LATLONG) - 372647N0953008W

Figure 5.--Sample record entries from Phase I computer printout. 
Other categories of names are incomplete and will require comparison with more complete lists. These categories are:

- Dams and reservoirs, and

- Populated places (FIPS 55).

\section{Bibliography and Bibliographic Codes}

A bibliography and bibliographic coding procedure is built into the Geographic Names Information System. This allows a ready reference to the sources of all names. The absence of a code indicates that the source of the name in the data base is a topographic map published by USGS prior to the initial compilation period of 1978-1981 (see p. 31 for coding topographic maps published after Phase I work). Preparation for Phase II work requires developing a preliminary bibliography of required and probable source documents to be reviewed. The bibliographic listing will grow as new sources are discovered.

With the exception of the USGS topographic maps reviewed during Phase I compilation, each source document is given a unique alphanumeric code. The first two characters of the code are the alphabetical FIPS state code, followed by a dash $(-)$, then the letter $T$ (for a textual source) or an $M$ (for a map source), and unique number used for referencing the different sources. The unique number may be assigned sequentially as the source bibliography is developed for the maps (M) and texts (T). Bibliographic codes are annotated on the work maps for both new name data and variant names. Examples: ME-T1, ME-T2, ME-T3, etc. and ME-M1, ME-M2, ME-M3, etc. (Maine bibliographic codes).

If the document source is an atlas or similar publication, the map or page number should be recorded as part of the bibliographic code. The map or page number is separated from the code by a slash (/). Examples:

AZ-T2/p. 80, AZ-M14/m. 24 (Arizona codes).

An annotated bibliography for each source from which a name or variant name was derived should be prepared in a standard format along with its bibliographic code:

AZ-T16 Johnson, Robert X. "Hiking Guide to the Rocky Mountains," New York: Doubleday, Inc., 1982, 3rd Ed., 472 pp. Refers to hiking routes with references to names of trails and physical features.

A copy of the annotated bibliography must be submitted periodically to the GNIS Manager for documentation.

\section{Required Source Documents}

A major part of Phase II work requires the review of certain important source documents. Documents should be reviewed in the following order:

* USGS Topographic maps published or reprinted since Phase I compilation (the key date will be provided by the GNIS Manager);

* National ocean Service coast charts, river charts, and lake charts; 


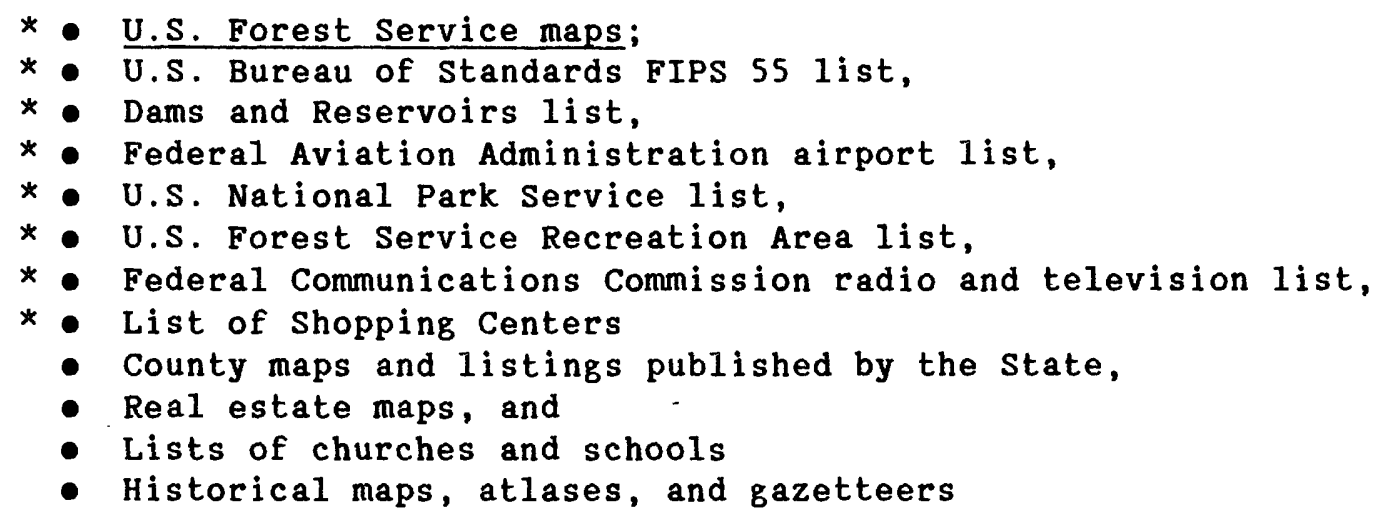

* Source documents are furnished by the GNIS Manager.

Note - Underlined sources are considered basic references for determining official standard names.

\section{Beginning Phase II Compilation}

In review, the purpose of Phase II, Part I research is to review and collect specific geographic-name data not collected during Phase I compilation from a select variety of source documents. Use of a single set of work maps for Phase II compilation is crucial to a successful program for several reasons. These large-scale topographic maps provide a graphic representation of selected natural and manmade entities on the Earth's surface plotted to a definite scale. Portrayal of the shape and elevation of the terrain is determined by precise engineering surveys and measurements. The scales of the work maps are large enough to allow symbolism and name labeling of relatively small features. Because each work map shows the accurate locations and shapes of mountains, valleys, and levels, the networks of streams, bodies of water, and principal works of man, it is easy to relate a name with the entity it identifies. If an appropriate symbol is not shown on the map for a particular named entity, a symbol can be easily annotated directly onto the map in a fairly accurate location by relating position with other map symbols. New names and additional variant names are associated with the proper map symbols and annotated directly onto the maps along with bibliographic codes and other pertinent data. Both the annotated data and reliable qualitative and quantitative information published on the maps are used to develop new name records for the National Geographic Names Data Base.

\section{Four Conditions to be Researched}

Each source document must be systematically reviewed and compared with the work maps. One source document normally is reviewed at a time in order to prevent duplication and error. If more than one is reviewed at a time by several persons working on the project, care should be taken to prevent duplication of work. Only one reference is needed for a Phase II name record. The following four conditions between the source documents and the work maps are identified if encountered: 
- Names in the source documents applied to geographical entities not named on the work maps (New Name),

- Different names or different spellings for the same entity (Variant Name),

- Names with the same or different spelling applied to two different entities of the same kind (Variant Application), and

- names with the same or different spelling applied in part to two different entities of the same kind.

\section{Annotation Procedures}

The name data, including bibliographic code, for these four conditions are annotated on the work maps, associated with the appropriate feature symbols. Annotations on the work maps should be made so that there is no ambiguity with regard to the names and their applications. The names and their symbols on the work maps should not be obscured by the annotations.

Work maps may be annotated either at or alongside the map symbols on the face of the map ( $\mathrm{fig} .6$ ) or on the map collar with connecting lines to the appropriate symbols (fig. 7). The researcher must define the extent of named features. This is done by annotating their limits or extents with pencil, pen, or different color markers on the work maps (fig. 7).

Transferring name information from the various source documents should be done carefully. Print names in upper and lower case letters exactly as found on the source document.

When possible, all parts of a name abbreviated on the source document should be spelled out when annotated on the work map (see Appendix F, Standard Cartographic Abbreviations, p. 46). For example, "St. Johns R." applied to a stream is annotated "Saint Johns River" on the work map. Crowding on the work map, however, may occasionally restrict this procedure. If it is necessary to use abbreviations, they should be printed in the standard form and used only for the generic part of the name. When necessary, exceptions may be made for the specific part of names involving directions (North, East, Southwest, etc.) and the words Fort (Ft.), Saint (St.), Sainte (Ste.), Right (R.), Left (L.).

Arabic numbers in names should be spelled out. Roman numerals should be retained because they are based on the letters of the Roman alphabet.

Geographic coordinates are established not only to locate named places, features, and areas, but also to indicate the extent of certain kinds of features and to identify all map cells on which a named entity is located. The coordinates are categorized into primary, secondary, and source coordinates in order to establish coordinate priorities and to indicate locations of parts of some entities, such as the mouths and heads of streams, canyons, valleys, and washes. The annotation symbol to be used on the work maps are:

$$
\begin{aligned}
& * \quad \text { primary coordinate } \\
& \mathbf{x}=\text { secondary coordinate } \\
& 0=\text { source coordinate. }
\end{aligned}
$$

More complete instructions as to the locations where geographical coordinates are to be taken are found on pages 52-55 of these guidelines and in the Map Feature Guide (Appendix G, p. 48). 


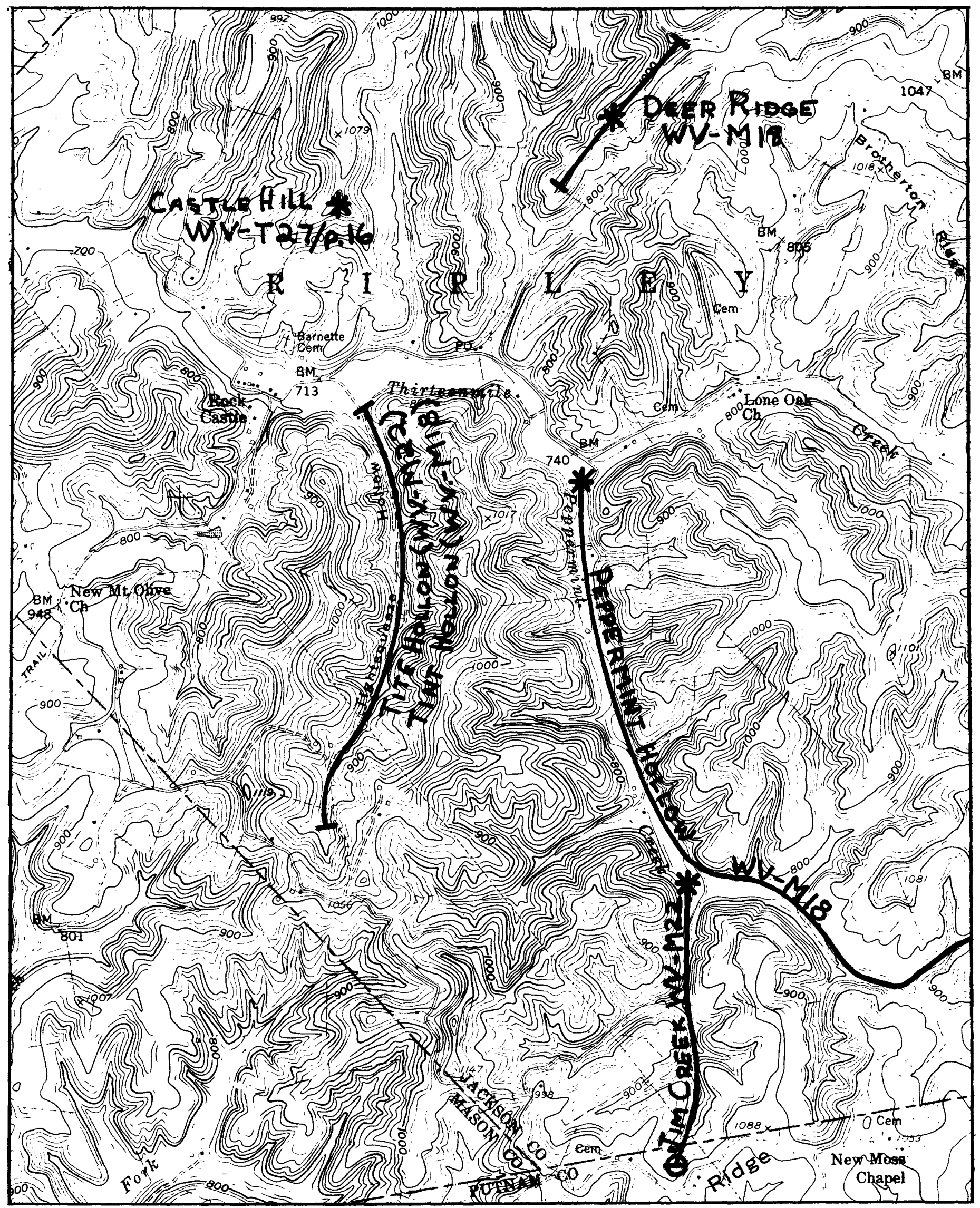

Figure 6.--An example of map-face annotations with bibliographic codes. The identification and extent of the referenced features are delineated directly on the face of the map. 


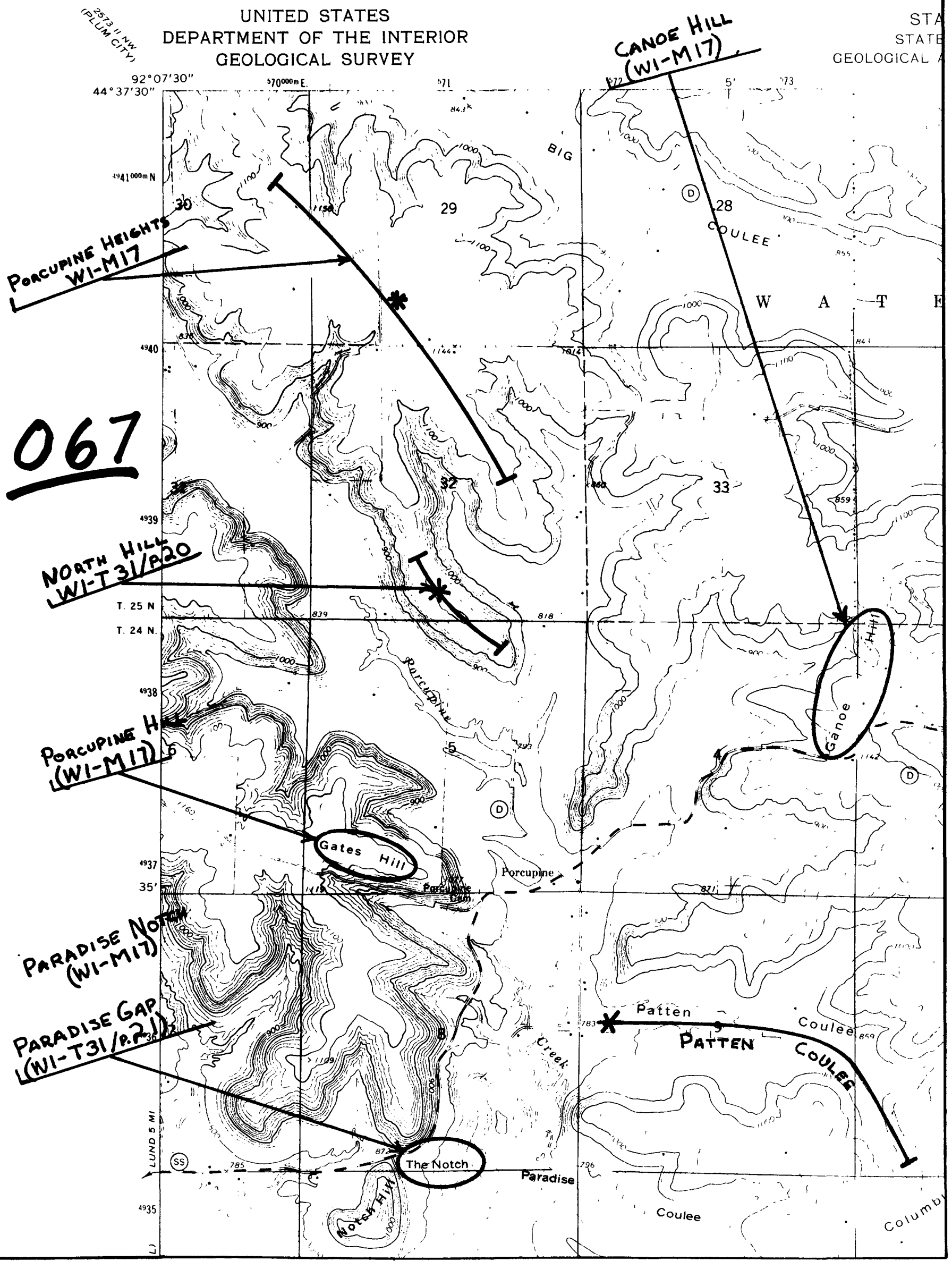

Figure 7.--An example of map-collar annotations with bibliographic codes. The "067" refers to the FIPS County code. Patton Coulee is a map-face annotation. 
Not all landscape and cultural features are symbolized on the topographic work maps. If an appropriate symbol is not shown on the work map, one should be annotated neatly in the proper location and identified by the normal name and bibliographic code annotation.

Annotation may be done by a fine-point felt-tipped pen, a good ballpoint or standard marking pen, or by a sharp, but not excessively hard, pencil. It is advisable to annotate new names in a specific color and variant names in a contrasting color. It is also possible to annotate name/feature application differences in another color. The method used should be documented and applied consistently.

Only one annotation is required to build a name record. If a new name or variant name, encountered during document research, is already annotated on the work map from a previous source, it can be ignored unless the later source contains additional useful information not found on the previous source. For example, it is useful to keep an account of the earliest usage of a name.

Name Categories Exempt from Annotation

As mentioned earlier, certain categories of named entities were not compiled during Phase $I$ because the information needed to build the name record was readily available in special listings or digital files. These listings are furnished to cooperators in the Phase II program by the GNIS Manager. Except for smaller dams and reservoirs, the following categories of named entities need not be extracted from the source documents and annotated on the work maps:

- Airports, landing strips, heliports;

- Dams and reservoirs; and

- Radio and television stations.

It should be noted that named streets, roads, and highways are not identified for inclusion in GNIS during Phases I or II.

\section{Topographic Map "Time-Gap" Procedures}

Phase I compilation was accomplished with a cut-off date for each state between 1976 and 1981. The compilation does not contain names published on the large-scale topographic maps after the cut-off date. A list of state cut-off dates will be furnished by the GNIS Manager. This procedure is temporary because new names from maps published within the "time-gap" will be compiled and added to GNIS at one time. Contact the GNIS Manager for the status of this compilation.

Because of the time gap between Phases I and II, the first step of Part 1 compilation is to identify additions or changes to the standard topographic map series published since the cut-off date on the work maps. The names are identified by the two-letter state FIPS code followed by a dash $(-)$ and the code M101. For example, OR-M101 identifies a new name or change on a topographic map of Oregon. This name data can be determined by comparing recently published maps with the largest-scale map coverage available for an area before the cut-off date. 


\section{County-Level and Minor Civil Division Names}

Phase I collection did not include county-level and minor civil division names because such nomenclature can be compiled best as a unit during Phase II work rather than on a map-by-map basis. The information is not annotated on the work maps, but instead recorded directly on Input Coding Forms (discussed on p. 22) and designated as "civil" on line "a3, DESIG" of the form. This compilation should include counties; civil parishes; towns (northeastern United States); named townships (land survey system); grants, patents, and hundreds; and any other named formal divisions of the land not recorded during Phase I compilation.

\section{Major Feature and Area Names}

Other categories of named entities sometimes not collected during Phase I operations include major natural features (such as Lake Michigan, Rocky Mountains, and Coast Range), extensive Federal and State parks and recreation and wildlife areas, and regional names. In all of these cases, no precise instructions can be given that will allow Phase II researchers to know if the records were, or were not, established during Phase I compilation. Researchers must check the computer printout or query the state file by means of a computer terminal in each case. Fortunately, the total number of these entities is not large.

Those major natural features and extensive parks, recreation, and wildlife areas to be added to the Phase II file can be plotted or outlined best on the 1:250,000-scale or state base maps furnished by the GNIS Manager. The data for building each name record can be developed from such map annotation ( $f i g .8$ ). The annotated intermediate-scale maps then become part of the work map collection for continual reference.

Currently used regional names are not normally found on topographic or on other base-map series. These names often can be found in the geographic literature. Regional names used in the past are found in the historical literature of a state or region. Because regional names often have indefinite boundaries, the Phase II researcher must interpret the area covered by a regional name so that an appropriate name record can be developed for the data base file. Precise boundaries are not nęeded.

\section{Variant Names}

All possible variant names and variant spellings should be annotated on the work maps along with their bibliographic codes for inclusion in the data base. This includes published typographical errors and minor spelling variations such as the inversion of "ie" and "ei" or " 11 " and " 1 ". All variant names, in each case, should be referenced to the named entity and not to the name. For example, a small settlement may be called Avon. If a post office or railroad station a mile away is also called Avon, there are two different named entities. James Creek and James Gorge, through which the stream flows, are two different features because the former is a hydrographic (water) feature and the latter is a hypsographic (land) feature. Ear'y maps and maps with scales too small for accurate name placement should be carefully interpreted in order to prevent the creation 


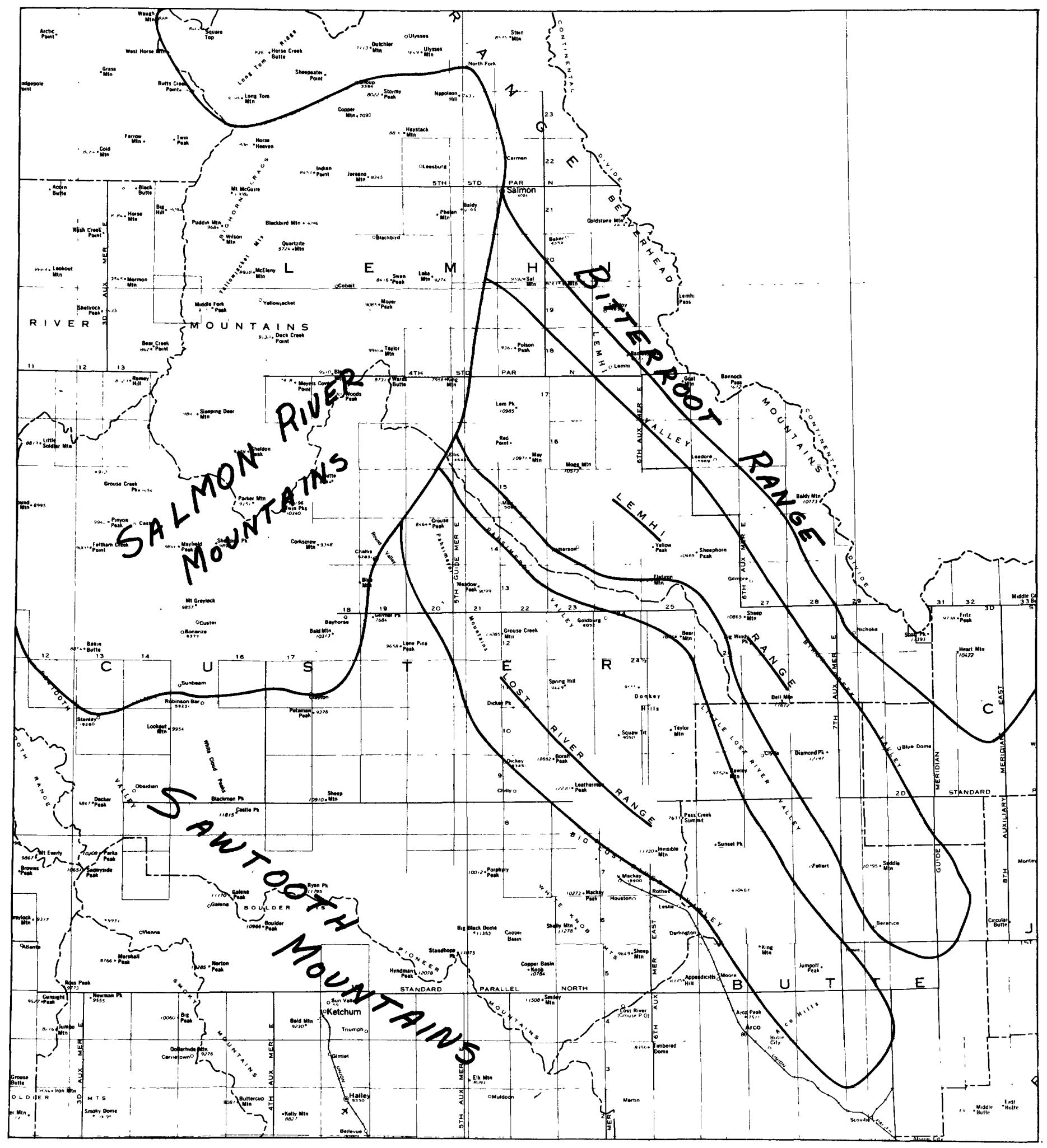

Figure 8.--It is best to delineate major named entities on $1: 250,000-$ scale or state base maps in order to understand their full extent and relationships with each other. Record data can be derived from the small-scale map or the feature boundaries can be transferred to the large-scale work maps. 
of variant names not intended by the mapmakers. Keep in mind the logical application of a name based on its generic element. A named cape applied to an island on a small-scale map was probably meant to apply to what was perceived as a cape and not the island. The relationship between a named mountain and its separately named peak or peaks should also be carefully maintained. Because of editorial policy or lack of space, names were sometimes abbreviated or the generic elements were left off the names. These should not be considered variant names. When recorded, the appropriate full name and generic should be given. See figure 9 for examples of name application differences on source documents which could result in the creation of variant names.

\title{
Controversial Names
}

A name controversy exists if the name of a populated place, locality, or natural feature or its application differs between any two of the following: (1) topographic map, the Phase I printout, (2) U.S. Forest Service map, or (3) National Ocean Service chart. If a controversy exists, the matter should be brought to the attention of the U.S. Board on Geographic Names. This can be done by submitting a Domestic Geographic Names Report (Form 9-1343), (fig. 10) as soon as possible to the:

\author{
Executive Secretary for Domestic Names \\ U.S. Board on Geographic Names \\ National Center 523 \\ Reston, Virginia 22092 \\ Te1. 703-860-6256; FTS 928-6256
}

The Board or its staff will resolve the controversy and notify the informant of the decision.

If the controversy exists for entities other than populated places, localities, and natural features, effort should be made to ascertain the name recognized by some form of administrative authority. When this name cannot be established, the researcher should choose the best one for the Record Name. All other names then become variant names.

Vague, Obsolete, and Vanished Entity Names

The National Geographic Names Data base is designed to be a total information depository of all obtainable names and associated information once or presently applied in writing to features, and areas of the United States and its territories. Every name, except those for streets, highways, and roads, should be recorded as a Record Name or variant name. This applies to the names of features that are no longer in use (landings, schools), the names of features that no longer exist (ghost towns, destroyed manmade and natural features), and historical and current names applied to vague entities (regions, areas). For example, sir Francis Drake applied the name "New Albion" to the land along the west coast of what is now the United States. New Albion is a legitimate name record for each of the states of California, Oregon, and possibly Washington, and should also be listed as a variant of these three name records. 
A. Source Map

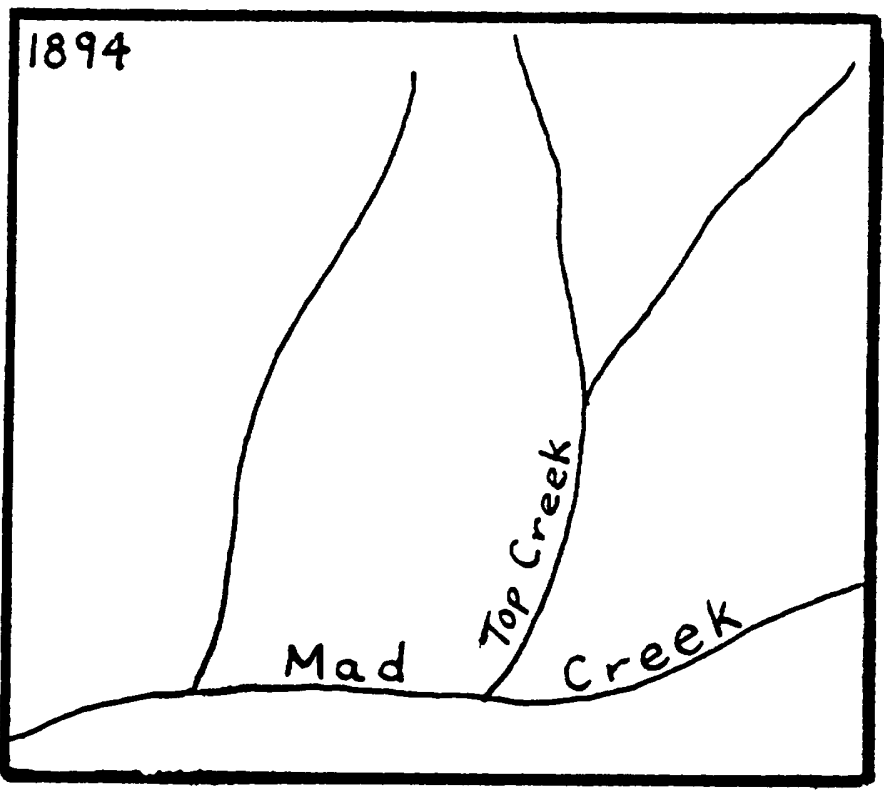

C. Source Map

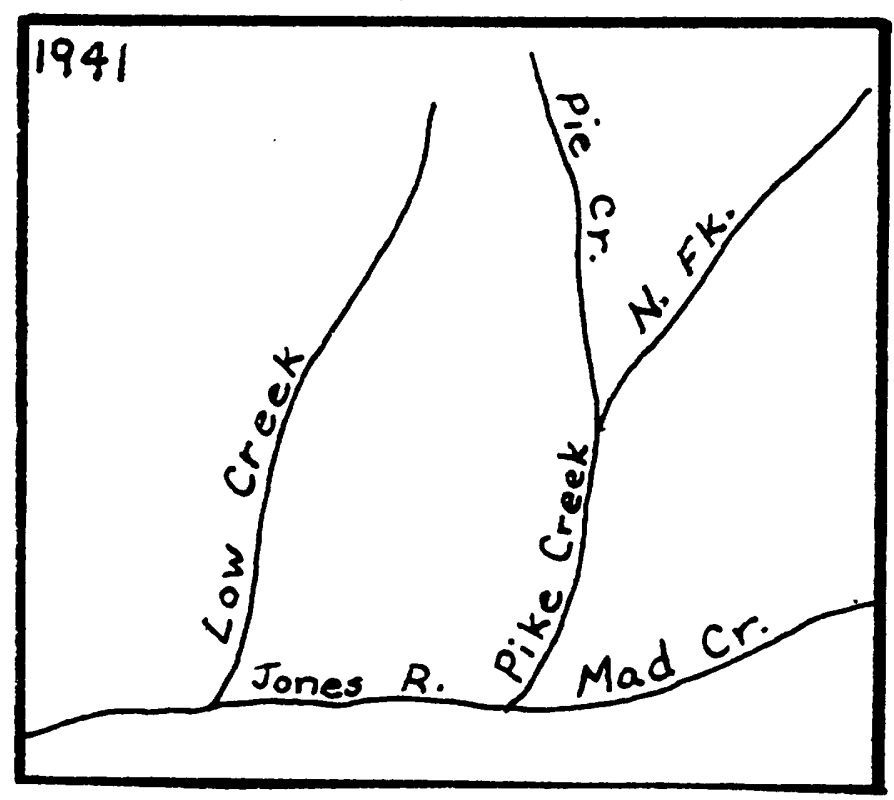

B. Source Map

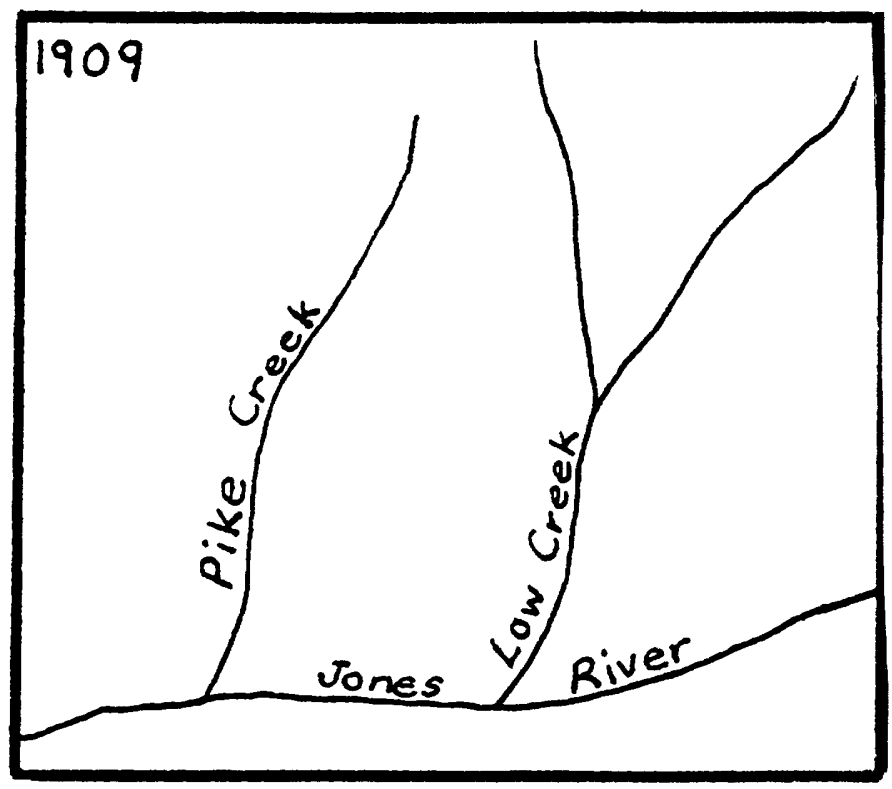

D. Work Map

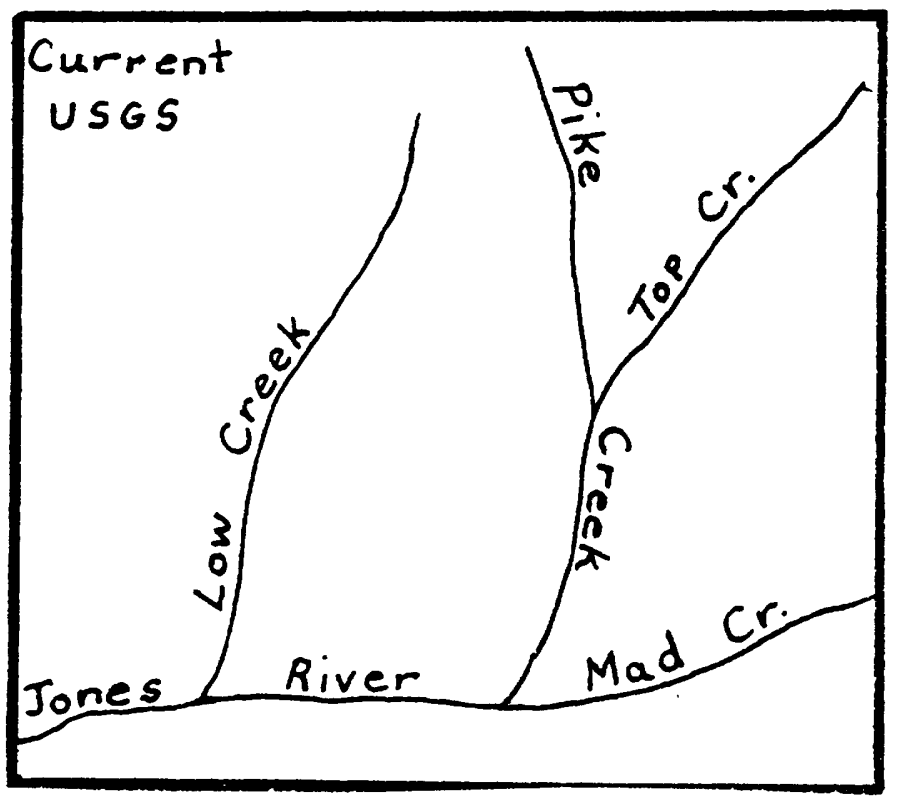

Figure 9.--Application Problems and Variant Names. When identifying variant names, each part of a feature or system of features uniquely named on a source map is considered a separate entity. A variant name is associated with a record name even though it may have been applied only to a part of the record name feature on a source document. The record name on map $D$ have the following variant names derived from source documents $A, B$, and $C$ :

Jones River - Mad Creek

Mad Creek - Jones River

Low Creek - Pike Creek

Pike Creek - Pie Creek, Low Creek, Top Creek

Top Creek - North Fork Pike Creek 
Form 9-1343 (Apr. 1967)

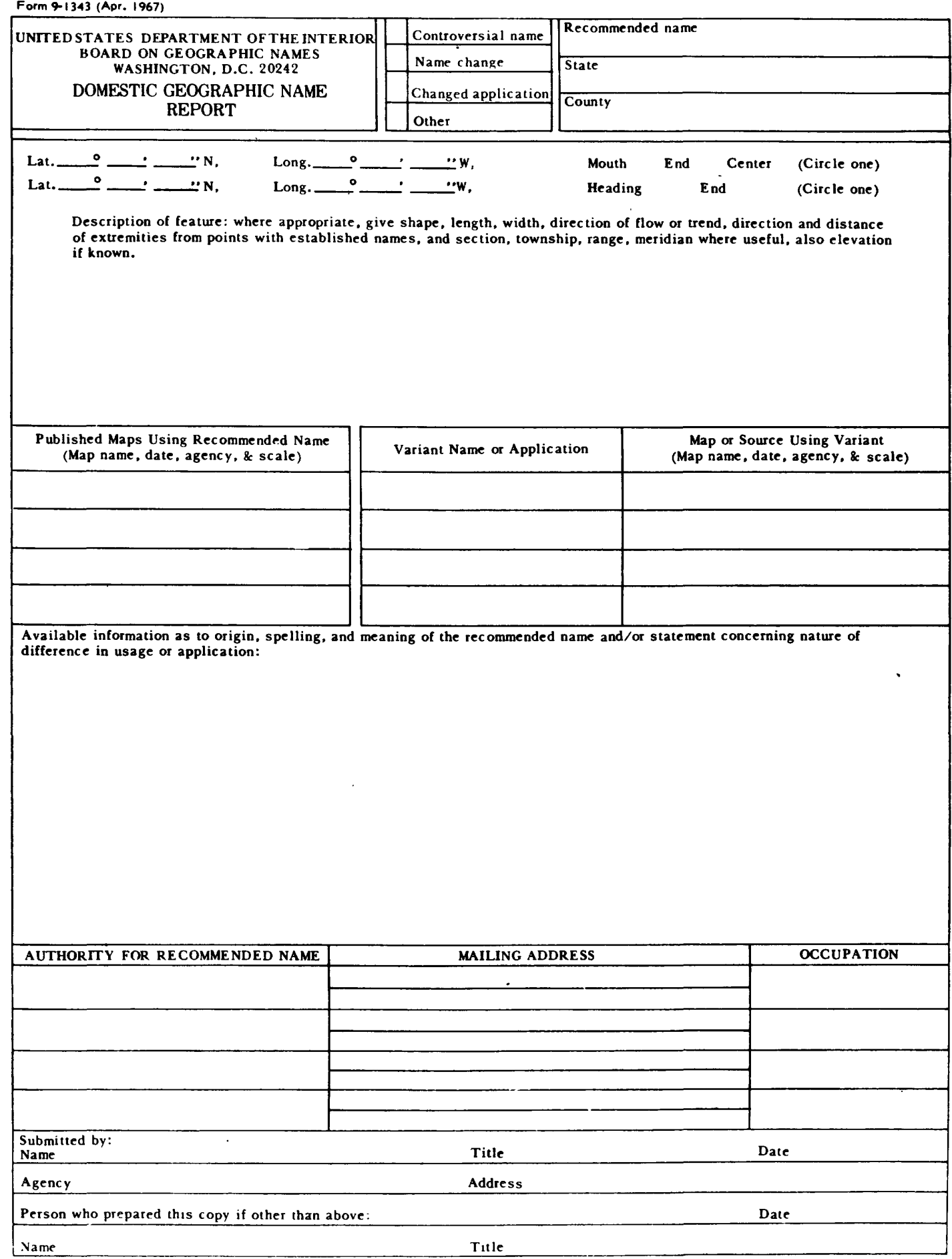

Figure 10.--An example of the Domestic Geographic Name Report used for submitting name problems to the U.S. Board on Geographic Names . 


\section{Information Sources}

The success of a Phase II compilation program depends upon the availability of source materials for research. Major university and city libraries with large historical and current map holdings and local history sections can furnish a large amount of source information for Phase II work. Research of State and local historical society publications and state, county, city, and town records is also important.

\section{Primary Federal Sources}

The primary Federal maps should be the first sources systematically reviewed after the preliminary work has been completed because official names are determined by usage on these maps. The names found on the topographic-map series published by the Geological survey are already in the system. For Phase II, the process involves comparing names and their applications shown on the National Ocean Service charts and the U.S. Forest Service maps with those shown on the work maps.

\section{Other Federal Sources}

After the primary Federal sources have been reviewed and processed, it is useful to systematically annotate the appropriate name information from the Federal listings made available by the GNIS Manager on the work maps. Most of the named entities in the listings will already be shown on the work maps and may only require quick visual verification. The listings, however, are more complete and, with the exception of the FIPS 55 list, represent official administrative names. The other Federal source listings include:

- U.S. Forest Recreation areas

- National Park Service: National

- Parks

- Historical parks

- Battlefields and battlefield sites

- Military parks

- Memorials

- Historic sites

- Monuments

- Preserves

- Seashores and lakeshores

- Parkways

- Rivers and riverways

- Recreation areas

- Scenic trails

- National Bureau of Standards, Federal Information Processing Standard FIPS 55 .

See figure 11 for an example of recommended methods for annotating Federal sources. 
State and Other Related Sources

Review and work map annotation of name data from the Federal documents should cover most major named places, features, and areas. Experience indicates, however, that this represents only about 50-70 percent of all names found in present-day usage. Thus, the next task of Phase II work is to identify the names of geographic entities in use today that are not already recorded. State and local governmental publications may be the best source of information of this kind. These documents include:

1. Maps produced by state agencies and local governments and

2. Special state and other governmental publications dealing with -

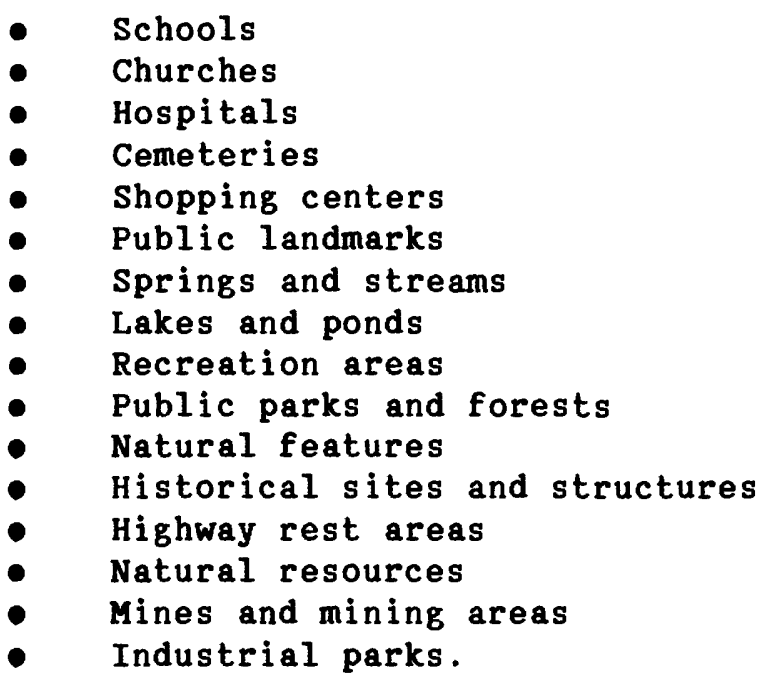

The names of subdivisions and real estate developments are useful records to have in the National Geographic Names Data Base, even though many of the names are ephemeral and may not be published in the National Gazetteer series. These names represent populated areas that are normally recognized by a legal process at some level of government. Most are not named on the topographic work maps. Information about the names and locations of real estate developments normally is available at the governmental office or agency that deals with zoning or planning and through real estate multiple listing maps.

Historical and Other Publications and Records

Almost all written material uses geographic names for locational purposes. Source documents for Phase II, Part I work are almost unlimited. Careful selection of sources that provide the greatest potential of new name information is important because of time limitations. After the required Federal and state source documents have been resgarched, the remaining kinds of information needed for the data base include:

- Historical and obsolete names,

- Indian and other minority group names,

- Regional and area names, and

- Minor feature names. 


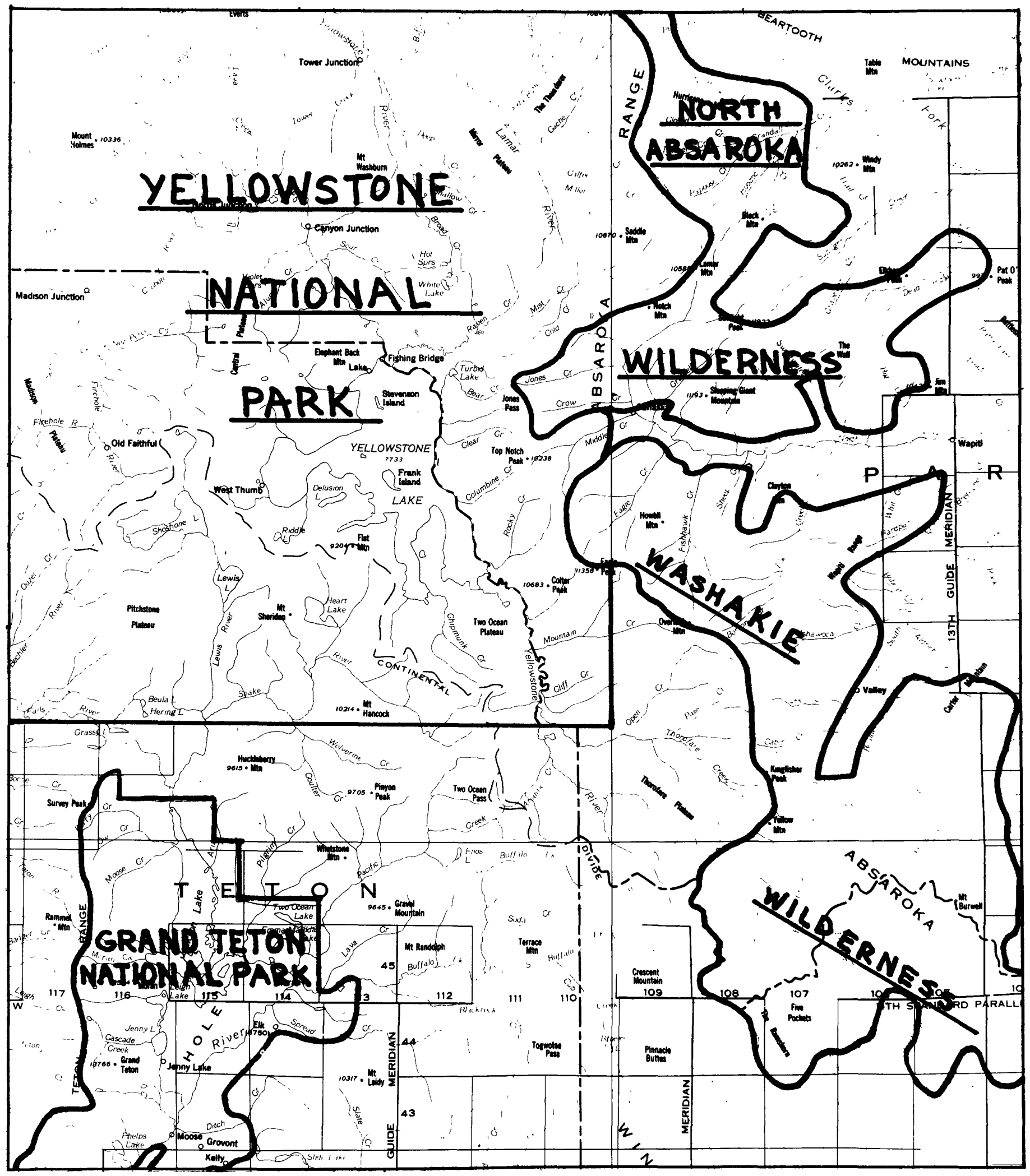

Figure 11.--Annotating named Federal and State entities. As with major features, it is best to identify scattered and large named areas that fall under the administrative authority of a Federal or state agency on a small-scale map. This procedure helps the compiler to understand extent and relationships not easily discernable on the larger scale work maps. County boundaries also can be annotated on the small-scale map if it is considered helpful. 
The availability of documents from which useful information can be obtained varies among states and among areas within a state. The more obvious possible source documents are:

- Historical maps and atlases;

- Books and pamphlets on local history;

- old Federal reports, maps, charts, and guides including census listings, coast pilots, postal guides, and reports on explorations;

- Land records and plats;

- State and regional geographic names studies and books;

- City plats, and county and regional maps;

- Etymological texts and materials; and

- Early written records dealing with travel, exploration, and settlement.

It is reiterated that priorities and limits need to be established to prevent an excessive amount of research time spent on going through sources that furnish minimal results.

\section{PHASE II, PART 2: ENCODING PREPARATION}

Part 1 involves the collection of name data on a master set of work maps. Parts 2 and 3 require the transfer and conversion of both the annotated and printed map data into machine-readable form for inclusion into the National Geographic Names Data Base. Although it is possible to encode name records directly from the work maps to the computer, such a procedure is not normally recommended because it requires special equipment and highly skilled operators, has a greater error factor, and is more difficult to monitor. Instead, an intermediate step, Part 2, is used. It involves the transfer of annotated and published map data to an Input Coding Form for each name record (fig. 12). The Input Coding Form is then used for digitizing the data for entry into the computer system.

\section{Data Transfer}

All data must be carefully and clearly printed on the Input Coding Form in upper and lower case (or as directed) and in exactly the same form as shown on the work maps, except that all abbreviations must be spelled out.

\section{Data Elements and Record Format}

Each name record consists of categories of information called data elements. The data elements are listed on the Input Coding Form in the order in which they will be encoded for machine entry. Any specific entity can have only one record name in the data base. Each data element is identified by $a$ :

- Descriptive name (Record Name),

- Label (Name), and

- Format code. 
Geographic Names Information System (GNIS) Data Element Entries For Phase II Compilation

Input Coding Form

(a1) NAME

(a3) DESIG

(a4) * LOC

(a5) $* *$ COUNTY

(a6) *LATLONG

(a7) HEADS

(a8) *MAP

(a9) **MAP NAME

(a11) ELEV

(a16) *VAR

(a17) SIZE

(a18) STATUS

(a19) SPDESIG

(a20) STR

(a99) BIBLIO

*multiple entries required if necessary - if corrections are required with multiple entries, then all entries must be re-entered

**one entry only--location of the primary coordinate

Figure 12.--Input Coding Form. 


\section{Record Name}

The geographic name entered on line al of the Input Coding Form is the official or primary name to which all variant names and spellings are referenced. Normal spacing and upper-lower case spelling are to be used regardless of the type placement on the source document (example:

"Lakewood" not "LAKEWOOD.") Exceptions occur when an upper-case letter is normally used within the body of the specific part of a name; DeKalb, LaMarr.

Except for the genitive (possessive) apostrophe, all non-letter characters that are part of the name are to be properly recorded on the coding form. This includes the apostrophe ( $0^{\prime}$ Malley Creek), hyphen (Miller-White Ditch), acute $(/)$, grave $(\backslash)$, circumflex $(\Lambda)$, tilde $(\sim)$, and cedilla (c).

Each name is printed letter by letter, word by word, in its normal order except in those cases where the generic part of the name of a natural (physical) feature precedes the specific part as in Mount Adams, Lake Ann, Bay Saint Louis, and Lake of the Woods. In such cases the specific or substantive part is listied first, followed by a comma, a blank space, and the remaining parts of the names:

Adams, Mount

Ann, Lake

Saint Louis, Bay

Woods, Lake of the.

However, a populated place, locality, or civil division (city, village, county, township, crossroad, and railroad siding) named for a physical feature is always listed in normal order even though the generic part of the name may precede the specific part. A village or locality called "Mount Calvary" is listed in that order, while a physical feature with the same name is shown with the specific part of the name first; that is, "Calvary, Mount."

\section{Feature Class}

The feature classes (line a3) are designed to group similar features into broad categories to facilitate search and retrieval. The Map Feature Guide (Appendix G) provides a reference for all known geographic-name generics to the appropriate broad feature class. However, if a geographicname generic not yet in GNIS is encountered, it should be recorded on the "Generic Information" form (fig. 13).

\section{State/County Codes}

"The Standard for Counties and County Equivalents of the states of the United States" (FIPS PUB 6-2, latest edition) published by the U.S. National Bureau of standards will be the source for codes on line a4 to identify the states and Counties in which a named feature occurs. The individual code is five digits. The first two digits refer to the state and the last three digits refer to the county or county equivalent. This 
is a numeric variable-length field. A five-digit state/County code will be recorded for each county and state in which the named entity is located. When more than one code is entered, the state and county in which the primary coordinate symbol is located is listed first. The sequence thereafter is from mouth to source for drainage features, referred to in GNIS as linear features.

When a feature is in both the United States and another country, the appropriate 2-character alphabetical FIPS code will be used, for example, CA for Canada, MX for Mexico, UR for Soviet Union, UK for the United Kingdom, and WS for Western Samoa.

\section{County Name}

The specific part of the county name, or county equivalent name, is printed on line a5. Only the county name where the primary coordinate, is located is recorded. No multiple entries or data items are permitted for this data element. Only the specific part of the name is listed. Arlington County and Terrebonne Parish are listed as:

$$
\begin{aligned}
& \text { Arlington } \\
& \text { Terrebonne. }
\end{aligned}
$$

If the primary coordinate is located in an independent city the specific name of the city or town followed by the word city in parentheses.

Richmond (city).

\section{Geographic Coordinates}

A 15-character compressed geographic coordinate is used in 1 ine a6 for primary and secondary points. Multiple data items are separated by a blank space. If the degrees of longitude are less than 100 a leading 0 must be present. Example: 250607N0713214W.

The primary and secondary coordinates are geographic coordinates that not only locate and indicate certain feature limits, but also associate a named feature with the map or maps on which it appears. Latitude is in degrees, minutes, and seconds followed by one alphabetical directional character ( $N$ or $S$ ); and longitude is in degrees, minutes, and seconds followed by one alphabetical directional character ( $E$ or $W$ ). There is a geographic coordinate associated with each topographic map or cell on which a feature is located. The primary coordinate followed by all secondary coordinates will be recorded after the precedence code "a6." Multiple entries or data items may be reguired. The order recorded is from mouth to source for linear features and generally from the center outward for areal features.

All primary and secondary coordinates must be recorded within \pm 5 seconds (about 400 feet) of accuracy at a scale of $1: 24,000$ or $1: 25,000$. Geographic coordinates may be accurately determined by means of 10-space dividers, scaling rulers, special coordinate overlays, or by the use of an electronic digitizer. Procedures for establishing coordinates for Phase II encoding should be arranged between the cooperator and the GNIS Manager. 
Generic or Unusual Word

GNIS Feature Class

Location of the Geographic Coordinate

Is a Source Coordinate necessary?

Standard Abbreviation (if known)

MAPNAME

SCALE

STATE

GNIS MAP NUMBER

Description and type of Feature to which THE GENERIC REFERS

OTHER PERTINENT INFORMATION

Figure 13.--Generic information form used to identify and report new generic words found in geographic names. 
The Primary Coordinate entry is the first coordinate on the form and should locate a point at the mouth of a linear feature and at the approximate center of an areal feature. Specific instructions as to where the geographic coordinates are to be taken are found in the Map Feature Guide (Appendix G) or may be obtained interactively by accessing the Generic Data Base. The approximate center must be determined subjectively for areal features with indefinite, irregular, or non-discernable boundaries. The centers of populated places often may be determined by locating certain features such as the town or city hall, main library, main post office, the old central business district, or a main intersection. The mouth of a natural feature refers to the terminus of linear entities such as streams, valleys, and canyons and is located where the feature joins another feature of the same kind, ends in a delta, an alluvial fan, or no longer has a discernable channel or troughlike characteristics. Primary coordinates for entities classified as summits are recorded at the tops or highest points of the features. The Primary Coordinate entry corresponds to the data elements County Name and Map Name and corresponds to the first entry in State/County Code and GNIS Map Number.

The appropriate Primary Coordinate should be recorded if it is available. If the Primary Coordinate is not available, enter the 15-character entry *PRIMARY COORD* followed by all subsequent secondary Coordinates related to the named feature.

The Secondary Coordinate is a point arbitrarily chosen to locate the named feature on maps or cells through which it passes or on maps that do not contain the Primary Coordinate. Choose only one Secondary Coordinate for each $7.5 \times 7.5$-minute cell on which the feature is located. Its only purpose is to identify the name with the map and general extent of the feature. The location of each Secondary Coordinate may be anywhere on the map as long as it is located on the feature in question. All secondary Coordinates correspond on a one-to-one basis with multiple data items in the GNIS Map Number data element.

\section{Source Coordinate}

The Source Coordinate is a 15-character compressed geographic coordinate identical in format to the coordinates found in the Primary and Secondary Coordinate field. There must be only one geographic coordinate to represent the source of a linear feature on line a7.

The annotator will assign the Source Coordinate symbol 0 to the furthest point at the head of the longest, straightest extension of the named feature unless its location is otherwise defined on the map by name placement, textual description, or other influencing variable. This procedure is in accordance with the policies of the U.S. Board on Geographic Names. See figure 14 for examples of locating points for Source Coordi-

nates. If the Source Coordinate is outside the state, the appropriate coordinate should be obtained. If it is not available, the line on the coding form will be filled in with *SOURCE COORD*.

\section{GNIS Map Number}

The GNIS Map Number on 1 ine $a 8$ is a four-digit numerical code that refers to each $7.5 \times 7.5$ minute cell. Multiple data items may be required and are separated by a blank space. The GNIS Map Number corresponds to 
each of the primary and secondary geographic coordinates on a one-to-one basis and the last GNIS Map Number recorded refers to the map showing the source coordinates of certain linear features. An exception to the above rule occurs when either the mouth or source of a linear feature lies outside the state or some portion of an areal feature is outside the state. In this case no corresponding map number can be recorded.

The four-digit numbering system begins in the northwest corner of each state or territory and the numbers increase consecutively from west to east while moving latitudinally southward. Each state is numbered in the same way. Thus, the same map may have two or more different numbers when parts of two or more states are covered by the same map. For this reason, map numbers for parts of features outside the state being worked are not recorded.

Because the GNIS Map Number must always be a four-digit number, it is necessary to add leading zeros. to numbers less than 1000; example: 0010 and 0279. Map numbers correspond on a one-to-one basis with geographic coordinates unless the primary or source coordinate is outside the state.

\section{Map/Chart Name}

Line a9 on the coding Form allows for the inclusion of a variablelength map name. The entry for this field is the name of the topographic map which contains the location of the Primary Coordinate of the feature, even though the feature may not be named and (or) not symbolized on the map. If a feature lies outside the bounds of topographic map coverage, reference to a chart source should be made if applicable. For example, the reference NOS 12345 indicates that the feature is covered on National Ocean Service Chart 12345 and is outside the bounds of the National Topographic Map Series. Record only one entry for each feature. If the Primary Coordinate of a feature lies outside the boundaries of the state being encoded, record the name of the map followed by a blank space and the two-character alphabetical FIPS code for the state in which the Primary Coordinate is located.

\section{Elevation}

Topographic maps show elevations for selected points, such as the summits of hills and mountains, crossroads, mountain passes or gaps, lakes and ponds, and dams. Surveyed points are shown in black print, photogrammetrically determined elevations are in brown, and water elevations are shown in blue. Every effort should be made to record the elevations of named features on line a eleven when appropriate. Elevations are not recorded for streams, but it will be useful to have elevations for most named bodies of water, such as ponds, lakes, and reservoirs, and for passes and gaps. Elevations are required for all populated places, locales, and summits. Elevations not recorded on the map can be determined by interpolating contours.

The following rules apply to determining and recording elevations:

- Only one elevation will be recorded for each name record;

- Elevations are to be given in feet; 


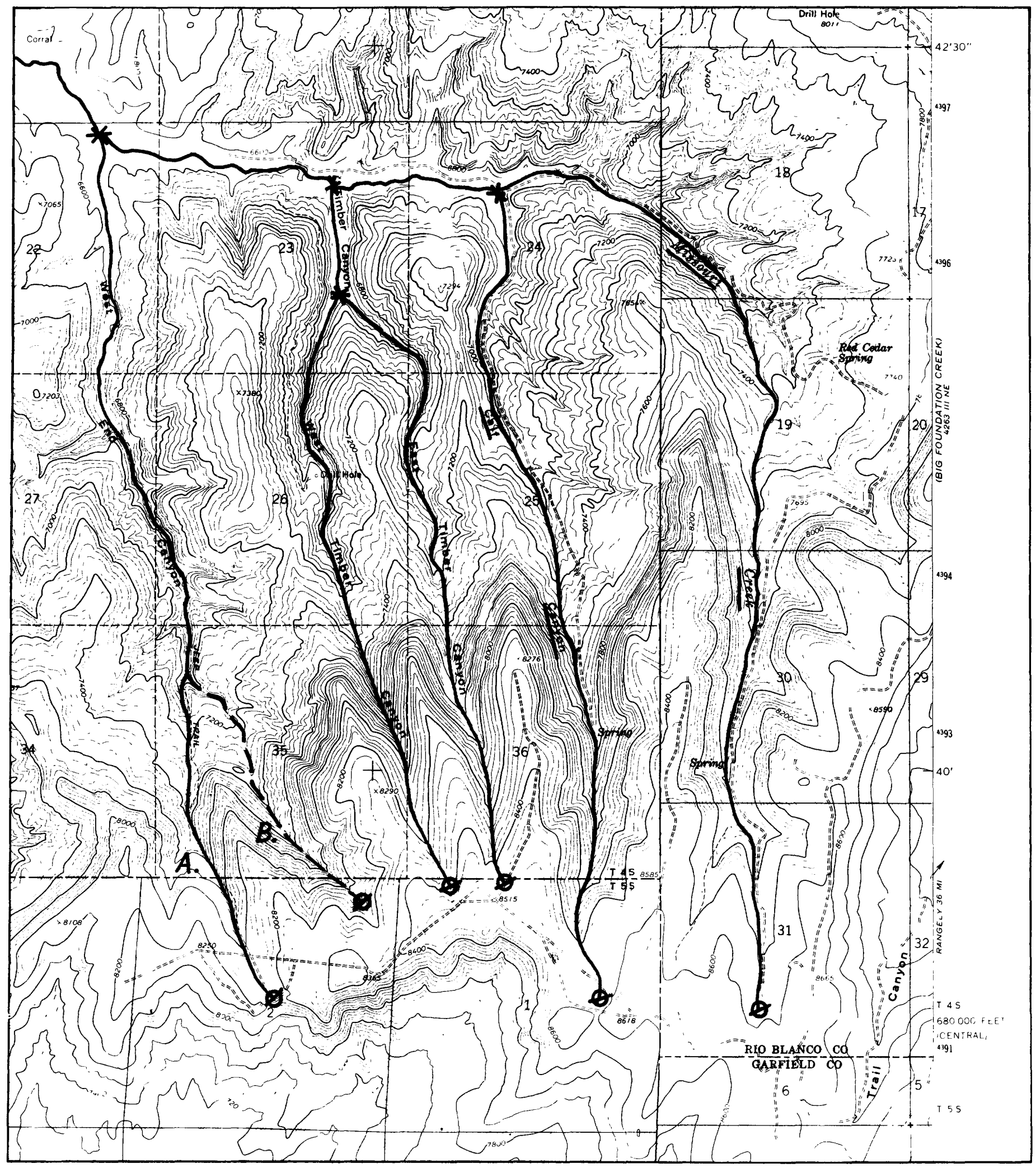

Figure 14.--A head coordinate is to be taken at the extreme head of the longest, straightest branch of a stream and the longest, straightest, or deepest branch of a canyon. The head coordinate is established at the extreme head of drainage determined by reentrant contour lines and not necessarily at the end of a stream symbol or end of the name printed on the map. In figure 1 , West End Canyon represents a borderline case. However, it appears that its head coordinate would be best established on branch $A$ because it is the longest and straightest branch. 
- Elevations may be no longer than five characters including a negative symbol;

- Elevations are to be recorded at, or very near, the Primary Coordinate;

- Negative values (feet below sea level) are preceded with a minus sign $(-)$;

- Elevations are determined for the highest points of summits such as mountains, peaks, hills, mesas, ridges, mounds, and bluffs;

- Elevations are determined for the lowest points of passes, gaps, notches, and basins;

- Elevations for bodies of water, such as lakes, ponds, and reservoirs are determined by water level.

- Elevations for the GNIS categories of populated place (ppl), locale, and summit, when not published on the map, should be estimated according to the location of the Primary coordinate between the upper and lower contour lines.

\section{Variant Name(s)}

Variant Name, recorded on 1 ine a16, refers to all other known names or spellings once or presently applied to the entity identified by the Record Name. This is an important category of information and reasonable effort should be made to obtain as many variant names and variant spellings of a name as possible. This is done by investigating name use on historical maps, atlases, and gazetteers. The following rules apply to the recording of Variant Names on the coding form:

- If more than one Variant Name exists for a record, they are arranged alphabetically and separated by a comma and a blank space.

- The bibliographic code must be recorded with entries discovered in sources other than USGS topographic maps. The code is in parentheses and follows the variant.

- If the U.S. Board on Geographic Names has rendered a former decision on a Variant Name, the characters BGN followed by a blank and the year of the decision are recorded in parentheses after the variant. This information usually already will have been added during Phase I compilation.

\section{Size of Feature}

The size of the feature refers to a short variable length, upper/lower case, alphanumeric description that indicates the length of linear features and the breadth of areal features in English units. After the precedence code a17, it is possible to enter a short phrase indicating size. Example: 41 miles long and 2 miles wide, 123 miles long, 8 acres.

\section{Federal Status}

This code indicates the status of the Record Name and its application as determined by U.S. Board on Geographic Names. See Appendix D for a 1 ist of feature classes associated with status categories. After the precedence code al8, enter an all-upper-case entry for status. The possible categories are: 


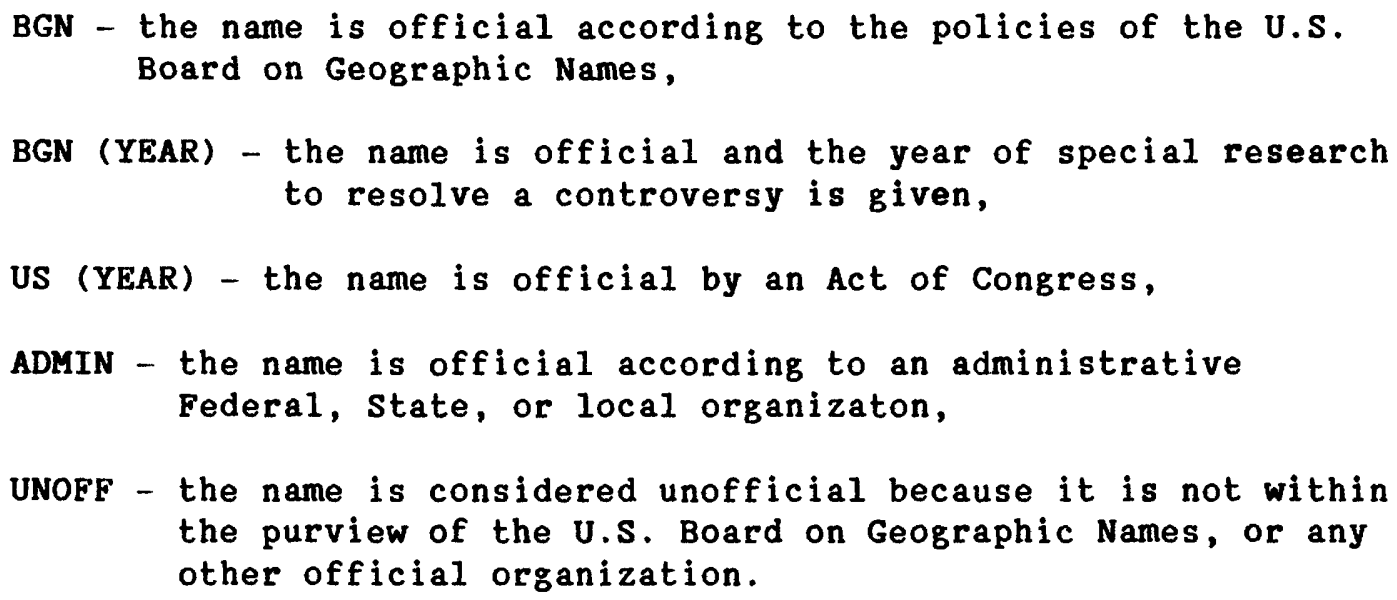

Special Designators

Special designators on 1 ine a19 currently indicated the ownership of administrative areas. Entries should be made according to the following categories :

Federally owned,

State owned,

Municipally owned, and

Privately owned

Section, Township, Range, and Meridian

The section, township, range, and meridian information should be recorded on 1 ine 220 in the following manner.

Example: $220 \sec 10, \mathrm{~T} 14 \mathrm{~N}, \mathrm{R} 20 \mathrm{~W}, \mathrm{Gila}$ and Salt River Meridian

If all information is not available, as sometimes is the case with section numbers, the available information will be recorded accordingly.

\section{Bibliographic Entry}

The Bibliographic Entry on 1 ine a99 provides a ready reference to the exact compilation source of all names not recorded from USGS topographic maps. The absence of the code indicates that the name was recorded on the USGS topographic map during Phase I compilation (1976-1981). See pages 13 through 14 for a description of the code. If no bibliographic code is available, enter the word none. The line should not be left blank because an entry is needed to close the record. The complete annotated bibliography used in Phase II compilation for each State will be available in the Generic Data Base. 


\section{PHASE II, PART 3: ENCODING DATA}

Once Phase II name data have been collected and annotated on the work maps, and after the coding forms have been filled out, the name records are ready to be put into machine-readable form and become part of the National Geographic Names Data Base. Part 3 involves the actual encoding of data for entry into the system. Technical information on the equipment and procedures necessary for this operation is obtainable from the GNIS Manager. Additional comments regarding current encoding procedures for the record data elements are 1 isted below. Changes and enhancements to the procedures may be made periodically and the GNIS Manager should be consulted before any actual keying of data is done.

- Record Name - al: If the computer system being used does not provide for the recording of diacritical marks, the name should be followed by a blank space followed by an asterisk to indicate the presence of a special writing mark in the name, for example, Canon del Norte $*$.

- Feature Class - 23: The feature-class term is recorded and entered in lower-case letters only.

- State/County Codes - a4: If a correction is required in cases having more than one state/county entry, all entries must be retyped. Multiple entries must be separated by a blank space.

- Geographic Coordinates - a6: Multiple sets of coordinates are separated by a blank space. If any part of a multiple entry is corrected, all entries must be rekeyed. The geographical coordinates, latitude and longitude, are compressed into 15-characters with a blank space between multiple entries.

- GNIS MAP Number - a8: Multiple map numbers in an entry require rekeying if a correction is made. The numerical entry must be four digits.

- Elevation - a11: All numerical elevations are to be justified on the left and are not to exceed five character spaces. 


\section{APPENDIX A:-GEOGRAPHIC NAMES INFORMATION SYSTEM CATEGORIES OF NAMED FEATURES NOT YET INCLUDED}

\section{Phase I}

Generally, all named features on the most-current largest-scale USGS topographic maps were included for Phase I compilation. Some categories of named features, however, were omitted from Phase I because more complete 1 ists of these categories were available from other sources. If a State or territory has been completed only through Phase $I$, the following categories of named features will not be present:

- Airports,

- Radio and television station towers,

- Federally administered areas greater than 30 square miles,

- Major and minor civil divisions,

- Some major or large features that are too large to be named on 7.5-minute, 1:24,000-scale topographic maps,

- Regional names,

- Historical names,

- Most building names,

- Roads and highways, and

- Triangulation station names.

Phase II

Available information from the categories not compiled during Phase I, as well as geographic names from other sources, are added during Phase II. If a state or territory has been completed through Phase II compilation, information for all known named features should be present except for roads and highways and triangulation stations. 


\section{APPENDIX B:-GEOGRAPHIC NAMES INFORMATION SYSTEM CHECKLIST OF SOURCES}

Required sources in order of their research and compilation

- USGS quadrangle maps published or reprinted since Phase I compilation

- National Ocean Service (NOS) Charts and River and Lake Charts

- U.S. Forest Service Maps

- U.S.Board on Geographic Names list of names not found on USGS maps

- U.S. National Bureau of Standards FIPS 55 list

- U.S. Army Corps of Engineers Dams and Reservoirs 1ist

- Federal Aviation Administration Airport list

- National Park Service lists

- U.S. Forest Service Recreation area 1 ist

- Federal Communication Commission Radio and television station list

- Shopping Center listing

- County maps published by the state (not provided by USGS)

- Other state maps (highway, etc.) (not provided by USGS)

- Real estate multiple listing maps (not provided by USGS)

- List of schools, and churches (not provided by USGS)

- Historical maps, atlases, and gazetteers

Additional information is to be added for:

- Counties

- Townships

- other minor civil divisions

- State and Federal Recreation, wildlife areas, etc.

- Missing major or large features

- Regional names

Optional Sources are:

- City plats

- Textual material having reference to geographic names

- Historical Federal sources such as old NOS charts and pilots, old Postal Guides, etc.

- Bureau of Indian Affairs information 
APPENDIX C:-GEOGRAPHIC NAMES INFORMATION SYSTEM USGS TOPOGRAPHIC MAP PREPARATION AND INSTRUCTIONS

- Outline county boundaries

- Annotate FIPS codes on map collar adjacent to the county

- Draw lines at 2.5-minute ticks for determining coordinates if coordinates are determined manually

- Annotate GNIS map number on lower left collar (include leading zeros

- Editing checks

- Add new variants

- Prepare annotated Bibliography

- Interpolate elevations for populated places (ppl), locales and summits 
APPENDIX D:-GEOGRAPHIC NAMES INFORMATION SYSTEM STATUS CATEGORY CLASSIFICATION

\begin{tabular}{|c|c|c|c|c|c|}
\hline ADMIN & - & $\begin{array}{l}\text { airport } \\
\text { civil }\end{array}$ & $\begin{array}{l}\text { forest } \\
\text { park }\end{array}$ & & \\
\hline UNOFF & - & $\begin{array}{l}\text { bridge } \\
\text { building } \\
\text { cemetery } \\
\text { church } \\
\text { dam } \\
\text { hospital } \\
\text { mine }\end{array}$ & $\begin{array}{l}\text { oilfield } \\
\text { other } \\
\text { school } \\
\text { tower } \\
\text { trail } \\
\text { tunnel } \\
\text { well }\end{array}$ & & \\
\hline BGN & - & $\begin{array}{l}\text { arch } \\
\text { area } \\
\text { arroyo } \\
\text { bar } \\
\text { basin } \\
\text { bay } \\
\text { beach } \\
\text { bench } \\
\text { bend } \\
\text { canal } \\
\text { cape }\end{array}$ & $\begin{array}{l}\text { cave } \\
\text { channel } \\
\text { cliff } \\
\text { crater } \\
\text { falls } \\
\text { flat } \\
\text { gap } \\
\text { geyser } \\
\text { glacier } \\
\text { gut } \\
\text { harbor }\end{array}$ & $\begin{array}{l}\text { island } \\
\text { isthmus } \\
\text { lake } \\
\text { lava } \\
\text { levee } \\
\text { locale } \\
\text { pillar } \\
\text { plain } \\
\text { ppl } \\
\text { range } \\
\text { rapids }\end{array}$ & $\begin{array}{l}\text { reserve } \\
\text { reservoir } \\
\text { ridge } \\
\text { sea } \\
\text { slope } \\
\text { spring } \\
\text { stream } \\
\text { summit } \\
\text { swamp } \\
\text { valley } \\
\text { woods }\end{array}$ \\
\hline
\end{tabular}




\section{APPENDIX E:-GEOGRAPHIC NAMES INFORMATION SYSTEM FEATURE-CLASS TERMS}

The feature-class terms and abbreviations currently consist of up to nine letters. They were chosen for computer search and retrieval purposes and do not necessarily represent terminology for the identification of all kinds of cultural and natural features. Although some of the terms may agree with dictionary definitions, they represent more generalized categories. Some commonly used generic names are 1 isted at the end of each entry to assist in understanding the range of cultural and natural entities represented by the term. Refer to the Generic Data Base to retrieve all generics thus far encountered in geographic names compilation. In most instances a plural form is listed as if it were singular; for example, archipelago or islands would be categorized as island. The terms and the definitions are as follows:

airport -- manmade facility maintained for the use of aircraft (air-field, airstrip, landing field, landing strip).

arch -- natural arch-like opening in a rock mass (bridge, natural

bridge, sea arch).

area -- any one of several areally extensive natural features not

included in other categories (badlands, barren, delta', fan, garden).

arroyo -- watercourse or channel through which water may occasionally

flow (coulee, draw, gully, wash).

bar -- natural accumulation of sand, gravel, or alluvium forming an

underwater or exposed embankment (ledge, reef, sandbar, shoal, spit).

basin -- natural depression or relatively low area enclosed by higher

land (amphitheater, cirque, pit, sink).

bay -- indentation of a coastline or shoreline enclosing a part of a body of water; a body of water partly surrounded by land (arm, bight, cove, estuary, gulf, inlet, sound).

beach -- the sloping shore along a body of water that is washed by waves or tides and is usually covered by sand or gravel (coast, shore, strand).

bench -- area of relatively level land on the flank of an elevation such as a hill, ridge, or mountain where the slope of the land rises on one side and descends on the opposite side (level).

bend -- curve in the course of a stream and (or) the land within the

curve; a curve in a linear body of water (bottom, 100p, meander).

bridge -- manmade structure carrying a trail, road, or other transpor-

tation system across a body of water or depression (causeway, overpass, trestle).

building -- a manmade structure with walls and a roof for protection of people and (or) materials but not including a church, hospital, or school.

canal -- manmade waterway used by watercraft or for drainage, irriga-

tion, mining, or water power (ditch, lateral).

cape -- projection of land extending into a body of water (lea, neck, peninsula, point):

cave -- natural underground passageway or chamber, or a hollowed out

cavity in the side of a cliff (cavern, grotto).

cemetery - a place or area for burying the dead (burial, burying

ground, grave, memorial garden). 
channel -- linear deep part of a body of water through which the main volume of water flows and is frequently used as a route for watercraft:

(passage, reach, strait, thoroughfare, throughfare).

church -- building used for religious worship (chapel, mosque,

synagogue, tabernacle, temple).

civil -- a political division formed for administrative purposes

(borough, county, municipio, parish, town, township).

cliff -- very steep or vertical slope (bluff, crag, head, headland, nose, palisades, precipice, promontory, rim, rimrock).

crater -- circular depression at the summit of a volcanic cone or one

on the surface of the land caused by the impact of a meteorite; a manmade depression caused by an explosion (caldera, lua).

dam -- water barrier or embankment built across the course of a stream or into a body of water to control and (or) impound the flow of water

(breakwater, dike, jetty).

falls -- perpendicular or very steep fall of water in the course of a stream (cascade, cataract, waterfall).

flat - relative level area within a region of greater relief

(clearing, glade, playa).

forest -- bounded area of woods, forest, or grassland under the

administration of a political agency. (see woods) (national forest,

national grasslands, state forest).

gap - - low point or opening between hills or mountains or in a ridge

or mountain range ( $c 01$, notch, pass, saddle, water gap, wind gap).

geyser -- eruptive spring from which hot water and (or) steam and in

some cases mud are periodically thrown.

glacier -- body or stream of ice moving outward and downslope from an area of accumulation; an area of relatively permanent snow or ice on the top or side of a mountain or mountainous area (icefield, ice patch, snow patch).

gut - relatively small coastal waterway connecting larger bodies of water or other waterways (creek, inlet, slough).

harbor - sheltered area of water where ships or other watercraft can anchor or dock (hono, port, roads, roadstead).

hospital -- building where the sick or injured may receive medical or surgical attention (infirmary).

island -- area of dry or relatively dry land surrounded by water or

low wetland (archipelago, atoll, cay, hammock, hummock, isla, isle, key,

moku, rock).

isthmus -- narrow section of 1 and in a body of water connecting two

larger land areas.

lake -- natural body of inland water (backwater, lac, lagoon, laguna,

pond, poo1, resaca, waterhole).

lava - - formations resulting from the consolidation of molten rock on

the surface of the Earth (kepula, lava flow).

levee -- natural or manmade embankment flanking a stream (bank, berm).

locale -- place at which there is or was human activity; it does not

include populated places (pp1), mines, and dams (battlefield, crossroad,

camp, farm, ghost town, junction, landing, railroad siding, ranch, ruins, site, station, windmil1).

mine -- place or area from which commercial minerals are or were

removed from the Earth; not including oilfield (pit, quarry, shaft).

oilfield -- area where petroleum is or was removed from the Earth. 
other -- category for miscellaneously named manmade entities that cannot readily be placed in the other feature classes listed here.

park -- place or area set aside for recreation or preservation of a cultural or natural resource and under some form of government administration; not including National or State forests (national historical landmark, national park, state park, wilderness area). pillar -- vertical, standing, of ten spire-shaped, natural rock forma-tion (chimney, monument, pinnacle, pohaku, rock tower).

plain -- a region of general uniform slope, comparatively level and of considerable extent (grassland, highland, kula, plateau, upland). ppl -- populated place; place or area with clustered or scattered buildings and a permanent human population (city, settlement, town, village). range -- chain of hills or mountains; a somewhat linear complex mountainous or hilly area (cordillera, sierra). rapids - fast-flowing section of a stream, often shallow and with exposed rock or boulders ( $r$ iffle, ripple). reserve -- a tract of land set aside for a specific use (does include forests or civil divisions). reservoir -- artificially impounded body of water (lake, tank). ridge -- elevation with a narrow, elongated crest which can be part of a hill or mountain (crest, cuesta, escarpment, hogback, lae, rim, spur). school -- building or group of buildings used as an institution for study, teaching, and learning (academy, college, high school, university). sea -- large body of salt water (gulf, ocean). slope -- a gently inclined part of the Earth's surface (grade, pitch). spring -- place where underground water flows naturally to the surface of the Earth (seep).

stream -- linear body of water flowing on the Earth's surface (anabranch, awawa, bayou, branch, brook, creek, distributary, fork, kill, pup, rio, river, run, slough).

summit - - prominent elevation rising above the surrounding level of the Earth's surface; does not include pillars, ridges, or ranges (ahu, berg, bald, butte, cerro, colina, cone, cumbre, dome, head, hill, horn, knob, knoll, mauna, mesa, mesita, mound, mount, mountain, peak, puu, rock, sugarloaf, table, volcano).

swamp --- poorly drained wetland, fresh or saltwater, wooded or grassy, possibly covered with open water (bog, cienega, marais, marsh, pocosin). trail -- route for passage from one point to another; does not include roads or highways (jeep trail, path, ski trail). tower -- a manmade structure, higher than its diameter, generally used for observation, storage, or electronic transmission. tunnel -- linear underground passageway open at both ends. valley -- linear depression in the Earth's surface that generally slopes from one end to the other (barranca, canyon, chasm, cove, draw, glen, gorge, gulch, gulf, hollow, ravine).

well -- manmade shaft or hole in the Earth's surface used to obtain fluid or gaseous materials.

woods -- small area covered with a dense growth of trees; does not include an area of trees under the administration of a political agency (see forest). 


\section{APPENDIX F:-STANDARD CARTOGRAPHIC ABBREVIATIONS}

\begin{tabular}{|c|c|c|c|}
\hline Academy & Acad & Crater & $\operatorname{ctr}$ \\
\hline Agency & $\mathrm{Agcy}$ & Creek & $\mathrm{Cr}$ \\
\hline Air Force Base & AFB & Crossing & Xing \\
\hline Airfield & AfId & District & Dist \\
\hline Airport & Aprt & Ditch & D \\
\hline Anchorage & Anch & Divide & Div \\
\hline Aqueduct & Aque & Division & Div \\
\hline Arroyo & A & Dock & $\mathrm{Dk}$ \\
\hline Atoll & At & Dockyard & Dkyd \\
\hline Bank & Bk & Elevation & Elev \\
\hline Bay & B & Entrance & Entr \\
\hline Bayou & B & Estuary & Est \\
\hline Beacon & $\mathrm{Bn}$ & Ferry & Fy \\
\hline Bottom & Bot & Field & Fld \\
\hline Branch & $\mathrm{Br}$ & Flat & Fl \\
\hline Breakwater & Bkwr & Foot & Ft \\
\hline Bridge & $\mathrm{Br}$ & Ford & $\mathrm{Fd}$ \\
\hline Brook & Bk & Forest & For \\
\hline Building & Bldg & Fork & Fk \\
\hline Canal & Can & Fort & Ft \\
\hline Canyon & Can & Glacier & $\mathbf{G I}$ \\
\hline Cape & $\mathrm{C}$ & Grade & Gr \\
\hline Castle & Cas & Grant & Gt \\
\hline Cemetery & Cem & Gulch & G1 \\
\hline Channel & Chan & Gulf & Gf \\
\hline Chape 1 & $\mathrm{Ch}$ & Hammock & Hmk \\
\hline Chimney & Chy & High School & HS \\
\hline Church & $\mathrm{Ch}$ & Hollow & Hol \\
\hline Civil Division & $\mathrm{Civ}$ & Hook & $\mathrm{Hk}$ \\
\hline College & Col & Hospital & Hos \\
\hline Corner & Cor & Institute & Inst \\
\hline County & Co & Island (s) & I, Is \\
\hline Cove & C & Islet & It \\
\hline
\end{tabular}




\begin{tabular}{|c|c|c|c|}
\hline Isthmus & Isth & Shoal & $\operatorname{Shl}$ \\
\hline Jetty & Jty & siding & $\mathrm{Sdg}$ \\
\hline Junction & Junc & slough & slu \\
\hline Lagoon & $\operatorname{Ln}$ & Spring & Spr \\
\hline Lake (s) & L & Square & $\mathrm{sq}$ \\
\hline Land Grant & Ld Gt & Station & sta \\
\hline Landing & $\mathrm{Ldg}$ & Strait & str \\
\hline Landing Field & Ldg Fld & Stream & str \\
\hline Landing Strip & Ldg Str & Terrace & Ter \\
\hline Lighthouse & $\mathrm{LH}$ & Thorofare & Thoro \\
\hline Lookout & LO & Tidal Flat & Tid $\mathrm{F} 1$ \\
\hline Meadow & Mdw & Tower & $\operatorname{Tr}$ \\
\hline Monument & Mon & Township & Twp \\
\hline Mount & Mt & Track & Tk \\
\hline Mountain & Mtn & Tributary & Trib \\
\hline Mountains & Mts & University & Univ \\
\hline Ocean & 0 & Valley & Val \\
\hline Park & $\mathrm{Pk}$ & viaduct & Viad \\
\hline Passage & Pass & Village & vil \\
\hline Peak & $\mathbf{P k}$ & Volcano & Volc \\
\hline Peninsula & Pen & Wharf & Whe \\
\hline Plateau & Plat & Windmill & WM \\
\hline Point & Pt & Yard & Yd \\
\hline Pond & Pd & & \\
\hline Projection & Proj & & \\
\hline Promontory & Prom & & \\
\hline Quarry & Qry & & \\
\hline Range & $\mathbf{R}$ & & \\
\hline Ravine & Rav & & \\
\hline Reef & Rf & & \\
\hline Refuge & $\mathrm{Rfg}$ & v & \\
\hline Reservoir & Res & & \\
\hline River & $\mathbf{R}$ & & \\
\hline Rock & $\mathbf{R d}$ & & \\
\hline Run & $\mathbf{R}$ & & \\
\hline School & Sch & & \\
\hline
\end{tabular}




\section{APPENDIX G:-GEOGRAPHIC NAMES INFORMATION SYSTEM \\ MAP FEATURE GUIDE}

(* indicates diacritical mark missing)

GENERIC/WORD

FEATURE
CLASS

Aa

Ac ademy

Acclivity

Acequia

Addition

Adert

Adit

Agency

Agua

Ahu

Aiguille

Air Facility

Air Force Base

Air station

Airfield

Airport

Airstrip

Aisle

Alcove

Alluvial Fan

Alluvium

Alto

Ammunition Depot

Ammunition Plant

Amphibious Base

Amphitheater

Anabranch

Anchorage

Aquafact

Aqueduct

Arboretum

Arch

Archipelago

Area

Arete *

Arm

Army Depot

Army Headquarters

Army Post

Arroyo

Arsenal

Ato 11

Awawa

Backbone lava

school

slope

canal

locale

slope

mine

locale

stream

summit

pillar

military

military

military

airport

airport

airport

gap

cave

area

area

summit

military

military

military

bas in

stream

harbor

pillar

canal

park

arch

is land

area

ridge

bay

military

military

military

arroyo

military

is land

stream

ridge
SOURCE

POINT

REQ

center

center

center

center

center

center

center

center

mouth

top

top

center

center

center

center

center

center

center

center

center

center

top

center

center

center

center

mouth

center

top

center

center

center

center

center

center

center

center

center

center

mouth

center

center

mouth

center yes

yes

yes

yes 


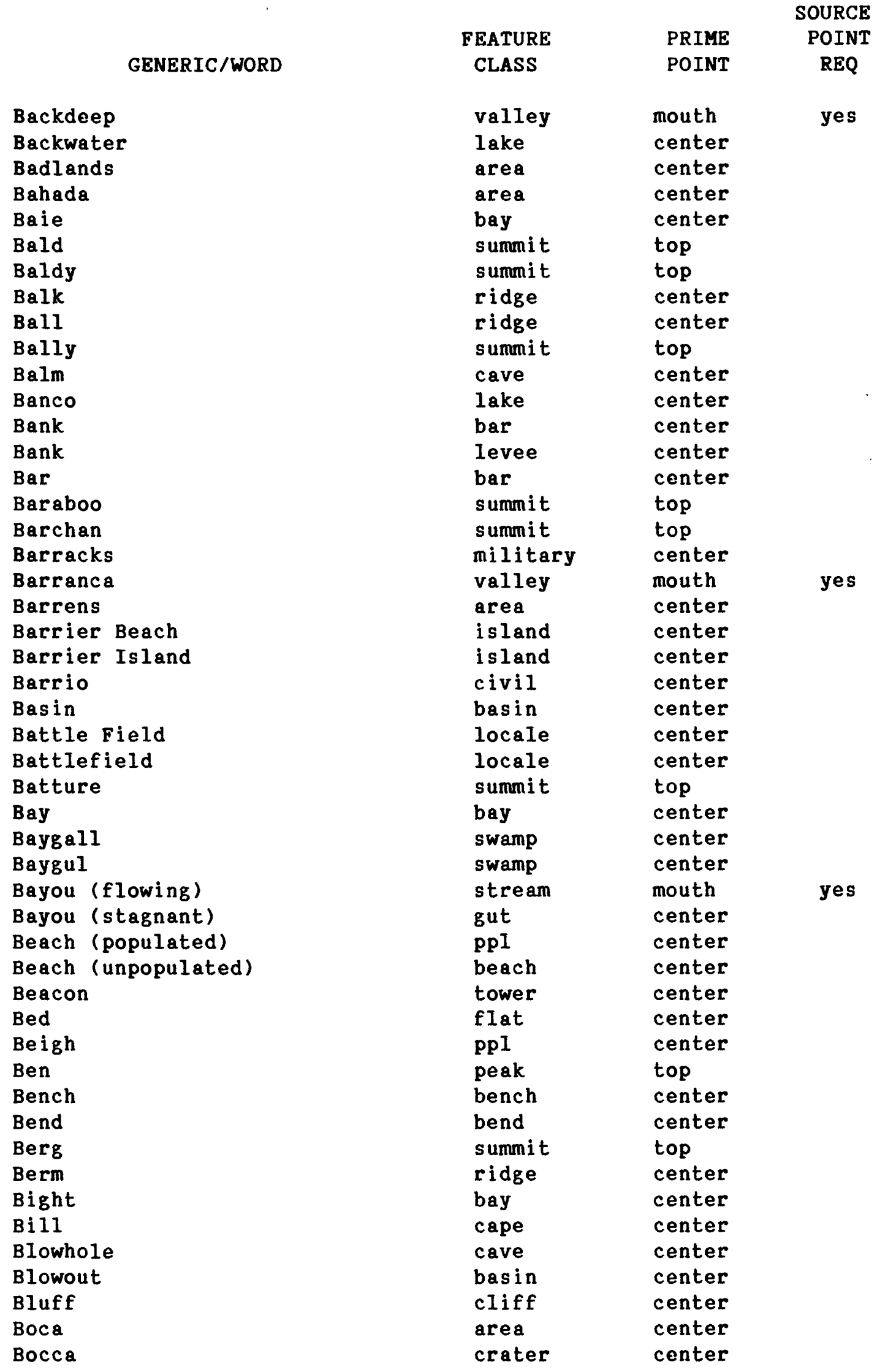




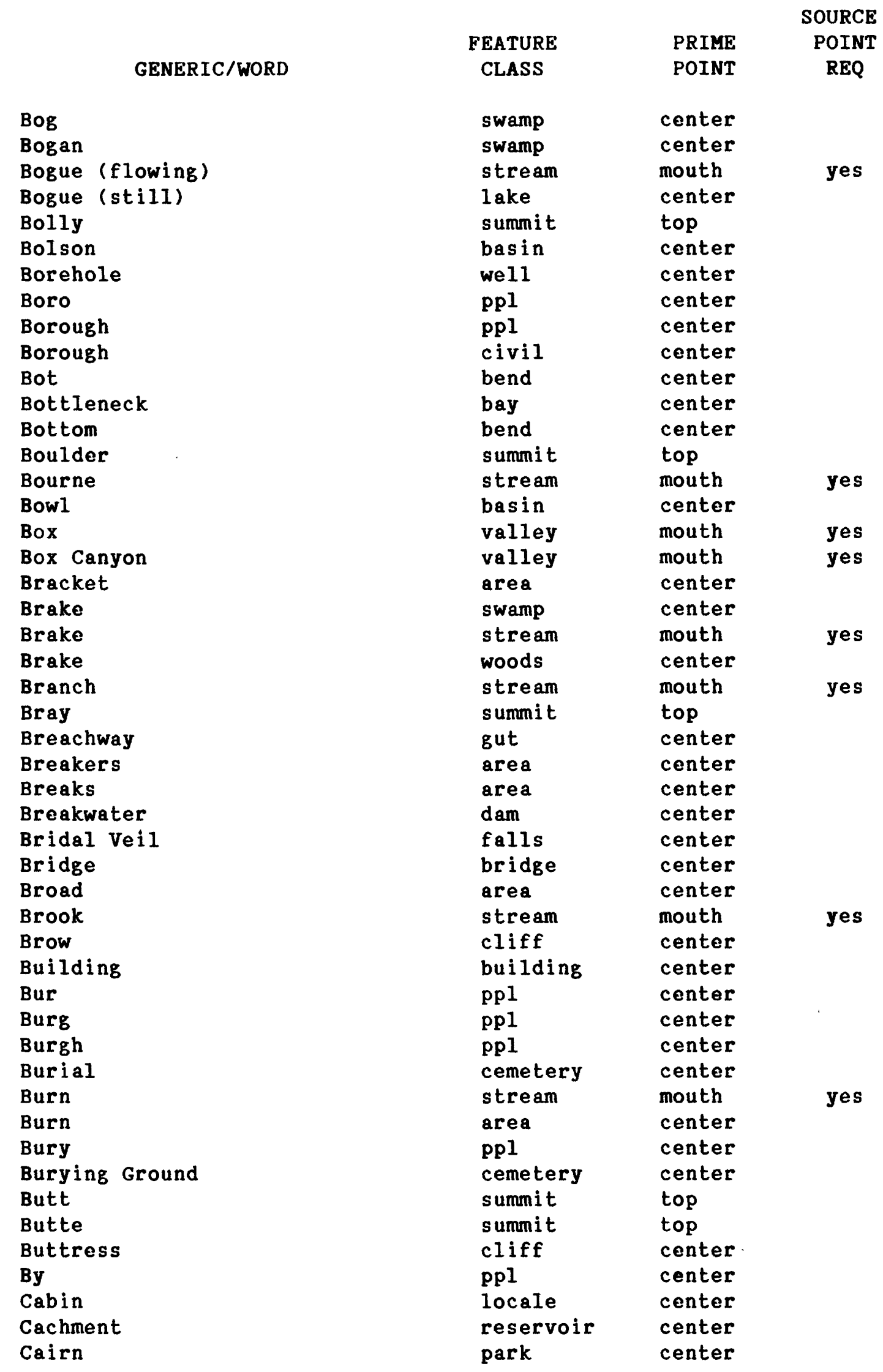




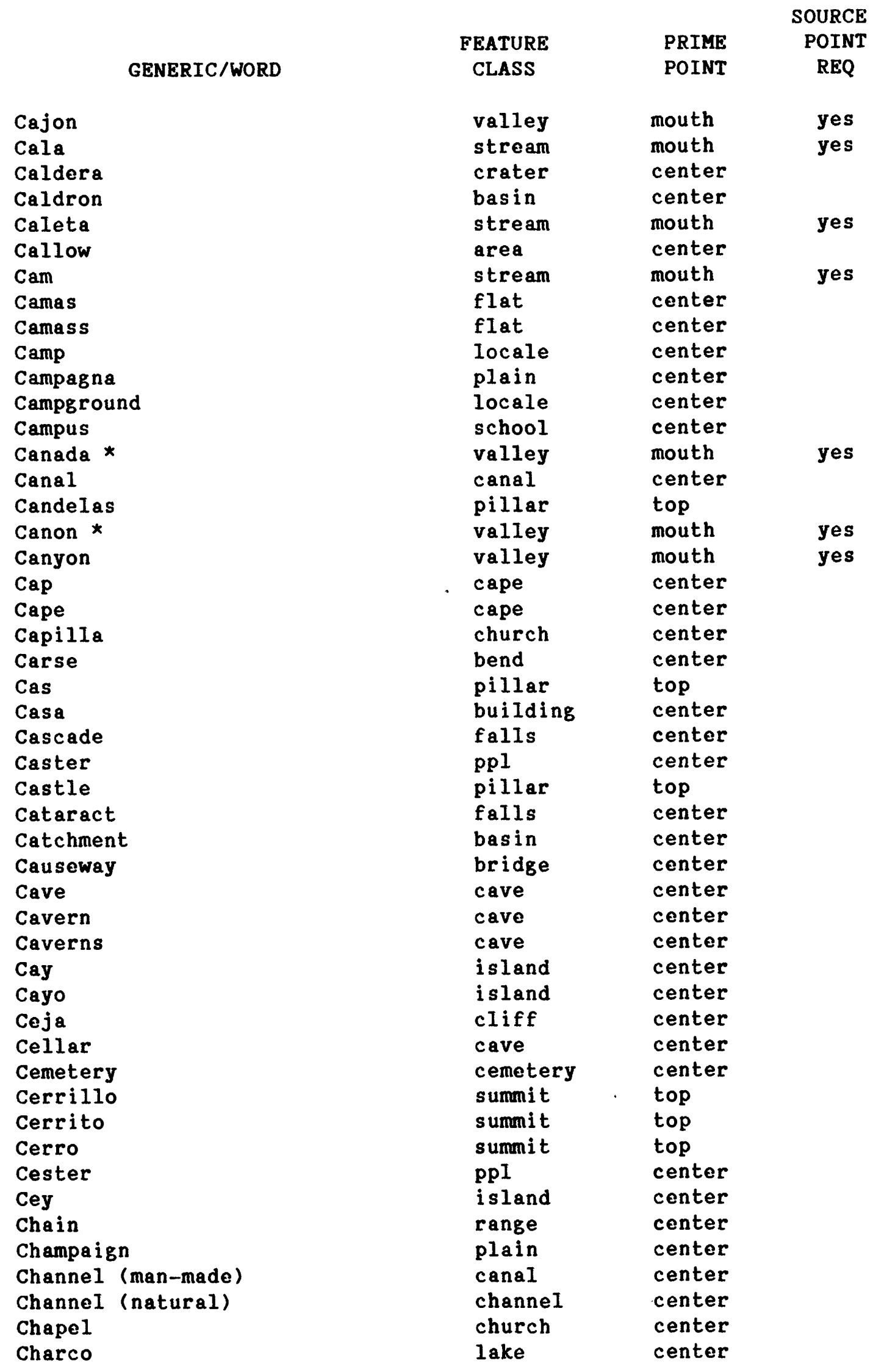




\begin{tabular}{|c|c|c|c|}
\hline & FEATURE & PRIME & $\begin{array}{r}\text { SOURCE } \\
\text { POINT }\end{array}$ \\
\hline GENERIC/WORD & CLASS & POINT & REQ \\
\hline Chasm & valley & mouth & yes \\
\hline Chester & pp1 & center & \\
\hline Chimney & pillar & top & \\
\hline Chine & valley & mouth & yes \\
\hline Chuck & bay & center & \\
\hline Church & church & center & \\
\hline Chute & stream & mouth & yes \\
\hline Chute & channel & center & \\
\hline Chute & gut & center & \\
\hline Cienaga & swamp & center & \\
\hline Cinder & summit & top & \\
\hline Cirque & basin & center & \\
\hline Cistern & reservoir & center & \\
\hline City (administrative) & civil & center & \\
\hline City (populated place) & pp1 & center & \\
\hline Civil Division & civil & center & \\
\hline Claim & civil & center & \\
\hline Clearing & flat & center & \\
\hline Cleft & valley & mouth & yes \\
\hline Cleuch & valley & mouth & yes \\
\hline Cleugh & valley & mouth & yes \\
\hline Cliff &.$c l i f f$ & center & \\
\hline clint & flat & center & \\
\hline Clove & valley & mouth & yes \\
\hline Cluse & valley & mouth & yes \\
\hline Coast & beach & center & \\
\hline Coast Guard Base & military & center & \\
\hline Coast Guard Lifeboat station & military & center & \\
\hline Coastline & beach & center & \\
\hline & $\begin{array}{l}\text { gap } \\
\text { summit }\end{array}$ & $\begin{array}{l}\text { center } \\
\text { top }\end{array}$ & \\
\hline Collado & summit & top & \\
\hline College & school & center & \\
\hline Colline & summit & top & \\
\hline Column & pillar & top & \\
\hline Comb & ridge & center & \\
\hline Combe & valley & mouth & yes \\
\hline Common & park & center & \\
\hline Community & ppl & center & \\
\hline Cone & summit & top & \\
\hline Confluence & bend & center & \\
\hline Constriction & gap & center & \\
\hline Coombe & valley & mouth & yes \\
\hline Cordillera & range & center & \\
\hline Corner & ppl & center & \\
\hline Corner & locale & center & \\
\hline Corners & locale & center & \\
\hline Corral & locale & center & \\
\hline Corrider. & gap & center & \\
\hline
\end{tabular}




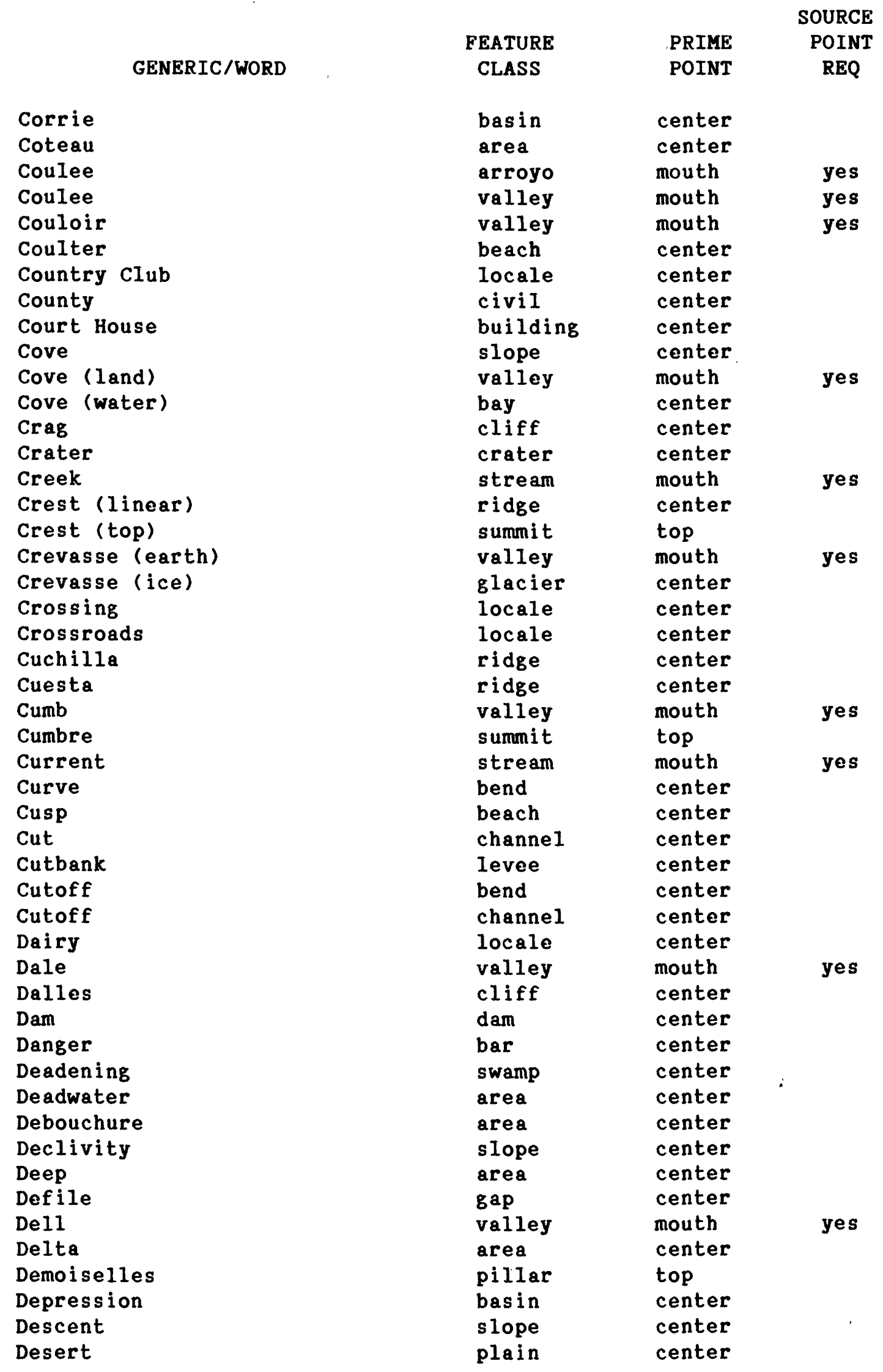




\begin{tabular}{|c|c|c|c|}
\hline \multirow[b]{2}{*}{ GENERIC/WORD } & FEATURE & PRIME & $\begin{array}{r}\text { SOURCE } \\
\text { POINT }\end{array}$ \\
\hline & CLASS & POINT & REQ \\
\hline Dike & levee & center & \\
\hline Dingle & valley & mouth & yes \\
\hline Dismal & swamp & center & \\
\hline Distributary & stream & mouth & yes \\
\hline District & civil & center & \\
\hline Ditch & canal & center & \\
\hline Divide & ridge & center & \\
\hline Division & civil & center & \\
\hline Doab & cape & center & \\
\hline Dock & locale & center & \\
\hline Dockyard & locale & center & \\
\hline Dol & valley & mouth & yes \\
\hline Dolina & basin & center & \\
\hline Doline & basin & center & \\
\hline Dome & summit & top & \\
\hline Donga & valley & mouth & yes \\
\hline Down & flat & center & \\
\hline Downs & locale & center & \\
\hline Draft & valley & mouth & yes \\
\hline Dragway & locale & center & \\
\hline Drain (man-made) & canal & center & \\
\hline Drain (naturaI) & stream & mouth & yes \\
\hline Draw (deep) & valley & mouth & yes \\
\hline Draw (shailow) & arroyo & mouth & yes \\
\hline Drift & summit & top & \\
\hline Drop & falls & center & \\
\hline Drum & summit & top & \\
\hline Drumlin & summit & top & \\
\hline Drumlinoid & summit & top & \\
\hline Drumloid & summit & top & \\
\hline Drywash & arroyo & mouth & yes \\
\hline Dugout & channel & center & \\
\hline Dun & summit & top & \\
\hline Dune & summit & top & \\
\hline Dustwe 11 & basin & center & \\
\hline Dwip & summit & top & \\
\hline Eddy & rapids & center & \\
\hline Eddy & bay & center & \\
\hline Elbow & bend & center & \\
\hline Elevation & summ it & top & \\
\hline Embankment & levee & center & \\
\hline Embayment & bay & center & \\
\hline Embouchure & area & center & \\
\hline Eminence & summit & top & \\
\hline Entrance & gut & center & \\
\hline Erg & plain & center & \\
\hline Escarpment & cliff & center & \\
\hline Esker & ridge & center & \\
\hline Estate & locale & center & \\
\hline
\end{tabular}




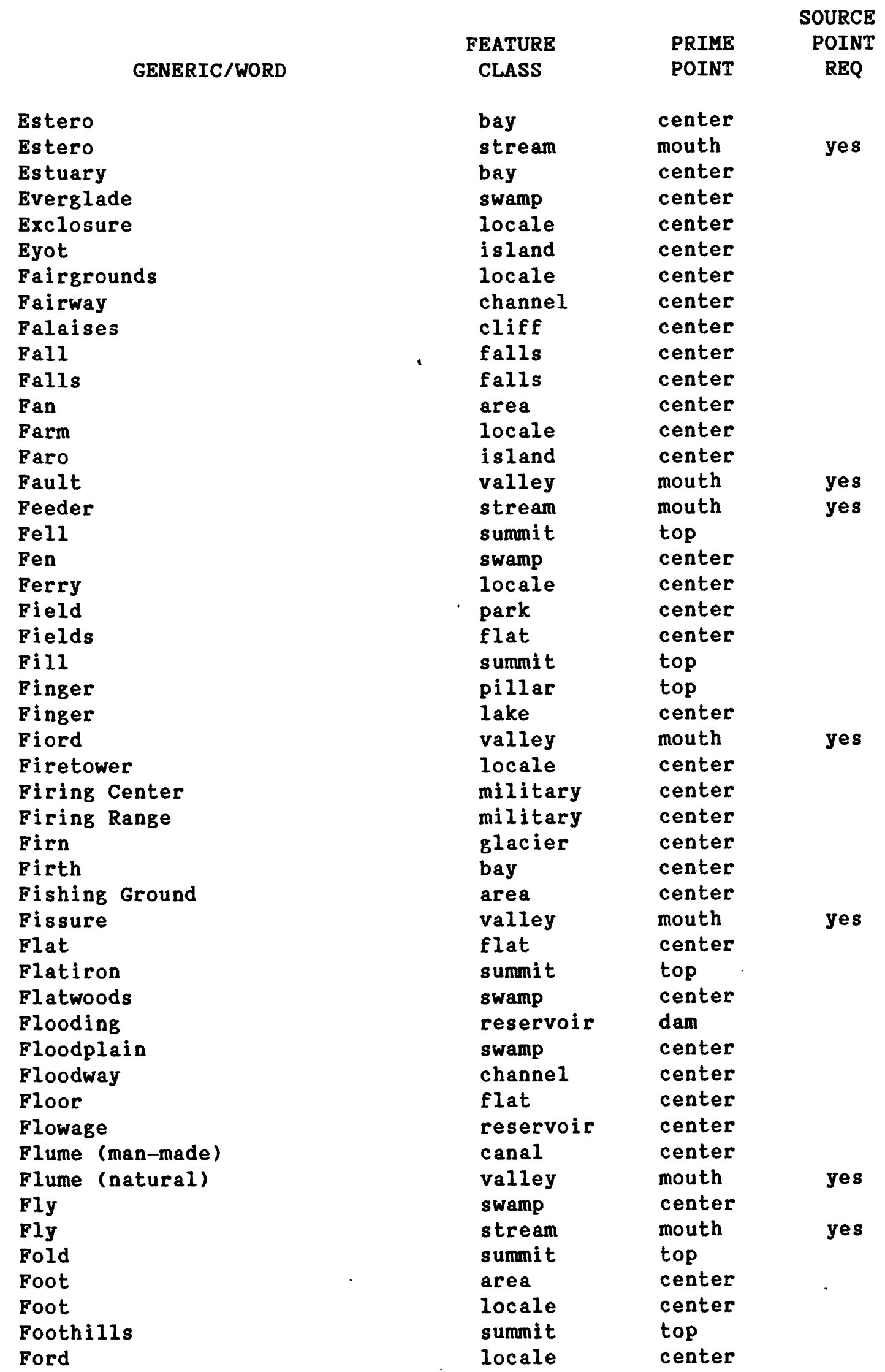




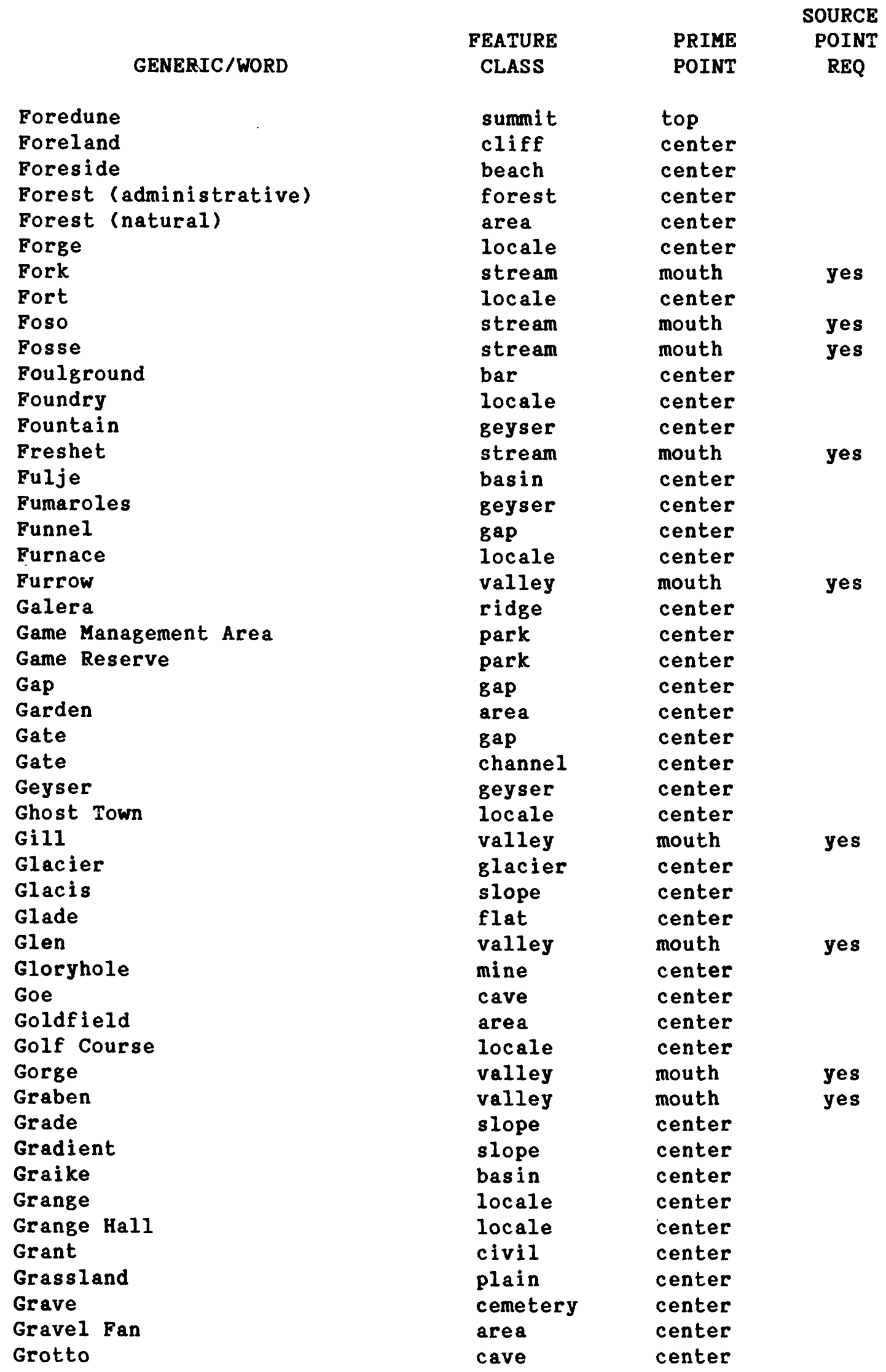




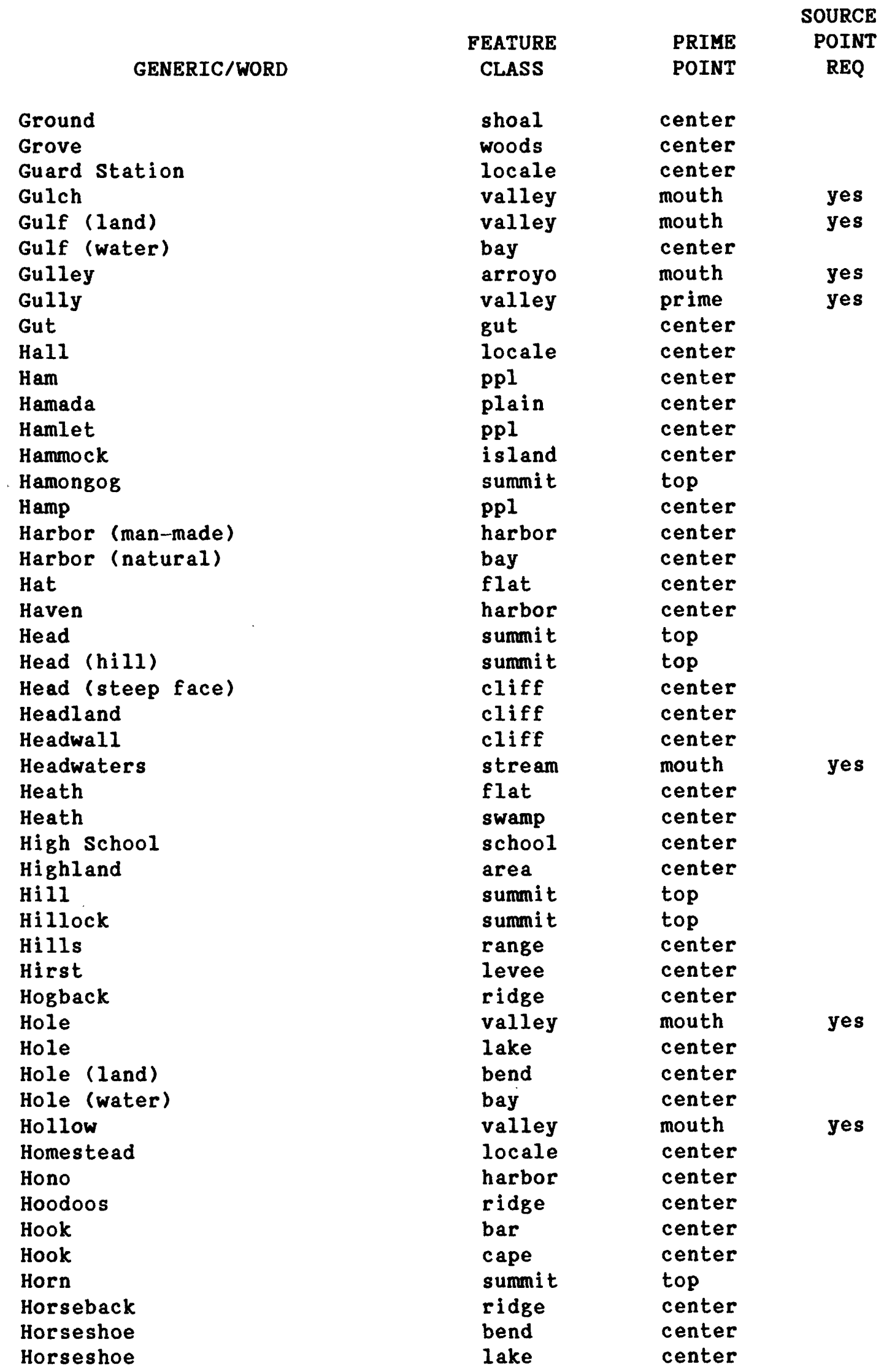


FEATURE

CLASS

Horst

Hospital

Hot Spring

Huerfano

Hum

Hummock

Hump

Hurst

Ice Patch

Icecap

Icefal1

Icefield

Icesheet

Indian Reservation

Inf i rmary

Inlet

Inlet (channel)

Inlet (water body)

Inn

Inst itute

Intercolline

Interfluve

Intervale

Intervale

Island (s)

Isle

Islet

Isthmus

$J$ ambs

Jeep Trail

Jetty

Jumpof $f$

Junction

Kame

Kar

Karroo

Karst

Keana

Kernbut

Kettle

Kettlehole

Key

$\mathrm{Ki} I 1$

Ki puka

Ki puka

Kirk

Knob

Knol1

Kula summit

hospital

spring

summit

summit

i sland

summit

summit

glacier

glacier

glacier

glacier

glacier

reserve

hospital

stream

gut

bay

locale

school

gap

swamp

swamp

bas in

island

i sland

i sland

isthmus

valley

trail

dam

cliff

locale

summit

basin

plain

area

cave

summit

basin

basin

island

stream

is 1 and

lava

church

s ummit

summit

plain
SOURCE

POINT

REQ

top

center

center

top

top

center

top

top

center

center

center

center

center

center

center

mouth

center

center

center

center

center

center

center

center

center

center

center

center

mouth

center

center

top

center

top

center

center

center

center

top

center

center

center

mouth

center

center

center

top

top

center 


\section{FEATURE}

CLASS

Lac

Lae

Lae

Lagoon (open water)

Lagoon (vegetation)

Laguna

Lake (s)

Lakebed

Land Grant

Landf $\mathrm{a} 11$

Landing

Landing Field

Landing strip

Landslide

Landslip

Lateral

Lava

Lava Cone

Lava Delta

Lava Field

Lava Flow

Lava Pit

Lava Plain

Lava Plateau

Lava Tongue

Lava Tube

Lea

Leach Hole

Lead

Ledge ( 1 and)

Ledge (water)

Lenticular

Levee

Leve1

Lick

Lick

Lighthouse

Littoral

LIano

Locale (little or no population)

Locality

Loch

Logan

Loma

Loma

Longshore Bar

Lookout

Loop

Loop Lake lake

cape

ridge

lake

swamp

lake

lake

flat

civil

slope

locale

airport

airport

slope

slope

canal

lava

lava

lava

lava

lava

crater

lava

lava

lava

lava

plain

cave

ridge

bench

bar

summ it

levee

flat

stream

area

locale

beach

area

locale

locale

lake

swamp

summit

summit

bar

locale

bend

lake
SOURCE

POINT

REQ

center

center

center

center

center

center

center

center

center

center

center

center

center

center

center

center

center

center

center

center

center

center

center

center

center

center

center

center

center

center

center

top

center

center

mouth

center

center

center

center

center

center

center

center

top

top

center

center

center

center 
Lough

Lowl and

Lowmoor

Lua

Lump

Lunatt

Maar

Malaspina

Malpais

Mamelon

Mangrove

Mar

Marais

Mareman

Marina

Marine Corps Air Station

Marine Corps Base

Market

Marsh

Mass

Mass if

Matterhorn

Mauna

Meadow

Meander

Meander Core

Medano

Meet inghouse

Memorial Garden

Mendip

Mer

Mes a

Meseta

Mesita

Mesita

Midway

Military Reservation

Mill

Millpond

Milltown

Mine

Mire

Missile Base

Missile Range

Mission

Mofette

Moku

Mole

Monadnock lake

flat

swamp

crater

is land

bar

crater

glacier

area

summit

swamp

sea

swamp

swamp

locale

military

military

locale

swamp

summit

range

summit

summit

flat

bend

bend

summit

church

cemetery

summit

sea

summit

summit

summit

summit

channel

military

locale

reservoir

locale

mine

swamp

military

military

church

valley

is land

dam

summit center

center

center

center

center

center

center

center

center

top

center

center

center

center

center

center

center

center

center

top

center

top

top

center

center

center

top

center

center

top

center

top

top

top

top

center

center

center

dam

center

center

center

center

center

center

mouth

center

center

top 
FEATURE

CLASS

Monastery

Monolith

Mont

Monte

Monticle

Monticule

Monument

Monument

Hoor

Mor

Moraine (area)

Moraine (1inear)

Morais

Morass

Moremma

Morriner

Mosque

Mott

Mott

Motte

Motte

Moulin

Hound

Mount

Mountain

Mountain Chain

Mountain Group

Mountain Range

Mountain System

Mountains

Mountainside

Mouth

Mud Cone

Mud Flat

Mud Pot

Mudflow

Mu11

Municipality

Municipio *

Muskeg

Narrow

Narrows

Narrows

Narrows

Natatorium

National Forest

National Grasslands

National Historical Landmark

National Monument pillar

summit

summit

crater

crater

pillar

park

flat

flat

summit

ridge

swamp

swamp

swamp

ridge

church

summit

woods

summit

cliff

glacier

summit

summit

summit

range

range

range

range

range

cliff

area

summit

flat

spring

slope

cape

civil

civil

swamp

pass

gap

ridge

channel

locale

forest

forest

park

park church
PRIME

POINT

SOURCE

POINT

REQ center

top

top

top

center

center

top

center

center

center

top

center

center

center

center

center

center

top

center

top

top

center

top

top

top

center

center

center

center

center

center

center

top

center

center

center

center

center

center

center

center

center

center

center

center

center

center

center

center 


\section{FEATURE}

CLASS

National Park (administrative)

National Seashore

National Wilderness Area

National Wildlife Area

Natural Bridge

Naval Air Station

Naval Base

Naval Shipyard

Naze

Neck

Needle

Ness

Neve *

Niche

Nip

Nipple(s)

Nobble

Nose

Nose

Notch

Notch

Nubble

Nubble

Nullah

Nunatak

Oas is

Ocean

offset

Offshore Bar

0il Pumping station

oilfield

Oilwell

ojito

ojo

Open

Open Bay

Orchard

Ordinary

Ordnance Laboratory

Ordnance Plant

Os

Osar

Outcrop

outlet

Outlet

Outwash

Overfall

Overhang

overlook park

park

park

park

arch

military

military

military

cliff

cape

pillar

cape

glacier

cave

cave

summit

summit

cliff

summ it

gap

channel

summit

island

valley

summit

spring

sea

ridge

bar

oilfield

oilfield

wel1

spring

spring

flat

bay

locale

locale

military

military

ridge

ridge

s ummit

channe 1

stream

plain

rapids

cliff

locale
SOURCE

POINT

REQ

center

center

center

center

center

center

center

center

center

center

top

center

center

center

center

top

top

center

top

center

center

top

center

mouth

top

center

center

center

center

center

center

center

center

center

center

center

center

center

center

center

center

center

top

center

mouth

center

center

center

center 


\section{FEATURE}

CLASS

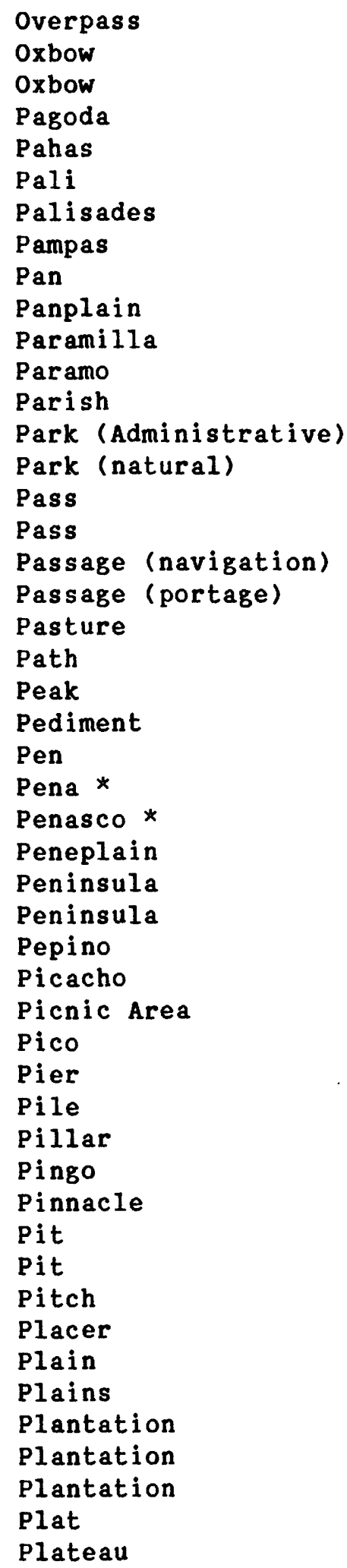

bridge

bend

lake

church

summit

cliff

cliff

plain

flat

plain

range

area

civil

park

flat

gap

channe1

channel

locale

flat

trail

summit

slope

locale

pillar

pillar

plain

cape

cape

summit

summit

locale

summit

locale

summit

pillar

summit

pillar

bas in

mine

slope

area

plain

plain

ppl

locale

civil

plain

plain
SOURCE

POINT

REQ center

center

center

center

top

center

center

center

center

center

center

center

center

center

center

center

center

center

center

center

center

top

center

center

top

top

center

center

center

top

top

center

top

center

top

top

top

top

center

center

center

center

center

center

center

center

center

center

center 


\section{FEATURE \\ CLASS}

Platform

Playa

Plaza (cultural)

Plaza (physical)

Pocket

Pocosin

Pohaku

Point

Point

Point (penifsula)

Point (promontory)

Polder

Polje

Polye

Pond (man-made)

Pond (natural)

Ponor

Pool (man-made)

Pool (natural)

Port

Port

Port of Entry

Portage

Portal

Portal

Portal

Pothole

Potrero

Pozo

PPL (Populated Place)

Prairie

Precinct

Precipice

Projection

Promontory

Prong

Puerta

Puertecito

Puerto

Puerto (Iand)

Puerto (water)

Puffing Hole

Punta

Pup

Puragatory

Puu

Quagmire

Quaking Bay

Quarry

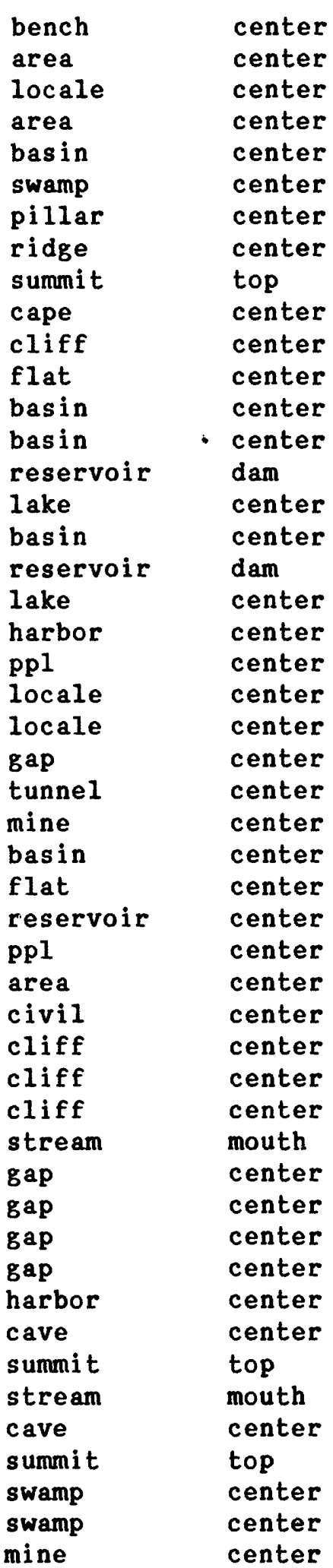

SOURCE

POINT

REQ 


\section{FEATURE}

CLASS

Quarry

Quartermaster Depot

Quay

Quebrada

Race

Race

Railroad Siding

Railroad Station

Railroad Stop

Rainpool

Ramble

Ranch

Ranch

Rancho

Range

Range

Rapids

Ravine

Razorback

Reach

Recreation Site

Reef

Reef

Reentrant

Refuge

Reg

Remnant

Resaca

Research Station

Reserve

Reserve

Reserve

Reserve Training Center

Reservoir

Resort

Retention Basin

Retreat

Revetment

Ria

Ridge

Riffle

Rift

Ri 11

Rim

Rimrock

Rincon

Rio

Rip

Ripple

\section{basin}

military

locale

valiey

stream

area

locale

building

Iocale

Iake

valley

locale

slope

civil

range

channel

rapids

valley

ridge

area

locale

ridge

bar

bend

park

plain

summ it

lake

locale

park

forest

reserve

military

reservoir

ppI

reservoir

Iocale

levee

bay

ridge

rapids

valley

stream

cIiff

cliff

valley

stream

area

rapids
SOURCE

POINT

REQ

yes

yes

yes

mouth

center

center

center

center

center

center

mouth

center

center

center

center

center

center

center

center

top

center

center

center

center

center

center

dam

center

center

center

center

center

center

center

mouth

mouth

center

center

mouth

mouth

center

center yes

yes

yes

yes 


\section{FEATURE \\ CLASS}

Rips

Rito

River

River Basin

River Bed

River Bottom

River Valley

Riveret

Riviere *

Rivulet

Roads

Roadstead

Roche Moutonnee

Rock

Rock

Rock (massive)

Rock (singular)

Rock slide

Rock Tower

RockfalI

Rodeo Grounds

Rognon

Rookery

Rough

Ruins

Run

Runnel

Saddle

Saddleback

Sag

Sagpond

Salient

Salina

Salt Bottom

Salt Flat

Salt Lick

Salt Marsh

Salt Prairie

Saltpan

Salturn

Sanctuary

Sand

Sand Drift

Sand Dune

Sand Flat

Sandbank

Sandbar

Sandia

Sandkey rapids

stream

stream

bas in

channel

bend

valley

stream

stream

stream

bay

harbor

summit

bar

is land

summit

pillar

slope

pillar

slope

locale

summit

is land

ridge

locale

stream

stream

gap

ridge

gap

lake

ridge

flat

flat

flat

flat

flat

flat

flat

flat

park

beach

summit

flat

bar

bar

summit

is land summit
SOURCE

POINT

REQ

center

mouth

yes

mouth yes

center

center

center

mouth

yes

yes

mouth yes
mouth yes

center

center

top

center

center

top

top

center

center

center

center

top

center

center

center

mouth

mouth

center

center

center

center

center

center

center

center

center

center

center

center

center

center

center

top

top

center

center

center

top

center 


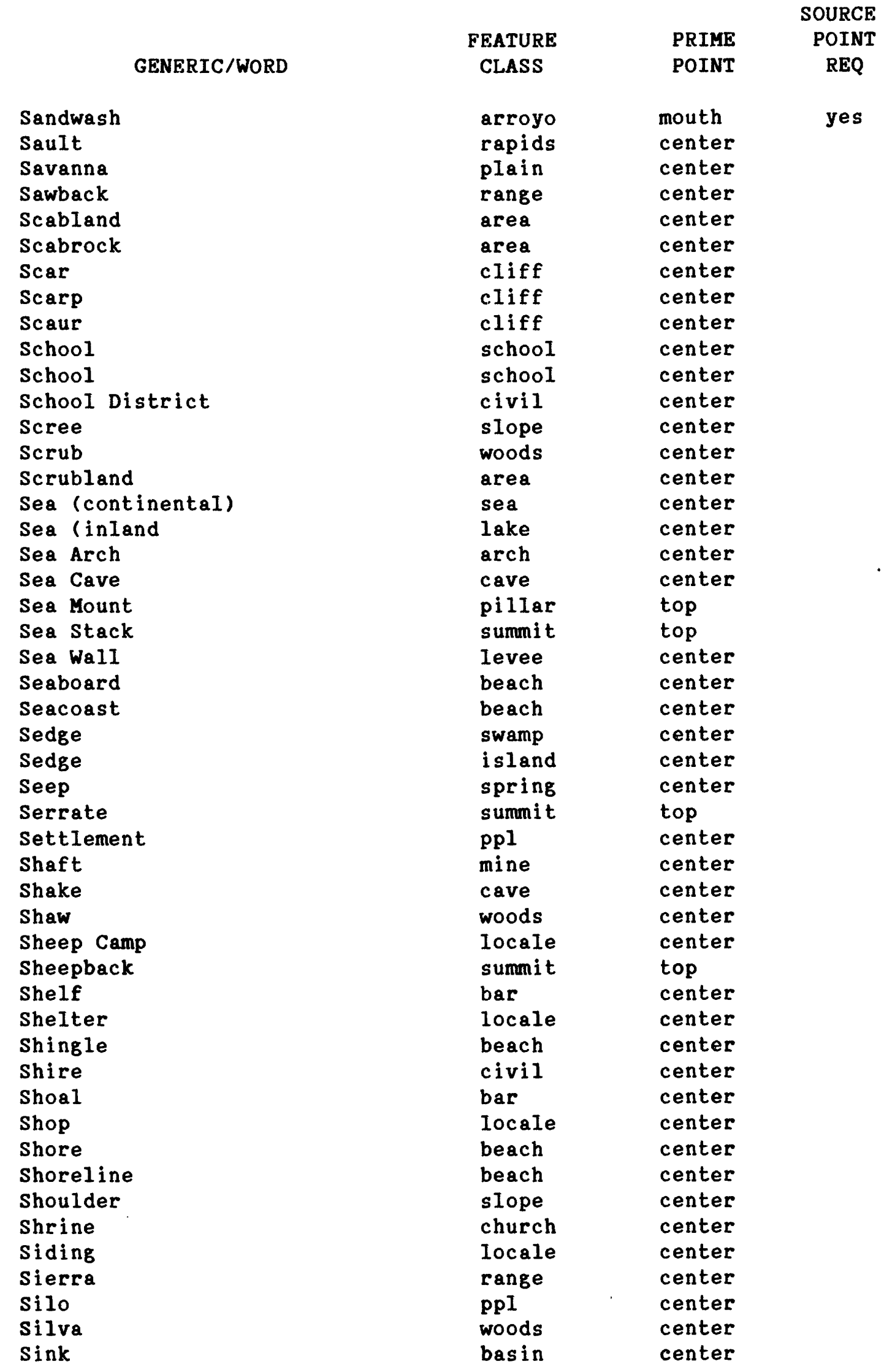




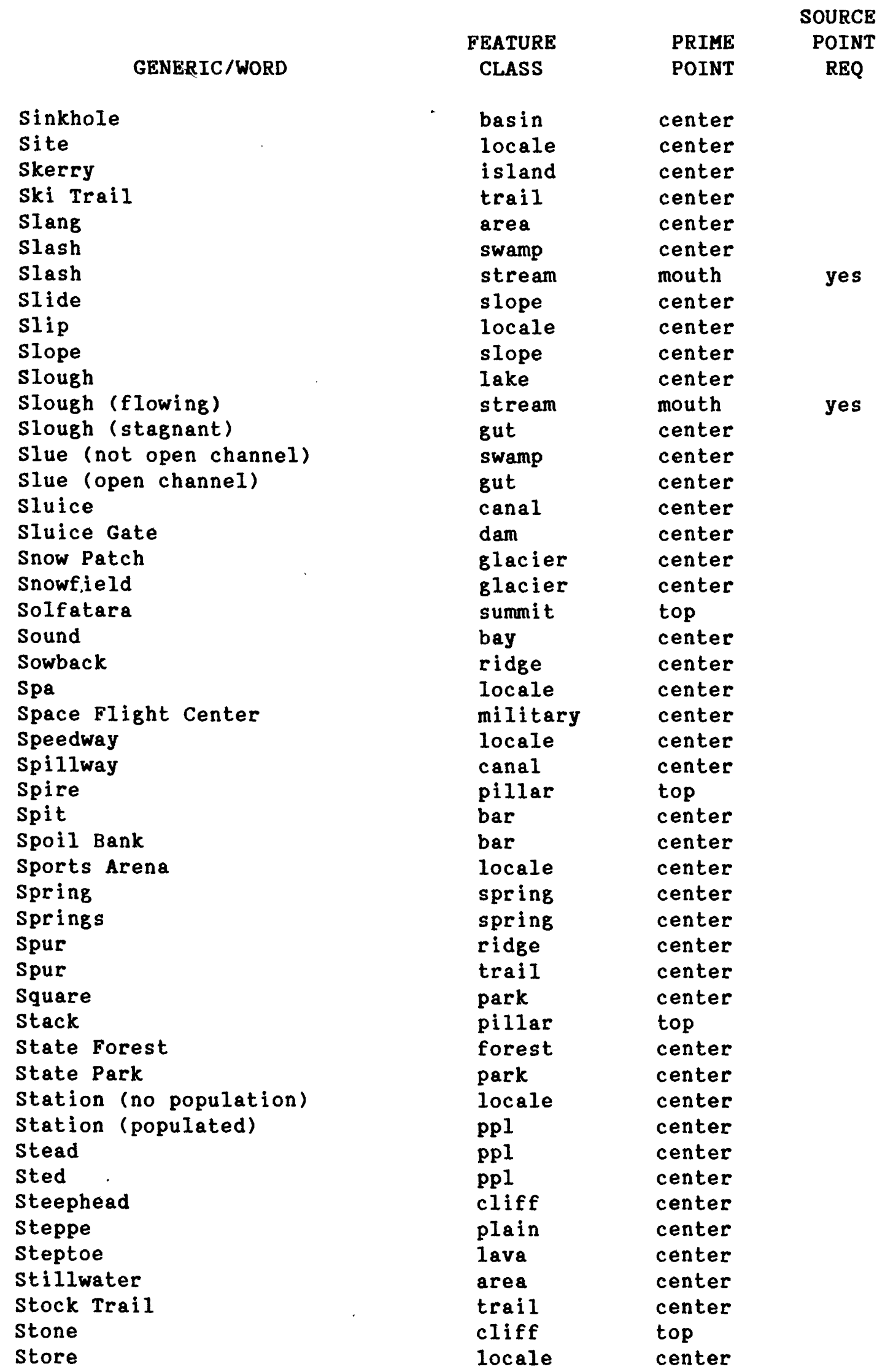


FEATURE

CLASS

Strait

Strand

Strand

Strath

Stream

Stretch

Stringer

Subsidence

suburb

Suck

Sugar Loaf

Sugarloaf

Summit (cuItural)

Summit (physical)

Supply Center

Supply Depot

Swag

Swale

Swallow

Swallow Hole

Swamp

Swamp

Swash

Synagogue

Tabernacle

Table

Table Mountain

Tableland ( $3 \mathrm{mi}$. across)

Tableland (- $3 \mathrm{mi}$. across)

Taiga

Talus

Tank

Tanque

Tarai

Tarn

Tavern

Teat

Temple

Ten

Tepee

Terrace

Terrain

Terrane

Terrene

Test Center

Test Range

Teton

Thalweg

Thicket
channeI

beach

swamp

flat

stream

channel

stream

bas in

ppI

swamp

summit

summit

locale

summit

mi.litary

military

gap

valley

basin

cave

swamp

stream

bar

church

church

summit

summit

area

summit

woods

slope

reservoir

reservoir

swamp

lake

locale

summit

church

ppI

pillar

bench

plain

plain

plain

military

military

summit

valley

woods
SOURCE

POINT

REQ

yes

yes

mouth

center

center

center

top

top

center

top

center

center

center

mouth

center

center

center

mouth

center

center

center

top

top

center

top

center

center

dam

center

center

center

center

top

center

center

top

center

center

center

center

center

center

top

mouth

center 
FEATURE

CLASS

Thorofare

Thorofare

Thoroughfare

Thoroughfare

Thorpe

Throat

Thrumcap

Thumb

Thurm

Thwaite

Tickle

Tidal Creek

Tidal Flat

Tidal Inlet

Tidal Marsh

Tideland

Tiderace

Tie

$\mathrm{Tin}$

Tipple

Tit(s)

Toe

Toe

Toll House

Tombolo

Ton

Tongue

Tooth

Top

Top

Tor

Torrent

Tower

Tower (+500 ft. across)

Tower ( $500 \mathrm{ft}$. across)

Towhead

Town

Town (populated place)

Township

Trace

Trace

Track

Trail

Transverse

Trench

Trestle

Tributary

Trough

Tule channel

gut

gap

channel

ppI

stream

island

pillar

cliff

flat

gut

gut

flat

gut

swamp

flat

stream

bar

ppl

locale

summit

cape

summit

Iocale

isthmus

ppl

cape

pillar

summit

cape

summit

rapids

tower

s ummit

pillar

island

civil

ppI

civil

trail

stream

trail

trail

valiey

valley

bridge

stream

valley

swamp
SOURCE

POINT

REQ

yes

mouth

center

top

center

center

center

center

center

center

center

center

mouth

yes

center

center

center

top

center

top

center

center

center

center

top

top

center

top

center

center

top

top

center

center

center

center

center

mouth

center

center

mouth

mouth

center

mouth

mouth

center 


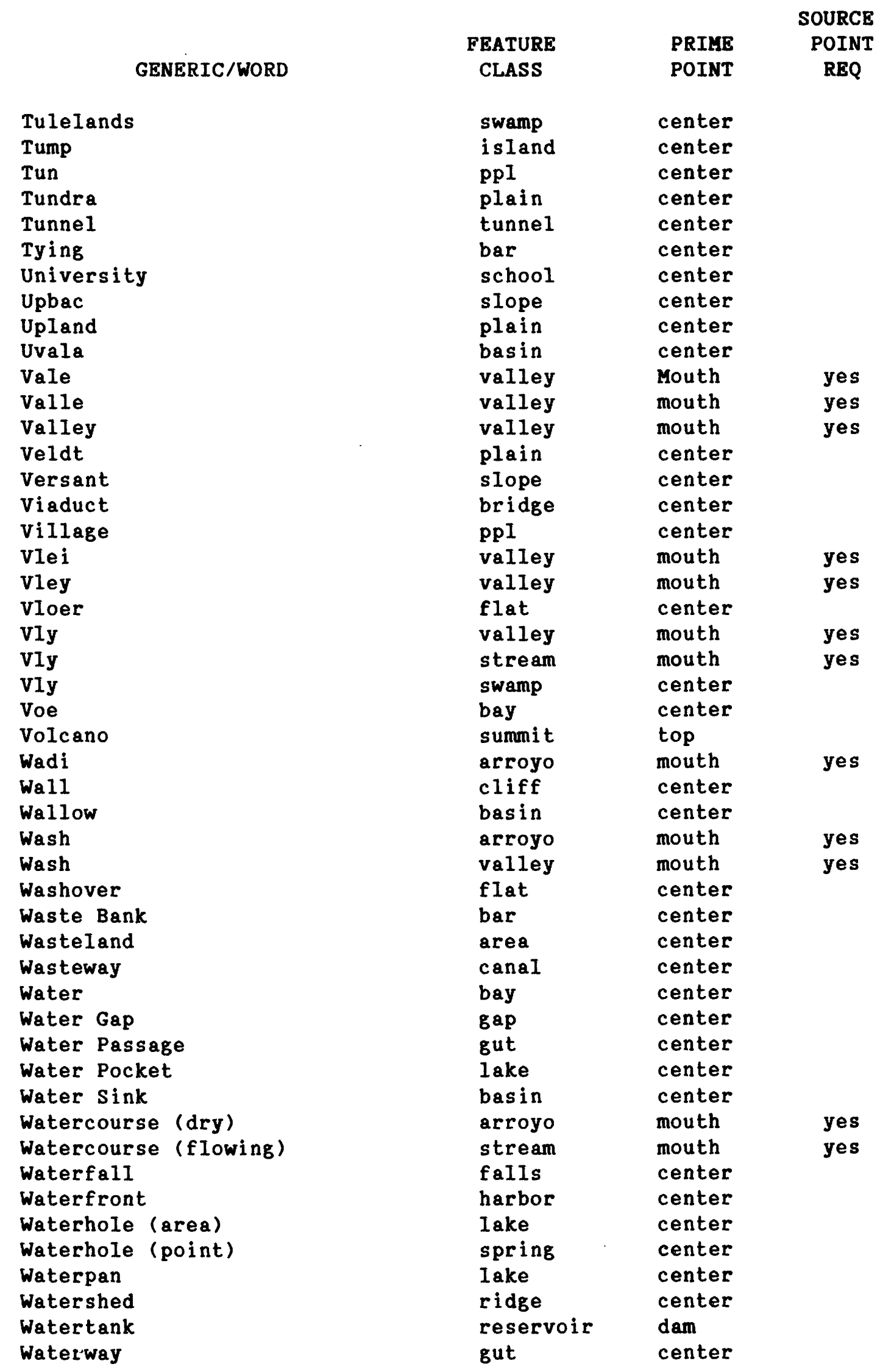




\begin{tabular}{|c|c|c|c|}
\hline GENERIC/WORD & $\begin{array}{l}\text { FEATURE } \\
\text { CLASS }\end{array}$ & $\begin{array}{l}\text { PRIME } \\
\text { POINT }\end{array}$ & $\begin{array}{c}\text { SOURCE } \\
\text { POINT } \\
\text { REQ }\end{array}$ \\
\hline $\begin{array}{l}\text { Waterway } \\
\text { Wayside } \\
\text { Weapons Range } \\
\text { Well } \\
\text { Wetland } \\
\text { Whaleback } \\
\text { Wharf } \\
\text { Whirlpool } \\
\text { Wich } \\
\text { Wick } \\
\text { Wind Gap } \\
\text { Windmill } \\
\text { Winged Headland } \\
\text { Woodland } \\
\text { Woods } \\
\text { Worth } \\
\text { Yacht Club } \\
\text { Yard } \\
\text { Yardang }\end{array}$ & $\begin{array}{l}\text { channel } \\
\text { locale } \\
\text { military } \\
\text { well } \\
\text { flat } \\
\text { summit } \\
\text { locale } \\
\text { rapids } \\
\text { ppl } \\
\text { ppl } \\
\text { gap } \\
\text { locale } \\
\text { cliff } \\
\text { woods } \\
\text { woods } \\
\text { ppl } \\
\text { locale } \\
\text { locale } \\
\text { ridge }\end{array}$ & $\begin{array}{l}\text { center } \\
\text { center } \\
\text { center } \\
\text { center } \\
\text { center } \\
\text { top } \\
\text { center } \\
\text { center } \\
\text { center } \\
\text { center } \\
\text { center } \\
\text { center } \\
\text { center } \\
\text { center } \\
\text { center } \\
\text { center } \\
\text { center } \\
\text { center } \\
\text { center }\end{array}$ & \\
\hline
\end{tabular}

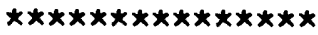

* Indicates the presence of a diacritical mark within the name.

** Developed by Geographic Names Information Management, Branch of Geographic Names, Office of Geographic Research, National Mapping Division, U. $S$. Geological Survey

$\begin{array}{clc}1,191 & \text { RECORDS PRINTED } \\ 1,191 & \text { INPUT } & \text { RECORDS } \\ 1,191 & \text { JOB } & 1\end{array}$


FEATURE

CLASS

\begin{tabular}{|c|c|}
\hline airport & Airstrip \\
\hline airport & Airfield \\
\hline airport & Airport \\
\hline airport & Landing strip \\
\hline airport & Landing FieId \\
\hline $\operatorname{arch}$ & Natural Bridge \\
\hline $\operatorname{arch}$ & Arch \\
\hline $\operatorname{arch}$ & Sea Arch \\
\hline area & Malpais \\
\hline area & L1ano \\
\hline area & Scabland \\
\hline area & Prairie \\
\hline area & Plaza (physical) \\
\hline area & Playa \\
\hline area & Reach \\
\hline area & Bahada \\
\hline area & Badlands \\
\hline area & Deep \\
\hline area & Breakers \\
\hline area & Alluvial Fan \\
\hline area & Tableland (+ $3 \mathrm{mi}$ across) \\
\hline area & Garden \\
\hline area & Fan \\
\hline area & DeIta \\
\hline area & Coteau \\
\hline area & Breaks \\
\hline area & Barrens \\
\hline area & Race \\
\hline area & Scabrock \\
\hline area & Alluvium \\
\hline area & GoldfieId \\
\hline area & Mouth \\
\hline area & Embouchure \\
\hline area & Callow \\
\hline area & Boca \\
\hline area & Highland \\
\hline area & Wasteland \\
\hline area & slang \\
\hline area & Karst \\
\hline area & Broad \\
\hline area & Deadwater \\
\hline area & Bracket \\
\hline area & stillwater \\
\hline area & Paramo \\
\hline area & Debouchure \\
\hline area & Burn \\
\hline area & PIacer \\
\hline area & Area \\
\hline area & Forest (natural) \\
\hline
\end{tabular}

SOURCE

POINT

REQ center

center

center

center

center

center

center

center

center

center

center

center

center

center

center

center

center

center

center

center

center

center

center

center

center

center

center

center

center

center

center

center

center

center

center

center

center

center

center

center

center

center

center

center

center

center

center

center

center 


\begin{tabular}{|c|c|}
\hline area & Foot \\
\hline area & Scrubland \\
\hline area & Rip \\
\hline area & Lick \\
\hline area & Fishing Ground \\
\hline area & Gravel Fan \\
\hline arroyo & Coulee \\
\hline arroyo & Draw (shallow) \\
\hline arroyo & Gulley \\
\hline arroyo & Watercourse (dry) \\
\hline arroyo & Wash \\
\hline arroyo & Sandwash \\
\hline arroyo & Drywash \\
\hline arroyo & Wadi \\
\hline arroyo & Arroyo \\
\hline bar & Spit \\
\hline bar & Ledge (water) \\
\hline bar & Sandbar \\
\hline bar & Danger \\
\hline bar & Spoil Bank \\
\hline bar & Sandbank \\
\hline bar & Foulground \\
\hline bar & Shelf \\
\hline bar & Bar \\
\hline bar & Longshore $\mathrm{Ba}$ \\
\hline bar & Lunatt \\
\hline bar & Swash \\
\hline bar & Offshore Bar \\
\hline bar & Tie \\
\hline bar & Ty ing \\
\hline bar & Waste Bank \\
\hline bar & Bank \\
\hline bar & Hook \\
\hline bar & Shoal \\
\hline bar & Reef \\
\hline bar & Rock \\
\hline basin & Depression \\
\hline basin & Pothole \\
\hline basin & Bowl \\
\hline basin & Pit \\
\hline basin & Pocket \\
\hline basin & Cirque \\
\hline basin & Amph i theater \\
\hline basin & Sink \\
\hline basin & Wallow \\
\hline $\begin{array}{l}\text { basin } \\
\text { basin }\end{array}$ & Kettle \\
\hline basin & Swallow \\
\hline basin & Water Sink \\
\hline
\end{tabular}

center center center center center center mouth mouth mouth mouth mouth mouth mouth mouth mouth center center center center center center center center center center center center center center center center center center center center center center center center center center center center center center center center center center 
FEATURE

CLASS

bas in

bas in

bas in

bas in

bas in

bas in

basin

bas in

bas in

basin

bas in

bas in

bas in

bas in

bas in

bas in

bas in

bas in

basin

bas in

bas in

bay

bay

bay

bay

bay

bay

bay

bay

bay

bay

bay

bay

bay

bay

bay

bay

bay

bay

bay

bay

bay

bay

beach

beach

beach

beach

beach

beach
GENERIC/WORD

Sinkhole

Kar

Polje

Kettlehole

Uvala

Polye

Fulje

Dolina

Catchment

Doline

Bas in

Corrie

Ponor

Graike

River Basin

Dustwell

Intervale

Caldron

Subsidence

Bolson

Quarry

Sound

Roads

Inlet (water body)

Hole (water)

Arm

Harbor (natural)

Bight

Embayment

Ria

Baie

Open Bay

Firth

Bottleneck

voe

Gulf (water)

Estuary

Water

Bay

Chuck

Cove (water)

Estero

Eddy

Coast

Strand

Shore

Coastline

Littoral

Coulter

center

center

center

center

center

center

center

center

center

center

center

center

center

center

center

center

center

center

center

center

center

center

center

center

center

center

center

center

center

center

center

center

center

center

center

center

center

center

center

center

center

center

center

center

center

center

center

center

center 
beach

beach

beach

beach

beach

beach

beach

beach

bench

bench

bench

bench

bend

bend

bend

bend

bend

bend

bend

bend

bend

bend

bend

bend

bend

bend

bend

bend

bridge

bridge

bridge

bridge

bridge

building

building

building

building

canal

canal

canal

canal

canal

canal

canal

canal

canal

canal

canal

cape
Cusp

Beach (unpopulated)

Seaboard

Foreside

Seacoast

Shingle

Shoreline

Sand

Ledge (land)

Platform

Bench

Terrace

Cutoff

oxbow

Hole (land)

E1bow

Meander

Confluence

Reentrant

River Bottom

Horseshoe

Bot

Loop

Bend

Carse

Curve

Meander Core

Bottom

Bridge

Trestle

Overpass

viaduct

Causeway

Railroad station

Building

Casa

Court House

Latera1

Drain (man-made)

Flume (man-made)

Wasteway

Aqueduct

Spillway

Acequia

sluice

Ditch

Canal

Channel (man-made)

Neck center

center

center

center

center

center

center

center

center

center

center

center

center

center

center

center

center

center

center

center

center

center

center

center

center

center

center

center

center

center

center

center

center

center

center

center

center

center

center

center

center

center

center

center

center

center

center

center

center 
FEATURE

CLASS

cape

cape

cape

cape

cape

cape

cape

cape

cape

cape

cape

cape

cape

cape

cave

cave

cave

cave

cave

cave

cave

cave

cave

cave

cave

cave

cave

cave

cave

cave

cave

cave

cemetery

cemetery

cemetery

cemetery

cemetery

channel

channel

channel

channel

channel

channel

channel

channel

channel

channel

channel

channel
GENERIC/WORD

Doab

Tongue

Bil1

Mull

Nes 5

Cap

Peninsula

Toe

Cape

Hook

Point (peninsula)

Peninsula

Top

Lae

Grotto

Cavern

Cellar

Alcove

Goe

Swallow Hole

Shake

Puragatory

Puffing Hole

$\mathrm{Niche}$

Nip

Blowhole

Cave

Sea Cave

Leach Hole

Balm

Keana

Caverns

Burying Ground

Burial

Memorial Garden

Grave

Cemetery

Stretch

Cut

Fairway

Thorofare

Midway

Cutoff

Notch

Outlet

Floodway

Thoroughfare

River Bed

Channel (natural)
SOURCE

POINT

REQ center

center

center

center

center

center

center

center

center

center

center

center

center

center

center

center

center

center

center

center

center

center

center

center

center

center

center

center

center

center

center

center

center

center

center

center

center

center

center

center

center

center

center

center

center

center

center

center

center 
FEATURE

CLASS

channel

channel

channel

channe1

channel

channel

channe1

channel

channel

church

church

church

church

church

church

church

church

church

church

church

church

church

civil

civil

civil

civil

civil

civil

civil

civil

civil

civil

civil

civil

civil

civil

civil

civil

civil

civil

civil

civil

cliff

cliff

cliff

cliff

cliff

cliff

cliff
GENERIC/WORD

Narrows

Gate

Range

Pass

Strait

Waterway

Chute

Passage (navigation)

Dugout

Tabernacle

Shrine

Pagoda

Mosque

Synagogue

Chape 1

Kirk

Meetinghouse

Monastery

Mission

Church

Capilla

Temple

City (administrative)

Town

Precinct

Parish

Plantation

Municipality

Borough

Barrio

Division

Township

District

County

Civil Division

Grant

Land Grant

Municipio *

Shire

School District

Rancho

Claim

Ceja

Buttress

Brow

Mountainside

Crag

Bluff

Head (steep face)
SOURCE

POINT

REQ center

center

center

center

center

center

center

center

center

center

center

center

center

center

center

center

center

center

center

center

center

center

center

center

center

center

center

center

center

center

center

center

center

center

center

center

center

center

center

center

center

center

center

center

center

center

center

center

center 


\section{FEATURE \\ CLASS}

cliff

cliff

cliff

cliff

cliff

cliff

cliff

cliff

cliff

cliff

cliff

cliff

cliff

cliff

cliff

cliff

cliff

cliff

cliff

cliff

cliff

cliff

cliff

cliff

cliff

cliff

cliff

cliff

crater

crater

crater

crater

crater

crater

crater

crater

dam

dam

dam

dam

dam

falls

falls

falls

falls

falls

falls

falls

flat
GENERIC/WORD

Wal1

Headland

Dalles

Precipice

Scarp

Rimrock

Escarpment

Palisades

Nose

Headwall

steephead

Falaises

Foreland

Rim

Naze

Thurm

Scaur

Winged Headland

Scar

Cliff

Overhang

Point (promontory)

Projection

Stone

Pali

Motte

Promontory

Jumpoff

Maar

Lava Pit

Monticle

Monticule

Bocca

Crater

Lua

Caldera

Dam

Sluice Gate

Mole

Breakwater

Jetty

Waterfall

Cataract

Cascade

Fall

Bridal Veil

Falls

Drop

Floor
PRIME

POINT

center

center

center

center

center

center

center

center

center

center

center

center

center

center

center

center

center

center

center

center

center

center

center

top

center

top

center

top

center

center

center

center

center

center

center

center

center

center

center

center

center

center

center

center

center

center

center

center

center 
Salturn

Salt Prairie

center

center

center

center

center

center

center

center

center

center

center

center

center

center

center

center

center

center

center

center

center

center

center

center

center

center

center

Salt Bottom

center

Wetland

Salt Flat

center

center

Flat

center

Hat

center

Thwaite

center

Fields

center

Mor

Park (natural)

center

center

Potrero

center

Tidal Flat

center

Meadow

center

National Forest

center

center

center

Reserve

center

State Forest

Forest (administrative)

center

Intercolline

center

center

center

Saddle

Puerta 
FEATURE

CLASS

\begin{tabular}{|c|c|}
\hline $\begin{array}{l}\text { gap } \\
\text { gap }\end{array}$ & $\begin{array}{l}\text { Puerto (land) } \\
\text { Notch }\end{array}$ \\
\hline gap & Pass \\
\hline gap & Water Gap \\
\hline gap & $\mathrm{Col}$ \\
\hline gap & Narrows \\
\hline gap & Portal \\
\hline gap & Constriction \\
\hline gap & Defile \\
\hline gap & Gate \\
\hline gap & Funnel \\
\hline gap & Corrider \\
\hline gap & Aisle \\
\hline gap & Swag \\
\hline gap & Thoroughfare \\
\hline gap & Gap \\
\hline gap & Wind Gap \\
\hline gap & Puerto \\
\hline gap & Puertecito \\
\hline geyser & Fountain \\
\hline geyser & Fumaroles \\
\hline geyser & Geyser \\
\hline glacier & Icefield \\
\hline glacier & Crevasse (ice) \\
\hline glacier & Icefall \\
\hline glacier & Neve $*$ \\
\hline glacier & Moulin \\
\hline glacier & Icesheet \\
\hline glacier & Icecap \\
\hline glacier & Malaspina \\
\hline glacier & Snowfield \\
\hline glacier & Firn \\
\hline glacier & Glacier \\
\hline glacier & Ice Patch \\
\hline glacier & Snow Patch \\
\hline gut & Waterway \\
\hline gut & Water Passage \\
\hline gut & Inlet (channel) \\
\hline gut & Slue (open channe1) \\
\hline gut & Tidal Creek \\
\hline gut & Gut \\
\hline gut & Tidal Inlet \\
\hline gut & Tickle \\
\hline gut & Chute \\
\hline gut & Breachway \\
\hline gut & slough (stagnant) \\
\hline gut & Bayou (stagnant) \\
\hline gut & Entrance \\
\hline gut & Thorofare \\
\hline
\end{tabular}

SOURCE

POINT

REQ

center
center
center
center
center
center
center
center
center
center
center
center
center
center
center
center
center
center
center
center
center
center
center
center
center
center
center
center
center
center
center
center
center
center
center
center
center
center
center
center
center
center
center
center
center
center
center
center
center 


\section{FEATURE}

CLASS

harbor

harbor

harbor

harbor

harbor

harbor

harbor

harbor

hospital

hospital

is land

is land

is land

is land

island

is land

is land

is land

is land

is land

is land

is land

is land

is land

is land

island

is land

is land

is land

is land

is land

is land

is land

is land

is land

island

is land

is thumus

is thmus

lake

lake

lake

lake

lake

lake

lake

lake

lake

lake
GENERIC/WORD

Waterfront

Puerto (water)

Port

Haven

Roadstead

Harbor (man-made)

Anchorage

Hono

Inf irmary

Hospital

Cayo

Archipelago

Hummock

Cay

Sandkey

Key

Isle

Cey

Lump

Towhead

Faro

Sedge

Rookery

Eyot

Skerry

Thrumc ap

Tump

Ki puka

Island ( $s$ )

Rock

Nubble

Moku

Hammock

Ato11

Islet

Barrier Island

Barrier Beach

Tombolo

Isthmus

Backwater

Bogue (still)

Banco

Waterhole (area)

Sea (inland)

Laguna

Resaca

Pool (natural)

Hole

Lac
SOURCE

POINT

REQ center

center

center

center

center

center

center

center

center

center

center

center

center

center

center

center

center

center

center

center

center

center

center

center

center

center

center

center

center

center

center

center

center

center

center

center

center

center

center

center

center

center

center

center

center

center

center

center

center 
lake

Tarn

POINT

REQ

lake

Loch

lake

lake

Loop Lake

center

Lough

Oxbow

Water Pocket

center

lake

lake

lake

lake

lake

lake

lake

lake

lake

lake

lake

lake

lava

lava

lava

lava

lava

lava

lava

lava

lava

lava

lava

lava

levee

levee

levee

levee

levee

levee

levee

levee

Waterpan

Rainpool

Finger

Sagpond

Horseshoe

Lagoon (open water)

Lake (s)

Pond (natural)

center

center

center

center

center

center

center

center

center

center

center

Slough

center

Charco

Lava Field

center

center

Steptoe

center

Lava Flow

center

Lava Cone

center

Aa

Lava Tube

center

center

center

Lava Tongue

center

Lava Plateau

center

Lava Plain

center

Lava Delta

center

Kipuka

Lava

Embankment

center

center

center

Dike

Cutbank

Levee

Revetment

Hirst

Sea Wall

Bank

locale

Picnic Area

locale

Homestead

locale

Portage

locale

Ranch

Plaza (cultural)

Sheep Camp

Summit (cultural)

center

center

center

center

center

center

center

center

center

center

center

center

center

center

Ruins

Overlook

Fairgrounds

Grange Hall

Rodeo Grounds

Railroad siding

center

center

center

center

center

center 


\section{FEATURE} CLASS

locale

locale

locale

locale

locale

locale

locale

locale

locale

locale

locale

locale

locale

locale

locale

locale

locale

locale

locale

locale

locale

locale

locale

locale

locale

locale

locale

locale

locale

locale

locale

locale

locale

locale

locale

locale

locale

locale

locale

locale

locale

locale

locale

locale

locale

locale

locale

locale

locale
GENERIC/WORD

Campground
Camp
Cabin
Battle Field
Grange
Guard Station
Crossroads
Locale (little or no population)
Store
Retreat
Exclosure
Railroad Stop
Farm
Estate
Market
Locality
Mill
Milltown
Slip
Tavern
Wayside
Pier
Furnace
Corral
Ordinary
Firetower
Marina
Shelter
Quay
Site
Plantation
Addition
Spa
Port of Entry
Lookout
Foundry
Fort
Foot
Dock
Landing
Ford
Tipple
Shop
Golf Course
Yacht Club
Downs
Research Station
Pen
Junction

center

center

center

center

center

center

center

center

center

center

center

center

center

center

center

center

center

center

center

center

center

center

center

center

center

center

center

center

center

center

center

center

center

center

center

center

center

center

center

center

center

center

center

center

center

center

center

center

center 
FEATURE

CLASS

locale

locale

locale

locale

locale

locale

locale

locale

locale

locale

locale

locale

locale

locale

locale

locale

locale

locale

locale

locale

locale

locale

locale

locale

locale

locale

locale

military

military

military

military

military

military

military

military

military

military

military

military

military

military

military

military

military

military

military

military

military

military
GENERIC/WORD

Crossing

Sports Arena

Corner

Windmil1

Forge

Recreation site

Ferry

Speedway

Ghost Town

Dairy

Battlefield

Hall

Yard

Passage (portage)

Wharf

Natatorium

Agency

Orchard

Toll House

Station (no population)

Dragway

Corners

Country Club

Inn

Lighthouse

Dockyard

siding

Amphibious Base

Weapons Range

Missile Base

Marine Corps Air station

Ammunition Depot

Ammunition Plant

Army Post

Air station

Test Range

Marine Corps Base

Firing Range

Arsenal

Military Reservation

Army Headquarters

Army Depot

Air Facility

Space Flight Center

Barracks

Missile Range

Reserve Training Center

Quartermaster Depot

Coast Guard Lifeboat station
SOURCE

POINT

REQ

center

center

center

center

center

center

center

center

center

center

center

center

center

center

center

center

center

center

center

center

center

center

center

center

center

center

center

center

center

center

center

center

center

center

center

center

center

center

center

center

center

center

center

center

center

center

center

center

center 
FEATURE

CLASS

military

military

military

military

military

military

military

military

military

military

military

mine

mine

mine

mine

mine

mine

mine

oilfield

oilfield

park

park

park

park

park

park

park

park

park

park

park

park

park

park

park

park

park

park

park

pass

peak

pillar

pillar

pillar

pillar

pillar

pillar

pillar

pillar
GENERIC/WORD

Supply Center

Coast Guard Base

Test Center

Supply Depot

Ordnance Laboratory

Firing Center

Naval Shipyard

Ordnance Plant

Naval Air Station

Naval Base

Air Force Base

Shaft

Pit

Gloryhole

Quarry

Portal

Mine

Adit

Oil Pumping Station

Oilfield

National Historical Landmark

Game Management Area

National Wildlife Area

National Seashore

National Wilderness Area

National Monument

National Park (administrative)

Reserve

Game Reserve

Sanc tuary

Cairn

Common

Arboretum

State Park

Square

Field

Park (Administrative)

Refuge

Monument

Narrow

Ben

Penasco *

Pena *

Pillar

Stack

Pinnacle

Rock (singular)

Monument

Needle center

center

center

center

center

center

center

center

center

center

center

center

center

center

center

center

center

center

center

center

center

center

center

center

center

center

center

center

center

center

center

center

center

center

center

center

center

center

center

center

top

top

top

top

top

top

top

top

top 
FEATURE

CLASS

\begin{tabular}{|c|c|}
\hline $\begin{array}{l}\text { pillar } \\
\text { pillar }\end{array}$ & $\begin{array}{l}\text { Spire } \\
\text { Monolith }\end{array}$ \\
\hline pillar & $\begin{array}{l}\text { Monolitn } \\
\text { Column }\end{array}$ \\
\hline pillar & Finger \\
\hline pillar & Candelas \\
\hline pillar & Pohaku \\
\hline pillar & Rock Tower \\
\hline pillar & Sea Mount \\
\hline pillar & Thumb \\
\hline pillar & Demoiselles \\
\hline pillar & Aiguille \\
\hline pillar & Tooth \\
\hline pillar & Cas \\
\hline pillar & Tepee \\
\hline pillar & Castle \\
\hline pillar & Aquafact \\
\hline pillar & Tower $(-500 \mathrm{ft}$ across $)$ \\
\hline pillar & Chimney \\
\hline plain & Grassland \\
\hline plain & Upland \\
\hline plain & Peneplain \\
\hline plain & Savanna \\
\hline plain & Terrain \\
\hline plain & Terrane \\
\hline plain & Terrene \\
\hline plain & Pampas \\
\hline plain & Tundra \\
\hline plain & Karroo \\
\hline plain & steppe \\
\hline plain & Erg \\
\hline plain & Hamada \\
\hline plain & $\operatorname{Reg}$ \\
\hline plain & Plain \\
\hline plain & Champaign \\
\hline plain & Campagna \\
\hline plain & Desert \\
\hline plain & Kula \\
\hline plain & Veldt \\
\hline plain & Outwash \\
\hline plain & Panplain \\
\hline plain & Plat \\
\hline plain & Lea \\
\hline plain & Plains \\
\hline plain & Plateau \\
\hline ppl & Resort \\
\hline pp1 & City (populated place) \\
\hline ppl & Town (populated place) \\
\hline $\mathrm{ppl}$ & PPL (Populated Place) \\
\hline ppl & Settlement \\
\hline
\end{tabular}

SOURCE $\begin{array}{lc}\text { PRIME } & \text { POINT } \\ \text { POINT } & \text { REQ }\end{array}$

$\begin{array}{lc}\text { PRIME } & \text { POINT } \\ \text { POINT } & \text { REQ }\end{array}$

top

top

top

top

top

center

center

top

top

top

top

top

top

top

top

top

top

top

center

center

center

center

center

center

center

center

center

center

center

center

center

center

center

center

center

center

center

center

center

center

center

center

center

center

center

center

center

center

center 
FEATURE

CLASS

\begin{tabular}{ll} 
ppl & Borough \\
ppl & Port \\
ppl & Commity \\
ppl & Suburb \\
ppl & Beach (populated) \\
ppl & Silo \\
ppl & Plantation \\
ppl & Hamlet \\
ppl & Bury \\
ppl & Bur \\
ppl & Burg \\
ppl & Burgh \\
ppl & Chester \\
ppl & Caster \\
ppl & Ham \\
ppl & Hamp \\
ppl & Corner \\
ppl & Stead \\
ppl & Sted \\
ppl & Boro \\
ppl & Cester \\
ppl & Beigh \\
ppl & Tin \\
ppl & Ton \\
ppl & Village \\
ppl & Ten \\
ppl & By \\
ppl & Wich \\
ppl & Thorpe \\
ppl & Tun \\
ppl & Station (populated) \\
pp1 & Worth \\
ppl & Wick \\
range & Cordillera \\
range & Mountain Range \\
range & Hills \\
range & Chain \\
range & Mountain Chain \\
range & Massif \\
range & Sawback \\
range & Sierra \\
range & Mountain System \\
range & Mountain Group \\
range & Paramilla \\
range & Mountains \\
range & Range \\
rapids & Ripple \\
rapids & Rapids \\
rapids & Rifle \\
& \\
\hline &
\end{tabular}

center

center

center

center

center

center

center

center

center

center

center

center

center

center

center

center

center

center

center

center

center

center

center

center

center

center

center

center

center

center

center

center

center

center

center

center

center

center

center

center

center

center

center

center

center

center

center

center

center 


\section{FEATURE}

CLASS

rapids

rapids

rapids

rapids

rapids

rapids

reserve

reserve

reservoir

reservoir

reservoir

reservoir

reservoir

reservoir

reservoir

reservoir

reservoir

reservoir

reservoir

reservoir

reservoir

ridge

ridge

ridge

ridge

ridge

ridge

ridge

ridge

ridge

ridge

ridge

ridge

ridge

ridge

ridge

ridge

ridge

ridge

ridge

ridge

ridge

ridge

ridge

ridge

ridge

ridge

ridge

ridge
GENERIC/WORD

Eddy

Whirlpool

Overfall

Torrent

Rips

Sault

Indian Reservation

Reserve

Watertank

Millpond

Cistern

Flowage

Tank

Pool (man-made)

Flooding

Reservoir

Pozo

Pond (man-made)

Retention Basin

Tanque

Cachment

Hogback

Crest (1 inear)

Cuesta

Esker

Rough

Hoodoos

Lead

Balk

Ball

Razorback

Saddleback

Os

Osar

Backbone

Moraine (1inear)

Berm

Watershed

Salient

Horseback

Spur

Ridge

Reef

Galera

Sowback

offset

Lae

Comb

Morriner
SOURCE

POINT

REQ center

center

center

center

center

center

center

center

dam

dam

center

center

dam

dam

dam

dam

center

dam

center

center

center

center

center

center

center

center

center

center

center

center

center

center

center

center

center

center

center

center

center

center

center

center

center

center

center

center

center

center

center 
center

ridge

Narrows

center

ridge

Divide

ridge

Arete *

center

ridge

Point

ridge

Yardang

center

center

school

Campus

center

school

Academy

center

school

College

center

University

center

school

school

school

school

school

sea

sea

sea

sea

High School

center

School

center

Institute

School

Sea (continental)

center

center

center

center

Ocean

center

Mer

center

Mar

shoal

Ground

center

center

Pitch

center

Landslip

center

Shoulder

center

Scree

Rock slide

center

center

Pediment

Declivity

center

center

slide

Lands lide

center

center

Adert

Gradient

Talus

Acclivity

center

center

center

center

Descent

center

Ranch

Mudflow

Rockfall

Glacis

slope

Upbac

Versant

Landfall

Grade

Cove

Oasis

Waterhole (point)

center

center

center

center

center

center

center

center

center

center

center

center

center

Seep

Hot Spring

center

Mud Pot

ojito

center

center 
spring

spring

spring

stream

stream

stream

stream

stream

stream

stream

stream

stream

stream

stream

stream

stream

stream

stream

stream

stream

stream

stream

stream

stream

stream

stream

stream

stream

stream

stream

stream

stream

stream

stream

stream

stream

stream

stream

stream

stream

stream

stream

stream

stream

stream

stream

stream

stream

stream
Spring

ojo

Springs

Watercourse (flowing)

Cala

Kill

Bourne

Runne1

Rill

Rio

Prong

Drain (natural)

Current

Rivulet

Bogue (flowing)

Chute

Caleta

Riviere *

Burn

Anabranch

Stream

Feeder

Riveret

Swamp

Headwaters

v1y

Throat

River

Brook

Tiderace

stringer

Foso

Freshet

Fosse

Bayou (flowing)

Estero

Trace

Pup

Awawa

Creek

Agua

Fork

Branch

Distributary

slough (flowing)

Run

Inlet

slash

outlet
PRIME

POINT

POINT

REQ

center

center

center

mouth

mouth

yes

mouth

yes

yes

yes

yes

yes

yes

yes

yes

yes

yes

yes

yes

yes

yes

yes

yes

yes

yes

yes

yes

yes

yes

yes

yes

yes

yes

yes

yes

yes

yes

yes

yes

yes

yes

yes

yes

yes

yes

yes

yes

yes

yes

yes

yes

yes 
FEATURE

CLASS

stream

stream

stream

stream

stream

stream

stream

summit

summit

summit

summit

summit

summit

summit

summit

summit

summit

summit

summit

summit

summit

summit

summit

summit

summit

summit

summit

summit

summit

summit

summit

summit

summit

summit

summit

summit

summit

summit

summit

summit

summit

summit

summit

summit

summit

summit

summit

summit

summit
GENERIC/WORD

Race

F1y

Rito

Brake

Tributary

Lick

Cam

Drumloid

Hillock

Boulder

Cerrillo

Bolly

Drumlinoid

Sea stack

Drum

Bald

Serrate

Cerro

Fill

Roche Moutonnee

Cerrito

Fold

Foredune

Collado

Cone

Medano

Colina

Mass

Butte

Berg

Colline

Bally

Cumbre

Crest (top)

Dome

Alto

Monadnock

Nobble

Hill

Head (hill)

Teton

Lenticular

Remnant

Huerfano

Rock (massive)

Sandia

Kernbut

Drift

Baraboo
SOURCE

POINT

REQ

$\begin{array}{ll}\text { mouth } & \text { yes } \\ \text { mouth } & \text { yes } \\ \text { mouth } & \text { yes } \\ \text { mouth } & \text { yes } \\ \text { mouth } & \text { yes } \\ \text { mouth } & \text { yes } \\ \text { mouth } & \text { yes }\end{array}$

top

top

top

top

top

top

top

top

top

top

top

top

top

top

top

top

top

top

top

top

top

top

top

top

top

top

top

top

top

top

top

top

top

top

top

top

top

top

top

top

top

top 
FEATURE

CLASS

summit

summit

summit

summit

summit

summit

summit

summit

summit

summit

summit

summit

summit

summit

summit

summit

summit

summ it

summit

summit

summit

summit

summ it

summit

summit

summit

summit

summit

summit

summit

summit

summit

summit

summit

summit

summit

summit

summit

summit

summit

summit

summit

summit

summit

summit

summit

summit

summit

summit
GENERIC/WORD

PRIME

POINT

SOURCE

POINT

REQ top

top

top

top

top

top

top

top

top

top

top

top

top

top

top

top

top

top

top

top

top

top

top

top

top

top

top

top

top

top

top

top

top

top

top

top

top

top

top

top

top

top

top

top

top

top

top

top

top 
FEATURE

CLASS

summit

summit

summit

summit

summit

summit

summ it

summ it

summit

sumnit

sumnit

summit

summit

sumn it

summit

summit

summit

summ it

summit

summit

summit

summit

summit

summit

summit

summit

summit

summit

summit

summit

swamp

swamp

swamp

swamp

swamp

swamp

swamp

swamp

swamp

swamp

swamp

swamp

swamp

swamp

swamp

swamp

swamp

swamp

swamp
GENERIC/WORD

Butt

Eminence

Punta

Motte

Baldy

Sheepback

Tor

Volcano

Sand Drift

Mountain

Whaleback

Cinder

Mud Cone

Monte

Loma

Tower $(+500 \mathrm{ft}$. across)

Sugar Loaf

Hum

Mauna

Hamongog

Puu

Solfatara

Hurst

Mont

Pico

Rognon

Bray

Dun

Mott

Head

Slue (not open channel)

Tarai

Bogan

Floodplain

Tidal Marsh

Interfluve

Deadening

Mareman

Lowmoor

Marsh

Swamp

Baygul

Marais

Logan

Dismal

Pocosin

Quagmire

Slash

Mangrove
PRIME

POINT

SOURCE

POINT

REQ top

top

top

top

top

top

top

top

top

top

top

top

top

top

top

top

top

top

top

top

top

top

top

top

top

top

top

top

top

top

center

center

center

center

center

center

center

center

center

center

center

center

center

center

center

center

center

center

center 
swamp

swamp

swamp

swamp

swamp

swamp

swamp

swamp

swamp

swamp

swamp

swamp

swamp

swamp

swamp

swamp

swamp

swamp

swamp

swamp

swamp

swamp

swamp

tower

tower

trail

trail

trail

trail

trail

trail

trail

trail

tunnel

tunnel

valley

valley

valley

valley

valley

valley

valley

valley

valley

valley

valley

valley

valley

valley

Mire

Fly

Intervale

Morais

Quaking Bay

Moremma

Bog

Morass

Fen

Muskeg

Cienaga

Flatwoods

Everglade

Brake

Strand

v1y

Suck

Heath

Tule

Tulelands

Baygall

Sedge

Lagoon (vegetation)

Beacon

Tower

Trace

Trail

Ski Trail

Stock Trail

PRIME

POINT

POINT

REQ

center

center

center

center

center

center

center

center

center

center

center

center

center

center

center

center

center

center

center

center

center

center

center

center

center

center

center

center

center

Spur

center

Path

Track

Jeep Trail

center

center

Tunnel

center

Portal

center

Flume (natural)

center

Fiord

Draw (deep)

Dingle

Dale

Graben

Chasm

Couloir

Cleugh

Furrow

Gil1

Barranca

Do1

Box Canyon

mouth

yes

mouth

yes

mouth

yes

mouth

yes

mouth

yes

mouth

yes

mouth

yes

mouth

yes

mouth

yes

mouth

yes

mouth

yes

mouth

yes

mouth

yes

mouth

yes 
FEATURE
CLASS

valley

valley

valley

valley

valley

valley

valley

valley

valley

valley

valley

valley

valley

valley

valley

valley

valley

valley

valley

valley

valley

valley

valley

valley

valley

valley

valley

valley

valley

valley

valley

valley

valley

valley

valley

valley

valley

valley

valley

valley

valley

valley

valley

valley

valley

valley

valley

valley

well
River Valley

Nullah

Clove

Cleft

Donga

Cleuch

Backdeep

vley

De11

Crevasse (earth)

Vlei

v1y

Vale

Trough

Trench

Swale

Canada *

Canon *

Cluse

Mofette

Transverse

Thalweg

Quebrada

Cajon

Fissure

Fault

Draft

Rift

Hole

Jambs

Hollow

Rincon

Wash

Gulf (1 and)

Gulch

valley

Gully

Coulee

Chine

Coombe

Cove (land)

Ravine

Canyon

Valle

Box

Combe

Ramble

Cumb

Well mouth

yes

mouth

mouth

mouth

mouth

mouth

mouth

mouth

mouth

mouth

mouth

mouth

Mouth

mouth

mouth

mouth

mouth

mouth

mouth

mouth

mouth

mouth

mouth

mouth

mouth

mouth

mouth

mouth

mouth

mouth

mouth

mouth

mouth

mouth

mouth

mouth

prime

mouth

mouth

mouth

mouth

mouth

mouth

mouth

mouth

mouth

mouth

mouth

center yes

yes

yes

yes

yes

yes

yes

yes

yes

yes

yes

yes

yes

yes

yes

yes

yes

yes

yes

yes

yes

yes

yes

yes

yes

yes

yes

yes

yes

yes

yes

yes

yes

yes

yes

yes

yes

yes

yes

yes

yes

yes

yes

yes

yes

yes

yes 
FEATURE

CLASS

we11

well

woods

woods

woods

woods

woods

woods

woods

woods

woods

woods
GENERIC/WORD

Oilwell

Borehole

Thicket

Taiga

Silva

Shaw

Woods

Mott

Brake

Grove

Woodland

Scrub
SOURCE

POINT

REQ
POINT

center

center

center

center

center

center

center

center

center

center

center

center

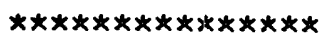

* Indicates the presence of a diacritical mark within the name.

* Developed by Geographic Names Information Management, Branch of Geographic Names, Office of Geographic Research, National Mapping Division, U. $S$. Geological Survey 


\section{GLOSSARY OF TERMS}

annotated bibliography - A complete bibliographic reference including a short explanation and worth of the source.

areal feature - Features that contain area as opposed to those that are classed as linear; the coordinates "digitized" or recorded are at the approximate center of the feature.

bathymetric - The measurement of the depth of a water body, hence, a map with isobaths or contour lines measuring the relief of the floor of the body of water.

Board on Geographic Names - See U.S. Board on Geographic Names.

cell - Used specifically in GNIS to refer to equal 7.5-by 7.5-minute map areas. The term is used because GNIS references the map cell whether published or not published, and divides "overedge" maps into two equal 7.5-minute by 7.5-minute maps.

centroid - The approximate center of an areal feature and the point represented by the primary geographic coordinate.

CNR - See Domestic Geographic Names Report

controlled redundancy - Multiple occurrence of data or records on purpose. For example, a name entity passing through or occuring in more than one State has a valid record in each state file in which it is located.

Controversial Name Report - See Domestic Geographic Names Report

data base - A collection of interrelated or independent data items stored together without unnecessary redundancy, to serve one or more applications.

data element - A basic unit of identifiable and definable information and occupies the space provided by fields in a record, blocks, or a form.

data item - An expression of a fact of a data element. A subdivision of the data element, and the smallest definable unit in a record.

data system - A collection of data bases.

designator - See feature class.

diacritical mark - A mark added to a letter to show pronunciation. Domestic Geographic Names Report - The form used to annotate and submit controversial names to the U.S. Board on Geographic Names for resolution. entity - Something about which data are recorded. In data base management concepts, a person, place, or object about which items or data are collected, recorded, and organized into fields, records, and data files.

feature-class - One of 62 broad categories in GNIS that groups similar features into categories to facilitate search and retrieval. For example, creek, river, branch, brook, run, etc., are all linear overland flowing bodies of water categorized as streams.

feature class definition - The specific definition of 62 broad GNIS categories of features.

Federal Information Processing Standards (FIPS) Code - Any code developed and published by the National Bureau of Standards; specifically, in GNIS, the five-digit numeric state/county codes and certain twocharacter alphabetical codes for foreign countries.

field - See data element.

FIPS Code - See Federal Information Processing Standards Code. generic - That part of a geographic name that refers to kind or type of feature. For example, Big lake where lake is the generic part of the name. 
geographic coordinates - An artificial system or grid expressed in degrees, minutes, and seconds used for location on the Earth's surface latitude measures distance north-south and longitude measures distance east-west.

geographic name - A proper name or geographic expression by which a particular geographic entity is or was known; a noun phrase of one or more words used consistently in spoken and (or) written language to refer to a particular and relatively permanent place, feature, or area on the Earth's surface or to a conceptionally related group of such places, features or area.

Geographic Names Information System (GNIS) - The system composed of data bases, software, programs, and procedures that include geographic names, their standards, and associated information.

GNIS - An acronym for Geographic Names Information System.

interactive - The process of interacting or interfacing directly with the data base for immediately retrieving and displaying information.

interface - A common boundary at which two separate systems or portions of each system join or intersect. An interface can be mechanical, as in adjoining hardware surfaces, or it can be electrical, as in single-level transformation points. Moreover, it can also refer to human and machine interface, and the interaction between man and computers.

label - The established abbreviation for each data element which must be used when establishing the search criteria.

linear feature - A named feature in GNIS that is linear rather than areal in extent. Specifically features that are in the feature categories arroyo, valley, and stream that are linear and require both mouth and source geographic coordinates.

Phase I - Includes the compilation and edit of all names in the United States and its territories from the U.S. Geological survey topographic map series (see Appendix A).

Phase II - Includes the compilation and edit of names from most known sources in addition to U.S. Geological Survey topographic maps (see Appendix A.)

primary coordinate - The geographic coordinate representing the center of areal features and the mouth of linear features.

record - A group of related data elements or fields treated as a unit specifically, a record refers to a named feature and associated data. redundancy - See controlled redundancy.

secondary coordinate - A geographic coordinate that associates a feature with each 7.5-minute U.S. Geological survey topographic map on which it is located.

software - Computer programs, procedures, rules, and documentation associated with the operation of a computer system.

source coordinate - The beginning point of linear features expressed as a geographic coordinate.

spatial - Refers to space or occupying space.

topographic map - A map portraying horizontal and vertical positions on a specific part of the Earth's surface determined by geographic coordinates and specifically portraying elevation or altitude by isohypse or contour lines. 
U.S. Board on Geographic Names - A Federal body which is authorized by law to establish and maintain uniform geographic names usage throughout the Federal Government. The Board, composed of representatives of Federal agencies, was created in 1890 and organized in its present form by Public Law in 1947.

variant - The term used to 1 ist and describe any other known names, forms or spellings of a current official name.

๘U.S. GOVERNMENT PRINTING OFFICE: $\quad 1984-461-431 / 10082$ 

